3 Prasad Prakash Patel $^{1 *}$, Prashanth Jampani Hanumantha ${ }^{2}$, Oleg I. Velikokhatnyi ${ }^{2,3}$, Moni 4 Kanchan Datta ${ }^{2,3}$, Bharat Gattu', James A. Poston ${ }^{4}$, Ayyakkannu Manivannan ${ }^{4}$, Prashant N. $5 \quad$ Kumta $^{1,2,3,5,6}$

$6{ }^{1}$ Department of Chemical and Petroleum Engineering, Swanson School of Engineering, 7 University of Pittsburgh, Pittsburgh, PA 15261, USA.

$8{ }^{2}$ Department of Bioengineering, Swanson School of Engineering, University of Pittsburgh, 9 Pittsburgh, PA 15261, USA.

$10{ }^{3}$ Center for Complex Engineered Multifunctional Materials, University of Pittsburgh, PA 15261, 11 USA.

$12{ }^{4}$ US Department of Energy, National Energy Technology Laboratory, Morgantown, WV 26507.

$13{ }^{5}$ Mechanical Engineering and Materials Science, Swanson School of Engineering, University of 14 Pittsburgh, Pittsburgh, PA 15261, USA.

$15{ }^{6}$ School of Dental Medicine, University of Pittsburgh, PA 15217, USA.

16

17 * Corresponding author: Prasad Patel (ppp4@pitt.edu)

18

19

20

21

22
Department of Chemical \& Petroleum Engineering, 818 Benedum Hall, 3700 O'Hara Street, Pittsburgh, PA 15261.

Tel: +1-303-475-2411, Fax: +1-412-624-3699

\section{hydrogen generation by Photoelectrochemical Water Splitting}




\section{Abstract:}

24 Hydrogen generation from photoelectrochemical (PEC) water splitting is on the forefront of 25 clean energy generation landscape. The efficiency of PEC system is dependent on the 26 engineering of semiconductors with tailored narrow band gap coupled with superior 27 photoelectrochemical activity and desired stability vital for the commercialization of PEC water 28 splitting cells. We report herein the study of vertically aligned $\mathrm{Nb}$ and $\mathrm{N}$ doped $\mathrm{SnO}_{2}$ nanotubes 29 (NTs), .i.e., $\left(\mathrm{Sn}_{0.95} \mathrm{Nb}_{0.05}\right) \mathrm{O}_{2}: \mathrm{N}$ NTs for PEC water splitting. $\left(\mathrm{Sn}_{0.95} \mathrm{Nb}_{0.05}\right) \mathrm{O}_{2} \mathrm{NTs}$ was selected 30 for co-doping with nitrogen by systematic analysis of applied bias photon-to-current efficiency 31 of various $\mathrm{Nb}$ doped $\mathrm{SnO}_{2} \quad(\mathrm{x}=0-0.1)$ compositions. Consequently, excellent 32 photoelectrochemical stability and the highest efficiency of $4.1 \%$ is obtained for $33\left(\mathrm{Sn}_{0.95} \mathrm{Nb}_{0.05}\right) \mathrm{O}_{2}: \mathrm{N}-600 \mathrm{NTs}$ never observed for other known $\mathrm{TiO}_{2}, \mathrm{ZnO}$, and $\mathrm{Fe}_{2} \mathrm{O}_{3}$ systems to 34 date. Additionally, theoretical first principles study provides understanding of $\mathrm{Nb}$ and $\mathrm{N}$ co35 doping on the electronic structure and band gap of $\mathrm{SnO}_{2}$ semiconductor, further corroborating 36 results of experimental study.

\section{Keywords:}

Photoelectrochemical water splitting, nanotubes, tin oxide, doped metal oxide, nitrogen doping

\section{Introduction}

Clean renewable energy generation is quintessential for the sustainable development of

44 fueling the present energy driven economy (primarily carbon based fuels) are expected to run out 45 by the year 2200.[1] Thus the impetus for switching to non-carbon based renewable energy 
46 sources. This motivation is further hastened by the seemingly irreversible anthropogenic

47 alteration of the earth's climate resulting in the global eco-system alteration threatening the

48 extinction of myriad species, amphibious, aerial as well as terrestrial.[2,3] Currently, the global

49 energy demand is being addressed on an industrial scale by the combustion of carbonaceous

50 fossil fuels. However, this approach is not sustainable as it has deleterious effects on the

51 environment unfortunately, due to excessive greenhouse gas emissions, which has necessitated

52 the identification of non-carbonaceous fuel, capable of meeting the future global energy

53 demand.[4-9] This fuel should be easy to store, handle, transport and more importantly,

54 economical to produce. In consideration of all of these aspects, hydrogen has been identified as

55 the most promising energy source replacing Gasoline, on the grounds of its high energy density

56 (120 MJ kg-1 for $\mathrm{H}_{2}$ higher than $44.4 \mathrm{MJ} \mathrm{kg}^{-1}$ for Gasoline) and environmentally benign nature

57 (low carbon footprint).[6-8, 10-16] However, there are many roadblocks for commercializing

58 hydrogen as a fuel. These include not only economic production and storage but also efficient

59 distribution of hydrogen all of which pose major challenges.

At present, hydrogen is produced on an industrial scale by steam reforming of natural

61 gas.[7, 10, 14] Other widely used methods for hydrogen production include partial oxidation of

62 hydrocarbons and coal gasification. The drawbacks of these processes are the high operating

63 temperature $\left(700^{\circ} \mathrm{C}-1000^{\circ} \mathrm{C}\right)$ and production of $\mathrm{CO}_{2}$-undesired greenhouse pollutant. $[7,10,14]$

64 Hence, alternate technology involving the use of clean fuel (low carbon footprint), low operating

65 temperature without any greenhouse gas emissions and toxic/corrosive byproduct should be

66 employed for efficient and economic production of hydrogen.[13] 
A promising and environmentally benign approach for the generation of hydrogen is the splitting of water. This approach has received significant attention, as it does not involve any greenhouse gas emissions and moreover, any corrosive byproduct.

$$
\mathrm{H}_{2} \mathrm{O}_{\text {(liq) }}+1.23 \mathrm{eV} \rightarrow \mathrm{H}_{2 \text { (gas) }}+1 / 2 \mathrm{O}_{2 \text { (gas) }}
$$

71 However, splitting of water for $\mathrm{H}_{2}$ production is associated with a major activation energy

72 barrier, requiring external energy $\left(\Delta \mathrm{G}^{\mathrm{O}}=237.13 \mathrm{~kJ} \mathrm{~mol}^{-1}\right)$.[17] To overcome this activation

73 barrier, the utilization of solar energy delivering an energy of 120,000 TW per year to the surface

74 of the earth alone[18, 19] for splitting water has received special interest.[5, 13] The 75 deconcentrated, ubiquitous, and illimitable solar energy has been thus considered as an economic 76 and viable natural energy source for a long time now, and can be utilized as an external energy 77 source for the water splitting. Solar energy induced water splitting, alternatively also known as 78 photoelectrochemical water splitting, .i.e., PEC water splitting is considered to be an attractive 79 and environmentally benign approach primarily because it involves production of hydrogen 80 driven by the electricity produced from the absorption of solar energy resulting in the production 81 of mobile charge carriers by a suitable semiconductor material.[16] Fujishima and Honda's 82 pioneering work on $\mathrm{PEC}$ water splitting using n-type $\mathrm{TiO}_{2}$ semiconductor has demonstrated for 83 the first time that PEC water splitting using semiconductor material is indeed a promising 84 approach for the production of hydrogen in an environmentally friendly manner.[13, 20] The commercialization of PEC water splitting systems as an industrial process for the 86 production of hydrogen has been largely hindered by the scarcity of an ideal semiconductor 87 material exhibiting excellent absorption of light in the visible region of interest, excellent PEC 88 stability for long term operation and high photoelectrochemical activity.[21, 22] A major part of 
the solar spectrum consists of visible light ( $46 \%)$ and $\sim 4 \%$ of UV radiation.[13] Hence, it is important to develop semiconductor materials with superior capability for visible light absorption. The ideal semiconductor material, which can be used as photoanode in PEC water splitting, should exhibit narrow band gap $\left(1.23 \mathrm{eV}<\mathrm{E}_{\mathrm{g}}<3 \mathrm{eV}\right)$, high electrical conductivity, and the correct band structure such that oxidation $(1.23 \mathrm{~V})$ and reduction potential of water $(0 \mathrm{~V})$ lie within the band gap of the material.[13] Thus far, extensive work has been conducted on metal oxide semiconductors such as $\mathrm{TiO}_{2}, \mathrm{ZnO}$ and $\mathrm{Fe}_{2} \mathrm{O}_{3}$, mainly due to their low cost and ease of availability.[7, 12, 21, 23-32] The wide band gap of $\mathrm{TiO}_{2}(\sim 3.2 \mathrm{eV})$ is one of the major constraints for its use as a photoanode in the commercialization of PEC water splitting cells.[3336] The photocatalytic activity of $\mathrm{Fe}_{2} \mathrm{O}_{3}$ is also limited by the short lifetime and diffusion length of the photogenerated carriers, high resistivity, low electron mobility and high recombination rate of photo-generated charge carriers $[37,38]$ Also, the photoelectrochemical activity of $\mathrm{ZnO}$ is limited by poor light absorption in the visible region of interest due to the wide band gap $(\sim 3.2$ $\mathrm{eV}$ ) and poor long term stability in the aqueous electrolyte solution.[39] Hence, there is a need to develop a novel semiconductor material, which will satisfy the criteria mentioned above for the ideal semiconductor material.

In addition to $\mathrm{TiO}_{2}, \mathrm{ZnO}$ and $\mathrm{Fe}_{2} \mathrm{O}_{3}, \mathrm{SnO}_{2}$ is also a promising semiconductor, widely explored in dye sensitized solar cells (DSSCs) and as a transparent conducting oxide (TCO). It has good electron mobility and is highly corrosion resistant in the acidic electrolyte solution.[4042] The electron mobility of $\mathrm{SnO}_{2}\left(\sim 100-200 \mathrm{~cm}^{2} \mathrm{~V}^{-1} \mathrm{~s}^{-1}\right)$ is also orders of magnitude higher than that of $\mathrm{TiO}_{2}\left(\sim 10^{-1} \mathrm{~cm}^{2} \mathrm{~V}^{-1} \mathrm{~s}^{-1}\right) .[43,44]$ The superior electron mobility is expected to help in fast electron transport from the semiconductor material to the current collector for $\mathrm{SnO}_{2}$.[44] However, similar to $\mathrm{ZnO}, \mathrm{SnO}_{2}$ also has a wide band gap of $\sim 3.5 \mathrm{eV}[45]$, as a result of which 
112 reports on the use of $\mathrm{SnO}_{2}$ as a photoanode for PEC water splitting are scant apart from reports

113 on band gap engineering of $\mathrm{SnO}_{2}$ by design of hesterstructures of $\mathrm{SnO}_{2} / \mathrm{TiO}_{2} / \mathrm{CdS}, \mathrm{SnO}_{2} / \mathrm{CdS}$ and

$114 \mathrm{SnO}_{2} / \mathrm{TiO}_{2}$ [46-49]. Use of $\mathrm{SnO}_{2}$ as a photoanode for PEC water splitting thus necessitates

115 systematic band gap engineering by suitable doping for improving the photoelectrochemical

116 activity of $\mathrm{SnO}_{2}$. This approach will help in lowering the band gap energy of $\mathrm{SnO}_{2}$ offering

117 improved light absorption, which is extremely important for its use as semiconductor material in

118 PEC water splitting.

Niobium is a well-studied dopant for $\mathrm{SnO}_{2}$ for use in TCO applications mainly to improve

120 the electrical conductivity of $\mathrm{SnO}_{2} \cdot[50-53]$ Niobium is considered as an effective dopant due to

121 its abundant electronic states and minor influence on $\mathrm{SnO}_{2}$ lattice structure, due to the lower

122 ionic radii of $\mathrm{Nb}^{4+}(69 \mathrm{pm})$ compared to $\mathrm{Sn}^{4+}(71 \mathrm{pm})$, resulting in minimum lattice strain.[54,

123 55] The doping of $\mathrm{Nb}$ in $\mathrm{SnO}_{2}$ is expected to introduce additional electronic states of $\mathrm{Nb}$ in the

124 band gap of $\mathrm{SnO}_{2}$, thus reducing the band gap of $\mathrm{SnO}_{2}$. The wide band gap of $\mathrm{SnO}_{2}$ is mainly

125 due to the deep location of the valence band position (O 2p orbital) at high potential.[17] This

126 issue can be addressed by the systematic upward shift of the valence band, without affecting the

127 position of the conduction band that can be achieved by the introduction of a suitable dopant

128 modifying accordingly the $\mathrm{SnO}_{2}$ electronic structure. In this study thus keeping in line with the

129 above analysis, nitrogen is also used in combination with niobium as a co-dopant for $\mathrm{SnO}_{2}$. Since

$130 \mathrm{~N} 2 \mathrm{p}$ orbitals have higher potential energy than $\mathrm{O} 2 \mathrm{p}$ orbitals, introduction of $\mathrm{N}$ in $\mathrm{SnO}_{2}$ can offer

131 hybridization of substitutional $\mathrm{N} 2 \mathrm{p}$ states with $\mathrm{O} 2 \mathrm{p}$ states causing a shift in the valence band

132 (i.e. highest occupied molecular orbital, HOMO) upwards, without affecting the conduction band 133 (i.e. lowest unoccupied molecular orbital, LUMO)[7], thereby, reducing the band gap and 134 improving the light absorption.[17, 56-59] The physical morphology and orientation of the 
nanostructure of doped $\mathrm{SnO}_{2}$ is important as it affects the charge transport in the oxide. The vertical orientation of nanostructure has received special attention as it offers high surface area which provides large area for electrolyte-electrode contact and an efficient path for transport of photogenerated carriers in the material.[60-62]

In this context, we report herein the photoelectrochemical performance of vertically aligned nanotubes of $\mathrm{Nb}$ and $\mathrm{N}$ doped $\mathrm{SnO}_{2}$, denoted as $\left(\mathrm{Sn}_{1-\mathrm{x}} \mathrm{Nb}_{\mathrm{x}}\right) \mathrm{O}_{2}: \mathrm{N}$ VANTs, as potential photoanodes or semiconductor materials. The identification of an optimized concentration of dopants is important for tailoring the band structure of $\mathrm{SnO}_{2}$. Though a high concentration of dopant is desired, as it is expected to offer reduction in the band gap and thus, improved light absorption, the additional dopant induced electronic states introduced in $\mathrm{SnO}_{2}$ can act as recombination sites for the photogenerated electron-hole pairs, resulting in poor PEC performance and low applied bias photon-to-current efficiency (ABPE), in comparison to pure $\mathrm{SnO}_{2}$. [56, 63] Hence, in this study, first, various compositions of $\mathrm{Nb}$ doped $\mathrm{SnO}_{2}$ VANTs, i.e., $\left(\mathrm{Sn}_{1-\mathrm{x}} \mathrm{Nb}_{\mathrm{x}}\right) \mathrm{O}_{2}$ VANTs $(\mathrm{x}=0,0.05,0.1)$ were synthesized using $\mathrm{ZnO}$ nanowires $(\mathrm{NWs})$ as a sacrificial template[64, 65] and their photoelectrochemical activity was assessed to select a composition exhibiting superior ABPE. The photoelectrochemical activity of the selected composition of $\left(\mathrm{Sn}_{0.95} \mathrm{Nb}_{0.05}\right) \mathrm{O}_{2}$ VANTs was then further improved by $\mathrm{N}$-doping, which was achieved by heat treatment in $\mathrm{NH}_{3}$ atmosphere at different temperatures of $400^{\circ} \mathrm{C}, 500^{\circ} \mathrm{C}, 600^{\circ} \mathrm{C}$ and $700^{\circ} \mathrm{C}$, respectively. The heat treatment was carried out at different temperatures, in order, to study the effect of concentration of nitrogen co-doped into $\left(\mathrm{Sn}_{0.95} \mathrm{Nb}_{0.05}\right) \mathrm{O}_{2}$ VANTs on the resultant optoelectronic and photoelectrochemical properties.[7, 66, 67]

The influence of $\mathrm{Nb}$ and $\mathrm{N}$ co-doping on the electronic structure and the band gap in particular, is also studied by conducting theoretical first principles calculations in this study to 
158 corroborate and support the experimental results. To the best of our knowledge, study of 159 photoelectrochemical activity of vertically aligned $\left(\mathrm{Sn}_{1-\mathrm{x}} \mathrm{Nb}_{\mathrm{x}}\right) \mathrm{O}_{2}: \mathrm{N}$ VANTs $(\mathrm{x}=0.05)$ as 160 photoanodes for PEC water splitting has not yet been reported to date. Thus, the present report 161 documents the theoretical and experimental studies conducted on evaluating the 162 photoelectrochemical performance of $\left(\mathrm{Sn}_{1-\mathrm{x}} \mathrm{Nb}_{\mathrm{x}}\right) \mathrm{O}_{2}: \mathrm{N}$ VANTs $(\mathrm{x}=0.05)$ as potential photoanodes 163 for PEC water splitting with the aim of achieving efficient hydrogen generation and high photon164 to-current efficiency from PEC water splitting.

165

166

\section{Results and discussion}

167 The doping strategy executed in this study, primarily utilizing $\mathrm{Nb}$ and $\mathrm{N}$, as potential dopants for $168 \mathrm{SnO}_{2}$, is expected to improve the photoelectrochemical activity of $\mathrm{SnO}_{2}$, due to a reduction in the 169 optical band gap of $\mathrm{SnO}_{2}$ and thus leading to improved light absorption. As mentioned earlier, 170 beyond an optimum concentration of the dopant, the additional electronic levels contributed by 171 the dopants can facilitate the recombination of photogenerated carriers, resulting in poor 172 photoelectrochemical activity of doped $\mathrm{SnO}_{2}$ NTs.[56, 63] In recognition of this phenomenon, $173\left(\mathrm{Sn}_{1-\mathrm{x}} \mathrm{Nb}_{\mathrm{x}}\right) \mathrm{O}_{2} \mathrm{NTs}(\mathrm{x}=0.05,0.1)$ were synthesized by hydrothermal approach and tested as a 174 photoanode primarily to select an optimal composition of $\left(\mathrm{Sn}_{1-\mathrm{x}} \mathrm{Nb}_{\mathrm{x}}\right) \mathrm{O}_{2} \mathrm{NTs}$ exhibiting superior 175 photoelectrochemical activity, in comparison to undoped $\mathrm{SnO}_{2}$ NTs. 
The XRD patterns of pure $\mathrm{SnO}_{2}$ and $\left(\mathrm{Sn}_{1-\mathrm{x}} \mathrm{Nb}_{\mathrm{x}}\right) \mathrm{O}_{2} \mathrm{NTs}(\mathrm{x}=0.05,0.1)$ are shown in Fig. 1 .

181

182

183

184

185

186

187

188

189

190

191

192

193

194

195

196

197

198

199

200

201

The XRD pattern of pure $\mathrm{SnO}_{2}$ NTs reveals presence of pure $\mathrm{SnO}_{2}$ with tetragonal structure (JCPDS 41-1445). The XRD patterns of $\left(\mathrm{Sn}_{1-\mathrm{x}} \mathrm{Nb}_{\mathrm{x}}\right) \mathrm{O}_{2}$ NTs $(\mathrm{x}=0.05,0.1)$ show peaks corresponding to $\mathrm{SnO}_{2}$ with tetragonal structure without any peaks corresponding to niobium or niobium oxide, suggesting the formation of doped $\mathrm{SnO}_{2}$ NTs. The values of molar volume and lattice parameters of $\left(\mathrm{Sn}_{1-\mathrm{x}} \mathrm{Nb}_{\mathrm{x}}\right) \mathrm{O}_{2} \mathrm{NTs}(\mathrm{x}=0.05,0.1)$, calculated using least square refinement technique are shown in Table 1. The lattice parameter and molar volume of pure $\mathrm{SnO}_{2} \mathrm{NTs}_{\mathrm{s}}$ $\mathrm{a}=\mathrm{b}=4.738 \AA, \mathrm{c}=3.187 \AA$ and $21.54 \mathrm{~cm}^{3} \mathrm{~mol}^{-1}$, respectively, which is similar to that reported earlier.[68] The decrease in lattice parameter and molar volume is observed with increase in niobium concentration. This suggests lattice contraction possibly due to the ionic radius of $\mathrm{Nb}^{4+}$ (69 pm) being smaller than $\mathrm{Sn}^{4+}(71 \mathrm{pm})$, facilitating easy replacement of $\mathrm{Sn}^{4+}$ with $\mathrm{Nb}^{4+}$ with minimum lattice distortion.[54, 55]

\section{$U V$-vis absorption study and Tauc analysis of $\left(\mathrm{Sn}_{1-x} N b_{x}\right) \mathrm{O}_{2} \mathrm{NTs}(x=0,0.05,0.1)$}

The optical properties of pure $\mathrm{SnO}_{2} \mathrm{NTs}$ and $\left(\mathrm{Sn}_{1-\mathrm{x}} \mathrm{Nb}_{\mathrm{x}}\right) \mathrm{O}_{2}$ NTs $(\mathrm{x}=0.05,0.1)$ studied using UV-visible absorption spectra are shown in Fig. 2a. The UV-vis absorption spectrum of pure $\mathrm{SnO}_{2}$ NTs shows the onset of light absorption at $\sim 350 \mathrm{~nm}$, which is similar to that reported earlier.[69, 70] The red-shift in light absorption to the visible region of interest is observed for $\left(\mathrm{Sn}_{1-\mathrm{x}} \mathrm{Nb}_{\mathrm{x}}\right) \mathrm{O}_{2} \mathrm{NTs}(\mathrm{x}=0.05,0.1)$ which increases with increase in $\mathrm{Nb}$ content. Improved light absorption with increase in $\mathrm{Nb}$ content suggests decrease in the band gap of $\left(\mathrm{Sn}_{1-\mathrm{x}} \mathrm{Nb}_{\mathrm{x}}\right) \mathrm{O}_{2} \mathrm{NTs}$, with increase in $\mathrm{Nb}$ content. The band gap of pure $\mathrm{SnO}_{2}$ and $\left(\mathrm{Sn}_{1-\mathrm{x}} \mathrm{Nb}_{\mathrm{x}}\right) \mathrm{O}_{2} \mathrm{NTs}$ is calculated from the Tauc analysis, shown in Fig. 2b, the band gap being estimated from the x-intercept of $(\alpha h v)^{2}$ 
$v s h v$ curves. The values of the band gap are shown in Table 2. The band gap of pure $\mathrm{SnO}_{2} \mathrm{NTs}$ is $3.53 \mathrm{eV}$, which is similar to that reported earlier.[71-73] The reduction in band gap is observed with increase in $\mathrm{Nb}$ content, which is primarily responsible for the improved light absorption for $\left(\mathrm{Sn}_{0.9} \mathrm{Nb}_{0.1}\right) \mathrm{O}_{2} \mathrm{NTs}$, compared to pure $\mathrm{SnO}_{2}$ and $\left(\mathrm{Sn}_{0.95} \mathrm{Nb}_{0.05}\right) \mathrm{O}_{2} \mathrm{NTs}$. The improvement in light absorption is important since it results in more number of photogenerated electrons vital for the hydrogen evolution reaction (HER).

\section{Mott-Schottky analysis of $\left(S n_{1-x} N b_{x}\right) O_{2} N T s(x=0,0.05,0.1)$}

The electronic properties of pure $\mathrm{SnO}_{2}$ NTs and doped forms, $\left(\mathrm{Sn}_{1-\mathrm{x}} \mathrm{Nb}_{\mathrm{x}}\right) \mathrm{O}_{2} \mathrm{NTs}$ are studied using Mott-Schottky analysis, performed in $0.5 \mathrm{M} \mathrm{H}_{2} \mathrm{SO}_{4}$ as the electrolyte solution at $26^{\circ} \mathrm{C}$ under dark conditions. The carrier density and flat band potential at the nanotubes/electrolyte interface are determined by the Mott-Schottky equation[34]:

$$
1 / \mathrm{C}^{2}=\left(2 / \mathrm{e}_{0} \varepsilon \varepsilon_{0} \mathrm{~N}_{\mathrm{d}}\right)\left[\left(\mathrm{V}-\mathrm{V}_{\mathrm{FB}}\right)-\mathrm{kT} / \mathrm{e}_{0}\right]
$$

where, $e_{\mathrm{o}}$ is the electron charge, $\varepsilon$ is the dielectric constant of $\mathrm{SnO}_{2}$ (taken as 13)[74, 75] $\varepsilon_{\mathrm{o}}$ is the permittivity of vacuum, $\mathrm{N}_{\mathrm{d}}$ is the dopant/carrier density, $\mathrm{V}$ is the applied electric potential, $\mathrm{V}_{\mathrm{FB}}$ is the flat band potential, $\mathrm{k}$ is the Boltzmann constant, $\mathrm{T}$ is the absolute temperature $(299 \mathrm{~K})$. The Mott-Schottky plots of $\mathrm{SnO}_{2} \mathrm{NTs}$ and $\left(\mathrm{Sn}_{1-\mathrm{x}} \mathrm{Nb}_{\mathrm{x}}\right) \mathrm{O}_{2} \mathrm{NTs}$ are shown in Fig. 2c. The flat band potential $\left(\mathrm{V}_{\mathrm{FB}}\right)$ of pure and doped $\mathrm{SnO}_{2} \mathrm{NTs}$ is found from the $\mathrm{x}$-intercept in Mott-Schottky plots $\left(1 / \mathrm{C}^{2} v s \mathrm{~V}\right)$. For undoped $\mathrm{SnO}_{2} \mathrm{NTs}, \mathrm{V}_{\mathrm{FB}}$ is $\sim 0.05 \mathrm{~V}$ ( vs RHE), while $\mathrm{V}_{\mathrm{FB}}$ for $\left(\mathrm{Sn}_{1-\mathrm{x}} \mathrm{Nb}_{\mathrm{x}}\right) \mathrm{O}_{2} \mathrm{NTs}$ $(\mathrm{x}=0.05,0.1)$ are $\sim(-0.08 \mathrm{~V})$ and $\sim(-0.1 \mathrm{~V})(v s \mathrm{RHE})$, respectively. Thus, $\mathrm{V}_{\mathrm{FB}}$ of $\left(\mathrm{Sn}_{1-\mathrm{x}} \mathrm{Nb}_{\mathrm{x}}\right) \mathrm{O}_{2}$ NTs $(\mathrm{x}=0.05,0.1)$ is more negative than the standard reduction potential of water $(0 \mathrm{~V})$, indicating that the band edge of $\left(\mathrm{Sn}_{1-\mathrm{x}} \mathrm{Nb}_{\mathrm{x}}\right) \mathrm{O}_{2} \mathrm{NTs}$ is more negative than the standard reduction potential of water. A more negative $V_{F B}$ is thus expected to offer efficient separation of the 
225 photogenerated carriers at the semiconductor-electrolyte interface due to improved band bending

226 at the semiconductor surface.[76-78] This is expected to offer a large driving force to the

227 photogenerated electrons resulting in improved photocurrent density.[76-78] The carrier density

228 is calculated from the slope determined from the Mott-Schottky plot using the following

229 equation:

$$
\mathrm{N}_{\mathrm{d}}=\left(2 / \mathrm{e}_{0} \varepsilon \varepsilon_{0}\right)\left[\mathrm{d}\left(1 / \mathrm{C}^{2}\right) / \mathrm{dV}\right]^{-1}
$$

231 The positive slope obtained in Mott-Schottky plots indicate n-type behavior for pure $\mathrm{SnO}_{2} \mathrm{NTs}$

232 and $\left(\mathrm{Sn}_{1-\mathrm{x}} \mathrm{Nb}_{\mathrm{x}}\right) \mathrm{O}_{2} \mathrm{NTs}$. The carrier density, determined from the slope of Mott-Schottky plot, for

233 pure $\mathrm{SnO}_{2}$ and $\left(\mathrm{Sn}_{1-\mathrm{x}} \mathrm{Nb}_{\mathrm{x}}\right) \mathrm{O}_{2} \mathrm{NTs}(\mathrm{x}=0.05,0.1)$, is $2.42 \times 10^{18} \mathrm{~cm}^{-3}, 4.2 \times 10^{19} \mathrm{~cm}^{-3}$ and $5.52 \times 10^{19}$

$234 \mathrm{~cm}^{-3}$, respectively (Table 2). This shows that increase in $\mathrm{Nb}$ concentration in $\mathrm{SnO}_{2} \mathrm{NTs}$ leads to 235 an almost one order increase in carrier density in comparison to undoped $\mathrm{SnO}_{2} \mathrm{NTs}$

Photoelectrochemical characterization of $\left(\mathrm{Sn}_{1-x} \mathrm{Nb} b_{x}\right) \mathrm{O}_{2} \mathrm{NTs}(x=0,0.05,0.1)$

The superior photoelectrochemical activity is expected for $\left(\mathrm{Sn}_{1-\mathrm{x}} \mathrm{Nb}_{\mathrm{x}}\right) \mathrm{O}_{2} \mathrm{NTs}(\mathrm{x}=0.1)$ due

to its lower band gap facilitating superior light absorption (as seen in UV-vis absorption spectra shown in Fig. 2a and Tauc analysis in Fig. 2b) and increased carrier density (determined from Mott-Schottky plots in Fig. 2c) than pure $\mathrm{SnO}_{2}$ and $\left(\mathrm{Sn}_{1-\mathrm{x}} \mathrm{Nb}_{\mathrm{x}}\right) \mathrm{O}_{2} \mathrm{NTs}(\mathrm{x}=0.05)$ (Table 1 and Table 2). The photoelectrochemical activity of pure $\mathrm{SnO}_{2} \mathrm{NTs}$ and $\left(\mathrm{Sn}_{1-\mathrm{x}} \mathrm{Nb}_{\mathrm{x}}\right) \mathrm{O}_{2} \mathrm{NTs}(\mathrm{x}=0.05$,

2430.1 ) is studied in $0.5 \mathrm{M} \mathrm{H}_{2} \mathrm{SO}_{4}$ as the electrolyte solution using a $300 \mathrm{~W}$ xenon lamp (Model 6258, Newport) equipped with an AM1.5G filter (Model 81094, Newport) used to simulate the

245 solar spectrum. Fig. 2d shows the uncorrected and $\mathrm{iR}_{\Omega}$ linear scan voltammogram (LSV) curves $246\left[\mathrm{R}_{\Omega}\right.$, the ohmic resistance was determined from electrochemical impedance spectroscopy (EIS) 247 analysis discussed in detail later] of $\mathrm{SnO}_{2}$ and $\left(\mathrm{Sn}_{1-\mathrm{x}} \mathrm{Nb}_{\mathrm{x}}\right) \mathrm{O}_{2} \mathrm{NTs}$, in the dark and with 
248 illumination of $100 \mathrm{~mW} \mathbf{~ m}^{-2}$ obtained with a scan rate of $1 \mathrm{mV} \mathrm{sec}^{-1}$. The LSV curve for pure $249 \mathrm{SnO}_{2} \mathrm{NTs}$ and $\left(\mathrm{Sn}_{1-\mathrm{x}} \mathrm{Nb}_{\mathrm{x}}\right) \mathrm{O}_{2} \mathrm{NTs}$ in the dark showed a small background current of $\sim 10^{-3} \mathrm{~mA}$ $250 \mathrm{~cm}^{-2}$. Pure $\mathrm{SnO}_{2}$ NTs showed poor photoelectrochemical activity with onset potential of $0.28 \mathrm{~V}$ 251 ( $v s$ RHE) and photocurrent density of $\sim 0 \mathrm{~mA} \mathbf{c m}^{-2}$ at $0.75 \mathrm{~V}$ mainly due to its wide band gap 252 (3.53 eV as shown in Table 2). In comparison to pure $\mathrm{SnO}_{2} \mathrm{NTs},\left(\mathrm{Sn}_{1-\mathrm{x}} \mathrm{Nb}_{\mathrm{x}}\right) \mathrm{O}_{2} \mathrm{NTs}(\mathrm{x}=0.05$, 253 0.1) exhibit superior photoelectrochemical activity with an onset potential of $0.17 \mathrm{~V}(v s$ RHE) 254 and showed improved photocurrent density of $0.17 \mathrm{~mA} \mathbf{c m}^{-2}$ and $0.1 \mathrm{~mA} \mathbf{c m}^{-2}$ at $0.75 \mathrm{~V}$ in $\mathrm{iR} \Omega$ 255 corrected LSV plot, respectively (Fig. 2d and Table 2). The improved photocurrent density for $256\left(\mathrm{Sn}_{1-\mathrm{x}} \mathrm{Nb}_{\mathrm{x}}\right) \mathrm{O}_{2} \mathrm{NTs}$ compared to $\mathrm{SnO}_{2} \mathrm{NTs}$ can be attributed to the lower band gap offering 257 improved light absorption (as seen in the UV-vis absorption spectra shown in Fig. 2a and Tauc 258 analysis in Fig. 2b) and increased carrier density (as found from Mott-Schottky plot in Fig. 2c). The LSV curves do not show saturation in photocurrent density possibly due to efficient separation of photogenerated carriers upon illumination at higher potential (Fig. 2d).[7, 34, 7982] It is noteworthy that $\left(\mathrm{Sn}_{0.95} \mathrm{Nb}_{0.05}\right) \mathrm{O}_{2} \mathrm{NTs}\left(0.17 \mathrm{~mA} \mathrm{~cm} \mathbf{~ c m}^{\mathbf{2}}\right)$ exhibit 1.7 times higher 262 photocurrent density than $\left(\mathrm{Sn}_{0.9} \mathrm{Nb}_{0.1}\right) \mathrm{O}_{2} \mathrm{NTs}\left(0.1 \mathrm{~mA} \mathbf{c m}^{-2}\right)$ at $0.75 \mathrm{~V}$ in the $\mathrm{iR}_{\Omega}$ corrected LSV 263 plot. This indicates that $\left(\mathrm{Sn}_{0.95} \mathrm{Nb}_{0.05}\right) \mathrm{O}_{2} \mathrm{NTs}$ exhibit improved reaction kinetics compared to 264 pure $\mathrm{SnO}_{2}$ NTs and $\left(\mathrm{Sn}_{0.9} \mathrm{Nb}_{0.1}\right) \mathrm{O}_{2} \mathrm{NTs}$, which is confirmed from electrochemical impedance 265 spectroscopy (EIS) (Fig. 2f). The low frequency EIS plots of $\mathrm{SnO}_{2}$ and $\left(\mathrm{Sn}_{1-\mathrm{x}} \mathrm{Nb}_{\mathrm{x}}\right) \mathrm{O}_{2}(\mathrm{x}=0.05$, 266 0.1), shown in Fig. 2f, show a well formed semicircle, which can be related to the water 267 oxidation reaction. The diameter of the low frequency semicircle, which is a measure of the 268 charge transfer resistance $\left(\mathrm{R}_{\mathrm{ct}}\right)$ and thus, the photoelectrochemical activity of the semiconductor 269 material of $\left(\mathrm{Sn}_{0.95} \mathrm{Nb}_{0.05}\right) \mathrm{O}_{2}$ NTs $\left(68.2 \Omega . \mathrm{cm}^{2}\right)$ is lower than $\left(\mathrm{Sn}_{0.9} \mathrm{Nb}_{0.1}\right) \mathrm{O}_{2} \mathrm{NTs}\left(84.2 \Omega . \mathrm{cm}^{2}\right)$ and 270 pure $\mathrm{SnO}_{2}$ NTs $\left(92 \Omega . \mathrm{cm}^{2}\right.$ ) (Table 3) indicating improved reaction kinetics due to relatively 
271 efficient separation and thus, minimum recombination of photogenerated carriers for

$272\left(\mathrm{Sn}_{0.95} \mathrm{Nb}_{0.05}\right) \mathrm{O}_{2}$ NTs than pure $\mathrm{SnO}_{2} \mathrm{NTs}$ and $\left(\mathrm{Sn}_{0.9} \mathrm{Nb}_{0.1}\right) \mathrm{O}_{2}$ NTs. [81, 82] As mentioned earlier,

273 it is expected that $\left(\mathrm{Sn}_{0.9} \mathrm{Nb}_{0.1}\right) \mathrm{O}_{2} \mathrm{NTs}$ will likely exhibit higher photocurrent density due to the

274 lower band gap with improved light absorption and increased carrier density than $\mathrm{SnO}_{2}$ and

$275\left(\mathrm{Sn}_{0.95} \mathrm{Nb}_{0.05}\right) \mathrm{O}_{2}$ NTs [Fig. 2 (a-c) and Table 2)]. However, higher photocurrent density for

$276\left(\mathrm{Sn}_{0.95} \mathrm{Nb}_{0.05}\right) \mathrm{O}_{2} \mathrm{NTs}$ is obtained compared to $\left(\mathrm{Sn}_{0.9} \mathrm{Nb}_{0.1}\right) \mathrm{O}_{2} \mathrm{NTs}$ and this is likely as a result of

277 the significantly lower charge-transfer resistance (i.e. more facile electron transfer kinetics) (Fig.

$278 \quad 2 f$ and Table 3).

279

Following the recently published paper by Coridan et al. [83] in accordance with IUPAC

nomenclature, the solar-to-hydrogen efficiency $(\mathrm{STH})$ of photoanode materials is defined as a 281 term to be used in the absence of bias (for zero applied potential, $\mathrm{V}=0$ ) and in the presence of 282 bias, the efficiency is considered as "applied bias photon-to-current efficiency (ABPE)", which is 283 calculated using the equation[83-85]:

\section{$\mathrm{ABPE}=\mathrm{I}(1.23-\mathrm{V}) \times \mathbf{1 0 0} / \mathrm{J}_{\text {light }} \ldots \ldots \ldots \ldots \ldots . . . .(2)$}

where, $\mathrm{I}$ is the photocurrent density at the measured potential, $\mathrm{V}$ is the applied potential and $\mathrm{J}_{\text {light }}$ 286 is the illumination intensity of $100 \mathrm{~mW} \mathrm{~cm}^{-2}$. The variation of ABPE with the applied potential is 287 shown in Fig. 2e. $\left(\mathrm{Sn}_{0.95} \mathrm{Nb}_{0.05}\right) \mathrm{O}_{2}$ NTs exhibit maximum ABPE of $0.088 \%$ at $0.82 \mathrm{~V}$. The 288 maximum ABPE obtained for $\left(\mathrm{Sn}_{0.95} \mathrm{Nb}_{0.05}\right) \mathrm{O}_{2} \mathrm{NTs}$ is higher than that for $\mathrm{SnO}_{2}(0.008 \%$ at 0.9 $289 \mathrm{~V})$ and even $\left(\mathrm{Sn}_{0.9} \mathrm{Nb}_{0.1}\right) \mathrm{O}_{2} \mathrm{NTs}(0.051 \%$ at $0.82 \mathrm{~V})$, respectively (Table 2). The lower ABPE for $290\left(\mathrm{Sn}_{0.9} \mathrm{Nb}_{0.1}\right) \mathrm{O}_{2} \mathrm{NTs}$ compared to $\left(\mathrm{Sn}_{0.95} \mathrm{Nb}_{0.05}\right) \mathrm{O}_{2} \mathrm{NTs}$ as mentioned above is thus likely due to 291 the inferior reaction kinetics compared to $\left(\mathrm{Sn}_{0.95} \mathrm{Nb}_{0.05}\right) \mathrm{O}_{2} \mathrm{NTs}$ (Fig. 2f and Table 3). 
294 far from the point of considering it in the commercialization range for PEC water splitting 295 cell.[10, 86-90] Hence, it is necessary to improve the ABPE of $\left(\mathrm{Sn}_{0.95} \mathrm{Nb}_{0.05}\right) \mathrm{O}_{2} \mathrm{NTs}$ with the aim 296 of achieving efficient and economic production of hydrogen from PEC water splitting. This is 297 achieved by co-doping $\left(\mathrm{Sn}_{0.95} \mathrm{Nb}_{0.05}\right) \mathrm{O}_{2} \mathrm{NTs}$ with nitrogen to lower the band gap further and thus 298 achieve improved light absorption, which is expected to improve the ABPE due to increase in the 299 photo-generated electrons available for HER.

\subsection{Characterization of $\left(\mathrm{Sn}_{1-x} \mathrm{Nb}_{x}\right) \mathrm{O}_{2}: \mathrm{N} N \mathrm{NT}(x=0.05)$}

The XRD patterns of $\left(\mathrm{Sn}_{0.95} \mathrm{Nb}_{0.05}\right) \mathrm{O}_{2}: \mathrm{N}-400 \quad \mathrm{NTs}, \quad\left(\mathrm{Sn}_{0.95} \mathrm{Nb}_{0.05}\right) \mathrm{O}_{2}: \mathrm{N}-500 \quad \mathrm{NTs}$, $305\left(\mathrm{Sn}_{0.95} \mathrm{Nb}_{0.05}\right) \mathrm{O}_{2}: \mathrm{N}-600$ NTs, shown in Fig. 3 (a-b), show peaks corresponding to tetragonal $\mathrm{SnO}_{2}$ without any peaks corresponding to $\mathrm{Nb}$ containing phase. The values of molar volume and lattice parameters of $\left(\mathrm{Sn}_{0.95} \mathrm{Nb}_{0.05}\right) \mathrm{O}_{2}: \mathrm{N} \mathrm{NTs}$, calculated using the least square refinement technique, are shown in Table 1. The increase in lattice parameter and molar volume is observed with increase in the temperature of heat treatment in $\mathrm{NH}_{3}$ for $\left(\mathrm{Sn}_{0.95} \mathrm{Nb}_{0.05}\right) \mathrm{O}_{2}: \mathrm{N}-400 \mathrm{NTs},\left(\mathrm{Sn}_{0.95} \mathrm{Nb}_{0.05}\right) \mathrm{O}_{2}: \mathrm{N}-$ $500 \mathrm{NTs}$ and $\left(\mathrm{Sn}_{0.95} \mathrm{Nb}_{0.05}\right) \mathrm{O}_{2}: \mathrm{N}-600 \mathrm{NTs}$, suggesting incorporation of nitrogen into the

$311\left(\mathrm{Sn}_{0.95} \mathrm{Nb}_{0.05}\right) \mathrm{O}_{2} \mathrm{NTs}$ and also lattice expansion upon nitrogen doping (due to observed negative shift in Fig. 3b).[7, 91] However, the XRD pattern of $\left(\mathrm{Sn}_{0.95} \mathrm{Nb}_{0.05}\right) \mathrm{O}_{2}: \mathrm{N}-700$ NTs shows peaks corresponding to $\mathrm{Sn}$ and $\mathrm{Nb}$, suggesting the reduction of $\left(\mathrm{Sn}_{0.95} \mathrm{Nb}_{0.05}\right) \mathrm{O}_{2} \mathrm{NTs}$ possibly by the

314 atomic hydrogen originating from the decomposition of $\mathrm{NH}_{3}[34]$. Hence, $600^{\circ} \mathrm{C}$ was used as the 315 optimal temperature for ammonolysis. 
SEM/EDAX and TEM study of $\left(S n_{1-x} N b_{x}\right) O_{2}: N-600 N T s(x=0.05)$

Scanning electron microscopy (SEM) has been carried out to study the morphology of the representative composition, $\left(\mathrm{Sn}_{0.95} \mathrm{Nb}_{0.05}\right) \mathrm{O}_{2}: \mathrm{N}-600$ NTs. SEM image showing top view and cross-sectional view of $\left(\mathrm{Sn}_{0.95} \mathrm{Nb}_{0.05}\right) \mathrm{O}_{2}: \mathrm{N}-600 \mathrm{NTs}$ is shown in Fig. 3c, respectively. Crosssectional view of $\left(\mathrm{Sn}_{0.95} \mathrm{Nb}_{0.05}\right) \mathrm{O}_{2}: \mathrm{N}-600 \mathrm{NTs}$ show dense and vertically oriented nanotubes of diameter of $180-240 \mathrm{~nm}$ and length of $\sim 14 \mu \mathrm{m}$. The SEM image of $\left(\mathrm{Sn}_{0.95} \mathrm{Nb}_{0.05}\right) \mathrm{O}_{2}: \mathrm{N}-600 \mathrm{NTs}$ reveals well-spaced nanotubes with clean surface and without any particles at the top and bottom of nanotubes. Energy dispersive x-ray spectroscopy (EDAX) is conducted to confirm the presence of elements $\mathrm{Sn}, \mathrm{Nb}$ and $\mathrm{N}$ and also, determine concentration of $\mathrm{N}$ in the $\left(\mathrm{Sn}_{0.95} \mathrm{Nb}_{0.05}\right) \mathrm{O}_{2}: \mathrm{N}$ NTs, heat-treated in $\mathrm{NH}_{3}$ at different temperatures.[7, 92, 93] EDAX spectrum of representative composition, $\left(\mathrm{Sn}_{0.95} \mathrm{Nb}_{0.05}\right) \mathrm{O}_{2}: \mathrm{N}-600 \mathrm{NTs}$, shown in Fig. 3c, confirms the presence of elements $\mathrm{Sn}, \mathrm{Nb}$ and $\mathrm{N}$. Quantitative elemental composition analysis by EDAX of $\left(\mathrm{Sn}_{0.95} \mathrm{Nb}_{0.05}\right) \mathrm{O}_{2}: \mathrm{N}-400 \mathrm{NTs},\left(\mathrm{Sn}_{0.95} \mathrm{Nb}_{0.05}\right) \mathrm{O}_{2}: \mathrm{N}-500$ NTs and $\left(\mathrm{Sn}_{0.95} \mathrm{Nb}_{0.05}\right) \mathrm{O}_{2}: \mathrm{N}-600 \mathrm{NTs}$, shown in Table 1 , shows increase in $\mathrm{N}$ concentration incorporated in $\left(\mathrm{Sn}_{0.95} \mathrm{Nb}_{0.05}\right) \mathrm{O}_{2} \mathrm{NTs}$ with increase in temperature of heat treatment in $\mathrm{NH}_{3} \cdot[7,66,67]$ TEM images of representative composition, $\left(\mathrm{Sn}_{0.95} \mathrm{Nb}_{0.05}\right) \mathrm{O}_{2}: \mathrm{N}-600 \mathrm{NTs}$, shown in Fig. 3d reveals the geometry of hollow nanotube with diameter of $\sim 180-220 \mathrm{~nm}$.

\section{$X$-ray photoelectron spectroscopy study of $\left(\mathrm{Sn}_{1-x} \mathrm{Nb}_{x}\right) \mathrm{O}_{2}: \mathrm{N} N \mathrm{NT}(x=0.05)$}

To determine the oxidation state of $\mathrm{Sn}, \mathrm{Nb}$ and $\mathrm{N}$, x-ray photoelectron spectroscopy (XPS) was carried out on $\left(\mathrm{Sn}_{0.95} \mathrm{Nb}_{0.05}\right) \mathrm{O}_{2}: \mathrm{N}$ NTs of different $\mathrm{N}$ concentration and pure $\mathrm{SnO}_{2}$ 
NTs. The XPS spectrum of Sn (Fig. 4a) of pure $\mathrm{SnO}_{2}$ shows the presence of $\mathrm{Sn} 3 \mathrm{~d}_{3 / 2}$ and $3 \mathrm{~d}_{5 / 2}$

341 doublet centered at $\sim 495.37 \mathrm{eV}$ and $\sim 486.95 \mathrm{eV}$, corresponding to $\mathrm{Sn}^{4+}$.[94] The negative shift in

342 binding energy of $\operatorname{Sn} 3 \mathrm{~d}_{3 / 2}$ and $3 \mathrm{~d}_{5 / 2}$ doublet is observed for $\left(\mathrm{Sn}_{0.95} \mathrm{Nb}_{0.05}\right) \mathrm{O}_{2}: \mathrm{N} \mathrm{NTs}$, which

343 increases with increase in $\mathrm{N}$ concentration, which is consistent with previously reported results

344 for $\mathrm{N}$-doped $\mathrm{TiO}_{2}$ nanoparticles.[95] In accordance with the previously reported results on $\mathrm{N}$ -

345 doped $\mathrm{TiO}_{2}$ nanoparticles[95], the negative shift in $\mathrm{Sn} 3 \mathrm{~d}_{3 / 2}$ and $3 \mathrm{~d}_{5 / 2}$ doublet for

$346\left(\mathrm{Sn}_{0.95} \mathrm{Nb}_{0.05}\right) \mathrm{O}_{2}: \mathrm{N}$ NTs can be assigned to change in electron density around $\mathrm{Sn}^{4+}$ due to $\mathrm{Nb}$ and

$347 \mathrm{~N}$ co-doping and thus, indicates modification in the electronic structure of $\mathrm{SnO}_{2} \mathrm{NTs}$ by $\mathrm{Nb}$ and

348 N co-doping. $[7,95]$ The XPS spectrum of N, shown in Fig. $\mathbf{4 b}$, shows the presence of N 1s peak

349 centered at $\sim 398.3 \mathrm{eV}$ for $\left(\mathrm{Sn}_{0.95} \mathrm{Nb}_{0.05}\right) \mathrm{O}_{2}: \mathrm{N}$ NTs of different $\mathrm{N}$ concentration. The $\mathrm{N} 1 \mathrm{~s}$ peak at

$350 \sim 398.3 \mathrm{eV}$ indicates the presence of oxynitride $(\mathrm{O}-\mathrm{Sn}-\mathrm{N}$ or $\mathrm{O}-\mathrm{Nb}-\mathrm{N})$ for $\left(\mathrm{Sn}_{0.95} \mathrm{Nb}_{0.05}\right) \mathrm{O}_{2}: \mathrm{N}$

351 NTs.[7, 96, 97] This shows substitutional doping of $\mathrm{N}$ at $\mathrm{O}$ sites in the lattice of

$352\left(\mathrm{Sn}_{0.95} \mathrm{Nb}_{0.05}\right) \mathrm{O}_{2}: \mathrm{N}$ NTs.[7, 34] Furthermore, the $\mathrm{N}$ composition (determined by XPS) is $\sim 14 \%$

353 for $\left(\mathrm{Sn}_{0.95} \mathrm{Nb}_{0.05}\right) \mathrm{O}_{2}: \mathrm{N}-600 \mathrm{NT}$, which is similar to that obtained from EDAX analysis. The XPS

354 spectrum of $\mathrm{Nb}$ of $\left(\mathrm{Sn}_{0.95} \mathrm{Nb}_{0.05}\right) \mathrm{O}_{2}: \mathrm{N}$ NTs, shown in Fig. 4c, shows the presence of $\mathrm{Nb} 3 \mathrm{~d}_{3 / 2}$ and

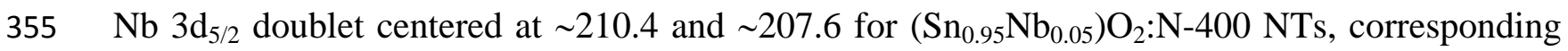

356 to $\mathrm{Nb}^{4+}$, respectively.[98, 99] The shift of $\mathrm{Nb} 3 \mathrm{~d}_{3 / 2}$ and $\mathrm{Nb} 3 \mathrm{~d}_{5 / 2}$ doublet to lower binding energy

357 value by $\sim 0.1 \mathrm{eV}$ and $\sim 0.2 \mathrm{eV}$ is observed for both $\left(\mathrm{Sn}_{0.95} \mathrm{Nb}_{0.05}\right) \mathrm{O}_{2}: \mathrm{N}-500 \mathrm{NTs}$ and

$358\left(\mathrm{Sn}_{0.95} \mathrm{Nb}_{0.05}\right) \mathrm{O}_{2}: \mathrm{N}-600 \mathrm{NTs}$, which suggests the presence of oxynitride $(\mathrm{O}-\mathrm{Nb}-\mathrm{N})$ due to

359 substitutional doping of $\mathrm{N}$ at the $\mathrm{O}$ sites.[7, 96]

$U V$-vis absorption study and Tauc analysis of $\left(\mathrm{Sn}_{1-x} \mathrm{Nb}_{x}\right) \mathrm{O}_{2}: \mathrm{N} N \mathrm{NT}(x=0.05)$

The light absorption property of $\left(\mathrm{Sn}_{0.95} \mathrm{Nb}_{0.05}\right) \mathrm{O}_{2}: \mathrm{N}$ NTs corresponding to different $\mathrm{N}$

362 concentration is studied from the UV-vis absorption spectra, shown in Fig. 5a. The UV-vis 
absorption spectra show excellent light absorption for $\left(\mathrm{Sn}_{0.95} \mathrm{Nb}_{0.05}\right) \mathrm{O}_{2}: \mathrm{N} \mathrm{NTs}$, compared to pure $\mathrm{SnO}_{2}$ and $\left(\mathrm{Sn}_{0.95} \mathrm{Nb}_{0.05}\right) \mathrm{O}_{2}$ NTs. $\left(\mathrm{Sn}_{0.95} \mathrm{Nb}_{0.05}\right) \mathrm{O}_{2}: \mathrm{N}-400 \mathrm{NTs},\left(\mathrm{Sn}_{0.95} \mathrm{Nb}_{0.05}\right) \mathrm{O}_{2}: \mathrm{N}-500$ NTs and $\left(\mathrm{Sn}_{0.95} \mathrm{Nb}_{0.05}\right) \mathrm{O}_{2}: \mathrm{N}-600 \mathrm{NTs}$ show superior light absorption than that of both pure $\mathrm{SnO}_{2}$ and $\left(\mathrm{Sn}_{0.95} \mathrm{Nb}_{0.05}\right) \mathrm{O}_{2} \mathrm{NTs}$ at $500 \mathrm{~nm}$. $500 \mathrm{~nm}$ is chosen for comparison of the absorbance of semiconductor materials in this study, as it is closest to the wavelength at which maximum solar irradiance is reportedly obtained.[100] The light absorption in the visible region increases with increase in $\mathrm{N}$ concentration for $\left(\mathrm{Sn}_{0.95} \mathrm{Nb}_{0.05}\right) \mathrm{O}_{2}: \mathrm{N}$ NTs, suggesting the reduction in the band gap due to $\mathrm{N}$ incorporation in $\left(\mathrm{Sn}_{0.95} \mathrm{Nb}_{0.05}\right) \mathrm{O}_{2} \mathrm{NTs}$. Tauc analysis as conducted earlier for the nonnitrogen doped system is accordingly conducted to determine the band gap for $\left(\mathrm{Sn}_{0.95} \mathrm{Nb}_{0.05}\right) \mathrm{O}_{2}: \mathrm{N}$ NTs. The values of the band gap determined from the Tauc analysis (Fig. 5b) are given in Table 2. As can be seen, reduction in the band gap is obtained with increase in $\mathrm{N}$ concentration for $\left(\mathrm{Sn}_{0.95} \mathrm{Nb}_{0.05}\right) \mathrm{O}_{2}: \mathrm{N}$ NTs, as indicated in Table 2. Also, the band gap of $\left(\mathrm{Sn}_{0.95} \mathrm{Nb}_{0.05}\right) \mathrm{O}_{2}: \mathrm{N}$ NTs is lower than that of pure $\mathrm{SnO}_{2} \mathrm{NTs}$ and $\left(\mathrm{Sn}_{0.95} \mathrm{Nb}_{0.05}\right) \mathrm{O}_{2} \mathrm{NTs}$. It is thus noteworthy that the lowest band gap of $1.99 \mathrm{eV}$ is achieved for $\left(\mathrm{Sn}_{0.95} \mathrm{Nb}_{0.05}\right) \mathrm{O}_{2}: \mathrm{N}-600 \mathrm{NTs}$, which is significantly lower than non-nitrogen containing $\left(\mathrm{Sn}_{0.95} \mathrm{Nb}_{0.05}\right) \mathrm{O}_{2} \mathrm{NTs}(3.1 \mathrm{eV})$ and $\mathrm{SnO}_{2} \mathrm{NTs}(3.53 \mathrm{eV})$, suggesting the beneficial role of $\mathrm{Nb}$ and $\mathrm{N}$ co-doping facilitating the reduction in the wide band gap of $\mathrm{SnO}_{2}$. This observed narrowing of the band gap for $\left(\mathrm{Sn}_{0.95} \mathrm{Nb}_{0.05}\right) \mathrm{O}_{2} \mathrm{NTs}$ after $\mathrm{N}$ incorporation is mainly attributed to the hybridization of the substitutional $\mathrm{N} 2 \mathrm{p}$ states with $\mathrm{O} 2 \mathrm{p}$ states, which is expected to shift the valence band upwards, without affecting the conduction band thereby, reducing the band gap and improving the light absorption in the visible region of interest.[7, 17] The reduction in the band gap is important since it offers improved light absorption in the visible wavelength regime of use and thus creates the appropriate conditions providing more photogenerated carriers for HER. 
The positive effect of incorporation of nitrogen in $\left(\mathrm{Sn}_{0.95} \mathrm{Nb}_{0.05}\right) \mathrm{O}_{2} \mathrm{NTs}$ on the electronic properties is, as discussed earlier for the non-nitrogen containing systems, is again studied by Mott-Schottky analysis by performing EIS in the dark in $0.5 \mathrm{M} \mathrm{H}_{2} \mathrm{SO}_{4}$ electrolyte solution at 391 $26^{\circ} \mathrm{C}$. The Mott-Schottky plot of $\left(\mathrm{Sn}_{0.95} \mathrm{Nb}_{0.05}\right) \mathrm{O}_{2}: \mathrm{N}$ NTs for different $\mathrm{N}$ concentration is shown in Fig. 5c. The flat band potential $\left(\mathrm{V}_{\mathrm{FB}}\right)$ for $\left(\mathrm{Sn}_{0.95} \mathrm{Nb}_{0.05}\right) \mathrm{O}_{2}: \mathrm{N}-400 \mathrm{NTs},\left(\mathrm{Sn}_{0.95} \mathrm{Nb}_{0.05}\right) \mathrm{O}_{2}: \mathrm{N}-500$ NTs and $\left(\mathrm{Sn}_{0.95} \mathrm{Nb}_{0.05}\right) \mathrm{O}_{2}: \mathrm{N}-600$ NTs determined from the x-intercept in Mott-Schottky plots $\left(1 / \mathrm{C}^{2} v s \mathrm{~V}\right)$ as obtained earlier for the non-nitrogen containing compositions, are $\sim(-0.2 \mathrm{~V}), \sim(-$ $0.28 \mathrm{~V})$ and $\sim(-0.33 \mathrm{~V})$ ( vs RHE), respectively. Thus, the values of $\mathrm{V}_{\mathrm{FB}}$ of $\left(\mathrm{Sn}_{0.95} \mathrm{Nb}_{0.05}\right) \mathrm{O}_{2}: \mathrm{N}$ NTs for the different $\mathrm{N}$ concentration are more negative than the standard reduction potential of water $(0 \mathrm{~V})$, indicating more negative band edge position for the $\mathrm{N}$ containing compositions $\left(\mathrm{Sn}_{0.95} \mathrm{Nb}_{0.05}\right) \mathrm{O}_{2}: \mathrm{N}$ NTs than standard reduction potential of water $(0 \mathrm{~V})$. The positive slope obtained in the Mott-Schottky plots indicate n-type behavior for $\left(\mathrm{Sn}_{0.95} \mathrm{Nb}_{0.05}\right) \mathrm{O}_{2}: \mathrm{N}$ NTs. The carrier density is determined from the slope of Mott-Schottky plot using Equation (1) as before.

401 The carrier density of $\left(\mathrm{Sn}_{0.95} \mathrm{Nb}_{0.05}\right) \mathrm{O}_{2}: \mathrm{N}-400 \quad \mathrm{NTs}, \quad\left(\mathrm{Sn}_{0.95} \mathrm{Nb}_{0.05}\right) \mathrm{O}_{2}: \mathrm{N}-500 \quad \mathrm{NTs}$ and $402\left(\mathrm{Sn}_{0.95} \mathrm{Nb}_{0.05}\right) \mathrm{O}_{2}: \mathrm{N}-600$ NTs is $3.3 \times 10^{22} \mathrm{~cm}^{-3}, 4.05 \times 10^{22} \mathrm{~cm}^{-3}$ and $4.7 \times 10^{22} \mathrm{~cm}^{-3}$, which is $3-4$ 403 orders of magnitude higher than the carrier density for the identical non-nitrogen containing 404 compositions, $\left(\mathrm{Sn}_{0.95} \mathrm{Nb}_{0.05}\right) \mathrm{O}_{2} \mathrm{NTs}\left(4.2 \times 10^{19} \mathrm{~cm}^{-3}\right)$ and $\mathrm{SnO}_{2} \mathrm{NTs}\left(2.42 \times 10^{18} \mathrm{~cm}^{-3}\right)$ (Table 2). 405 The carrier density of $\left(\sim 4.7 \times 10^{22} \mathrm{~cm}^{-3}\right)$ obtained in this study for $\left(\mathrm{Sn}_{0.95} \mathrm{Nb}_{0.05}\right) \mathrm{O}_{2}: \mathrm{N}-600 \mathrm{NTs}$ is 406 in the range of that of hydrogen-treated $\mathrm{TiO}_{2}$ nanowires $\left(\sim 2.1 \times 10^{22} \mathrm{~cm}^{-3}\right)$ [77] which showed 407 excellent photoelectrochemical activity with photoconversion efficiency of $\sim 1.63 \%$ and $\mathrm{WO}_{3}$ 408 films with superior photoelectrochemcial performance $\left(\sim 2.5 \times 10^{22} \mathrm{~cm}^{-3}\right)[101,102]$. This result 
therefore clearly demonstrates the potential of $\mathrm{N}$ doping in $\left(\mathrm{Sn}_{0.95} \mathrm{Nb}_{0.05}\right) \mathrm{O}_{2} \mathrm{NTs}$ contributing to significantly enhancing the carrier density which is vital since this implies that a higher number of photogenerated electrons are available for HER (at cathode). The increased carrier density for $\left(\mathrm{Sn}_{0.95} \mathrm{Nb}_{0.05}\right) \mathrm{O}_{2}: \mathrm{N}$ NTs with increase in $\mathrm{N}$ concentration is expected to shift the Fermi level upwards towards the conduction band resulting in negative shift in $\mathrm{V}_{\mathrm{FB}}$ (as discussed earlier) with increase in $\mathrm{N}$ concentration and thus resulting in increased degree of band bending with increase in $\mathrm{N}$ concentration.[7, 34, 76, 77, 79, 80, 103-107] This is expected to result in improved separation of photogenerated carriers at the interface between the $\left(\mathrm{Sn}_{0.95} \mathrm{Nb}_{0.05}\right) \mathrm{O}_{2}: \mathrm{N}$ NTs and the electrolyte solution, leading to improved photocurrent density and thus, superior ABPE for $\left(\mathrm{Sn}_{0.95} \mathrm{Nb}_{0.05}\right) \mathrm{O}_{2}: \mathrm{N}$ NTs, compared to pure $\mathrm{SnO}_{2}$ NTs and $\mathrm{Nb}$ doped non-nitrogen containing composition, $\left(\mathrm{Sn}_{0.95} \mathrm{Nb}_{0.05}\right) \mathrm{O}_{2} \mathrm{NTs} .[7,34,76,77,79,80,103-107]$

$\operatorname{IPCE}$ of $\left(\mathrm{Sn}_{1-x} \mathrm{Nb} b_{x}\right) \mathrm{O}_{2}: \mathrm{N} N \mathrm{NT}(x=0.05)$

To study the effect of light absorption properties on the photoelectrochemical properties, incident photon to current efficiency (IPCE) was determined for $\left(\mathrm{Sn}_{0.95} \mathrm{Nb}_{0.05}\right) \mathrm{O}_{2}$ : $\mathrm{N} \mathrm{NTs} \mathrm{using}$ different bandpass optical filters with wavelength centered at 350, 370, 400, 420, 450, 470, 500, $520,550,570$ and $600 \mathrm{~nm}$. The IPCE is calculated by the equation[108]:

$$
\operatorname{IPCE}(\%)=\frac{1240 \times \mathrm{J} \times 100}{\lambda \times \mathrm{P}}
$$

where, $\mathrm{J}$ is the measured photocurrent density $\left(\mathrm{mA} \mathbf{c m}^{-2}\right), \mathrm{P}$ is the incident light intensity ( $\mathrm{mW}$ $\left.\mathbf{c m}^{-2}\right)$ at a specific wavelength $(\lambda, \mathrm{nm})$. As shown in Fig. 6a, the IPCE value is observed to increase for $\left(\mathrm{Sn}_{0.95} \mathrm{Nb}_{0.05}\right) \mathrm{O}_{2}: \mathrm{N}$ NTs with increase in $\mathrm{N}$ concentration with the highest value obtained for $\left(\mathrm{Sn}_{0.95} \mathrm{Nb}_{0.05}\right) \mathrm{O}_{2}: \mathrm{N}-600 \mathrm{NTs}$ at all the wavelengths considered. At $500 \mathrm{~nm}$ in fact, IPCE for $\left(\mathrm{Sn}_{0.95} \mathrm{Nb}_{0.05}\right) \mathrm{O}_{2}: \mathrm{N}-400 \mathrm{NTs},\left(\mathrm{Sn}_{0.95} \mathrm{Nb}_{0.05}\right) \mathrm{O}_{2}: \mathrm{N}-500 \mathrm{NTs}$ and $\left(\mathrm{Sn}_{0.95} \mathrm{Nb}_{0.05}\right) \mathrm{O}_{2}: \mathrm{N}-600$ 
432 NTs is $2 \%, 7 \%$ and $10 \%$, respectively. This relatively large increase in IPCE with increase in N 433 concentration for $\left(\mathrm{Sn}_{0.95} \mathrm{Nb}_{0.05}\right) \mathrm{O}_{2}: \mathrm{N}$ NTs can be attributed to the lowering of the optical band 434 gap which in turn leads to improved visible light absorption and increase in carrier density, 435 thereby, resulting in enhanced charge separation, collection as well as conversion efficiency in 436 the visible region of interest. Once again, it should be mentioned that the IPCE value of $10 \%$ 437 obtained in this study for $\left(\mathrm{Sn}_{0.95} \mathrm{Nb}_{0.05}\right) \mathrm{O}_{2}: \mathrm{N}-600 \mathrm{NTs}$ at $500 \mathrm{~nm}$ is indeed the highest IPCE value 438 obtained for semiconductor materials explored so far for PEC water splitting to the best of our 439 reported understanding.[21, 34, 77, 109] The analyses conducted thus far indeed shows that $\mathrm{Nb}$ 440 and $\mathrm{N}$ co-doping together is a promising strategy for improving the photoelectrochemical activity 441 of $\mathrm{SnO}_{2}$ NT based systems.

Photoelectrochemical characterization of $\left(\mathrm{Sn}_{1-x} \mathrm{Nb}_{x}\right) \mathrm{O}_{2}: \mathrm{N} N \mathrm{NT}(x=0.05)$

The photoelectrochemical activity of $\left(\mathrm{Sn}_{0.95} \mathrm{Nb}_{0.05}\right) \mathrm{O}_{2}: \mathrm{N}$ NTs of different $\mathrm{N}$ concentration 445 is studied in $0.5 \mathrm{M} \mathrm{H}_{2} \mathrm{SO}_{4}$ as the electrolyte solution. Fig. $6 \mathbf{b}$ shows the uncorrected and $\mathrm{iR}_{\Omega}\left(\mathrm{R}_{\Omega}\right.$, 446 the ohmic resistance was determined from EIS analysis discussed in detail later) corrected linear 447 scan voltammogram (LSV) curves of $\left(\mathrm{Sn}_{0.95} \mathrm{Nb}_{0.05}\right) \mathrm{O}_{2}: \mathrm{N}$ NTs collected in the dark and with

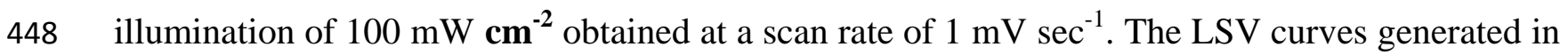
449 the dark showed a small current in the range of $\sim 10^{-3} \mathrm{~mA} \mathbf{c m}^{-2}$ for $\left(\mathrm{Sn}_{0.95} \mathrm{Nb}_{0.05}\right) \mathrm{O}_{2}: \mathrm{N}$ NTs. 450 However, an enhanced photocurrent density is observed for $\left(\mathrm{Sn}_{0.95} \mathrm{Nb}_{0.05}\right) \mathrm{O}_{2}: \mathrm{N}$ NTs under 451 illumination with onset potential of $(-0.02 \mathrm{~V}),(-0.02 \mathrm{~V})$ and $(-0.14 \mathrm{~V})(v s$ RHE) for $452\left(\mathrm{Sn}_{0.95} \mathrm{Nb}_{0.05}\right) \mathrm{O}_{2}: \mathrm{N}-400$ NTs, $\left(\mathrm{Sn}_{0.95} \mathrm{Nb}_{0.05}\right) \mathrm{O}_{2}: \mathrm{N}-500$ NTs and $\left(\mathrm{Sn}_{0.95} \mathrm{Nb}_{0.05}\right) \mathrm{O}_{2}: \mathrm{N}-600$ NTs, 453 respectively (Table 2$)$. The onset potential for $\left(\mathrm{Sn}_{0.95} \mathrm{Nb}_{0.05}\right) \mathrm{O}_{2}: \mathrm{N}$ NTs is lower than $\mathrm{SnO}_{2}(0.28$ $454 \mathrm{~V}$ vs RHE), $\left(\mathrm{Sn}_{0.95} \mathrm{Nb}_{0.05}\right) \mathrm{O}_{2}$ NTs (0.17 V vs RHE) (Table 2), indicating improvement in 
455 photoelectrochemical activity due to $\mathrm{N}$ doping in $\left(\mathrm{Sn}_{0.95} \mathrm{Nb}_{0.05}\right) \mathrm{O}_{2} \mathrm{NTs}$. Also, the decrease in the 456 onset potential with increase in $\mathrm{N}$ concentration for $\left(\mathrm{Sn}_{0.95} \mathrm{Nb}_{0.05}\right) \mathrm{O}_{2}: \mathrm{N}$ NTs suggests the 457 beneficial role of $\mathrm{N}$ in improving the photoelectrochemical activity. It is also again noteworthy to 458 point out that the negative onset potential of $\left(\mathrm{Sn}_{0.95} \mathrm{Nb}_{0.05}\right) \mathrm{O}_{2}: \mathrm{N}$ NTs of $(-0.14 \mathrm{~V}$ vs RHE) 459 obtained in this study for $\left(\mathrm{Sn}_{0.95} \mathrm{Nb}_{0.05}\right) \mathrm{O}_{2}: \mathrm{N}-600$ NTs suggests that a very minimal bias would be 460 required in converting solar energy to photocurrent density indicating superior utilization of solar 461 energy in the production of hydrogen from water, an important aspect to be considered for 462 commercialization of this novel system. The wide band gap of $\mathrm{SnO}_{2}$ usually does not allow for 463 such low onset potentials for water splitting under photo-chemical conditions. The tailoring of 464 the band gap of $\mathrm{SnO}_{2}$ by co-doping of $\mathrm{Nb}$ and $\mathrm{N}$ in this study thus results in this remarkable and 465 highly attractive photo-electrochemical behavior. The photocurrent density at $0.75 \mathrm{~V}$ [chosen 466 since the max. ABPE of $4.1 \%$ is obtained for $\left(\mathrm{Sn}_{0.95} \mathrm{Nb}_{0.05}\right) \mathrm{O}_{2}: \mathrm{N}-600 \mathrm{NTs}$ at $0.75 \mathrm{~V}$ discussed 467 later] in the $\mathrm{iR}_{\Omega}$ corrected LSV plot (Fig. 6b) for $\left(\mathrm{Sn}_{0.95} \mathrm{Nb}_{0.05}\right) \mathrm{O}_{2}: \mathrm{N}-400$ NTs, $468\left(\mathrm{Sn}_{0.95} \mathrm{Nb}_{0.05}\right) \mathrm{O}_{2}: \mathrm{N}-500 \mathrm{NTs}$ and $\left(\mathrm{Sn}_{0.95} \mathrm{Nb}_{0.05}\right) \mathrm{O}_{2}: \mathrm{N}-600 \mathrm{NTs}$ is $6.76 \mathrm{~mA} \mathbf{c m}^{\mathbf{- 2}}, 11.74 \mathrm{~mA} \mathbf{c m}^{-2}$ 469 and $25.39 \mathrm{~mA} \mathrm{~cm}^{-2}$, respectively (Table 2 ). Thus, the photocurrent density at $0.75 \mathrm{~V}$ increases 470 with progressive increase in $\mathrm{N}$ concentration for $\left(\mathrm{Sn}_{0.95} \mathrm{Nb}_{0.05}\right) \mathrm{O}_{2}: \mathrm{N}$ NTs, with the maximum 471 value obtained for $\left(\mathrm{Sn}_{0.95} \mathrm{Nb}_{0.05}\right) \mathrm{O}_{2}: \mathrm{N}-600$ NTs $\left(25.39 \mathrm{~mA} \mathrm{~cm} \mathbf{~ c m}^{-2}\right)$, which is $\sim 275 \%$ and $\sim 116 \%$ 472 higher than that obtained for $\left(\mathrm{Sn}_{0.95} \mathrm{Nb}_{0.05}\right) \mathrm{O}_{2}: \mathrm{N}-400 \mathrm{NTs}\left(6.76 \mathrm{~mA} \mathrm{~cm} \mathbf{~ c m}^{-2}\right)$ and $\left(\mathrm{Sn}_{0.95} \mathrm{Nb}_{0.05}\right) \mathrm{O}_{2}: \mathrm{N}-$ 473500 NTs $\left(11.74 \mathrm{~mA} \mathbf{c m}^{-2}\right)$, respectively. This indicates the observed improved reaction kinetics 474 and thus, photoelectrochemical activity with increase in $\mathrm{N}$ concentration for $\left(\mathrm{Sn}_{0.95} \mathrm{Nb}_{0.05}\right) \mathrm{O}_{2}: \mathrm{N}$ 475 NTs. Hence, the reaction kinetics is further studied by determining charge transfer resistance $476\left(\mathrm{R}_{\mathrm{ct}}\right)$ from EIS of $\left(\mathrm{Sn}_{0.95} \mathrm{Nb}_{0.05}\right) \mathrm{O}_{2}: \mathrm{N}$ NTs. $\mathrm{R}_{\mathrm{ct}}$ is determined from the diameter of the low 477 frequency semicircle and is shown in Table 3. As seen in Fig. 2f, $R_{c t}$ for $\left(\mathrm{Sn}_{0.95} \mathrm{Nb}_{0.05}\right) \mathrm{O}_{2}: \mathrm{N} \mathrm{NTs}$ 
478 decreases with increase in $\mathrm{N}$ concentration with the lowest $\mathrm{R}_{\mathrm{ct}}$ obtained for $\left(\mathrm{Sn}_{0.95} \mathrm{Nb}_{0.05}\right) \mathrm{O}_{2}: \mathrm{N}-$ 479600 NTs composition $\left(15.3 \Omega . \mathrm{cm}^{2}\right)$, indicating improved reaction kinetics with increase in $\mathrm{N}$ 480 concentration. Also, $\mathrm{R}_{\mathrm{ct}}$ for $\left(\mathrm{Sn}_{0.95} \mathrm{Nb}_{0.05}\right) \mathrm{O}_{2}: \mathrm{N}-600 \mathrm{NTs}\left(15.3 \Omega . \mathrm{cm}^{2}\right)$ is almost six-fold lower 481 than pure $\mathrm{SnO}_{2}\left(92 \Omega . \mathrm{cm}^{2}\right)$ and $\left(\mathrm{Sn}_{0.9} \mathrm{Nb}_{0.1}\right) \mathrm{O}_{2} \mathrm{NTs}\left(84.2 \Omega . \mathrm{cm}^{2}\right)$ and five-fold lower than $482\left(\mathrm{Sn}_{0.95} \mathrm{Nb}_{0.05}\right) \mathrm{O}_{2}$ NTs $\left(68.2 \Omega . \mathrm{cm}^{2}\right)$ (Table 3). These results concomitantly show the excellent 483 reaction kinetics and thus expectedly improved photoelectrochemical activity for $484\left(\mathrm{Sn}_{0.95} \mathrm{Nb}_{0.05}\right) \mathrm{O}_{2}: \mathrm{N}-600 \mathrm{NTs}$, in comparison to $\mathrm{SnO}_{2} \mathrm{NTs},\left(\mathrm{Sn}_{0.95} \mathrm{Nb}_{0.05}\right) \mathrm{O}_{2} \mathrm{NTs},\left(\operatorname{Sn}_{0.9} \mathrm{Nb}_{0.1}\right) \mathrm{O}_{2}$ 485 NTs, $\left(\mathrm{Sn}_{0.95} \mathrm{Nb}_{0.05}\right) \mathrm{O}_{2}: \mathrm{N}-400$ NTs and $\left(\mathrm{Sn}_{0.95} \mathrm{Nb}_{0.05}\right) \mathrm{O}_{2}: \mathrm{N}-500$ NTs. The lower $\mathrm{R}_{\mathrm{ct}}$ obtained for $486\left(\mathrm{Sn}_{0.95} \mathrm{Nb}_{0.05}\right) \mathrm{O}_{2}: \mathrm{N}-600$ NTs can be attributed to the efficient charge separation and thus, 487 minimum recombination of photogenerated carriers, as seen in the IPCE analysis (Fig. 6a) [81, 488 82]. Interestingly, there was no saturation seen in photocurrent density at higher potential under 489 illumination, possibly due to efficient separation of photogenerated carriers (Fig. 6b).[7, 34, 79490 82]

491

The photocurrent density at $0.75 \mathrm{~V}$ in $\mathrm{iR}_{\Omega}$ corrected LSV plot (Fig. 6b) for $492\left(\mathrm{Sn}_{0.95} \mathrm{Nb}_{0.05}\right) \mathrm{O}_{2}: \mathrm{N}$ NTs is significantly higher than that of pure $\mathrm{SnO}_{2} \mathrm{NTs}\left(\sim 0 \mathrm{~mA} \mathbf{c m}^{-2}\right)$ and $493\left(\mathrm{Sn}_{0.95} \mathrm{Nb}_{0.05}\right) \mathrm{O}_{2}$ NTs $\left(0.17 \mathrm{~mA} \mathbf{c m}^{-2}\right)$, suggesting remarkably improved photoelectrochemical 494 activity of $\left(\mathrm{Sn}_{0.95} \mathrm{Nb}_{0.05}\right) \mathrm{O}_{2} \mathrm{NTs}$ after $\mathrm{N}$ doping. Thus the excellent photoelectrochemical activity 495 of $\left(\mathrm{Sn}_{0.95} \mathrm{Nb}_{0.05}\right) \mathrm{O}_{2}: \mathrm{N}$ NTs which increases with increase in $\mathrm{N}$ concentration with maximum value 496 obtained for $\left(\mathrm{Sn}_{0.95} \mathrm{Nb}_{0.05}\right) \mathrm{O}_{2}: \mathrm{N}-600 \mathrm{NTs}$ can be attributed to the decrease in the band gap (as 497 seen in the Tauc analysis in Fig. 5b and Table 2) and thus, improved light absorption (as seen in 498 the UV-vis absorption spectra in Fig. 5a), increase in carrier density (as perceived in the Mott499 Schottky analysis in Fig. 5c and Table 2), improved charge separation, transport and collection 500 (as observed in the IPCE analysis in Fig. 6a) and improved electrochemical charge transfer (as 
witnessed in the EIS plots obtained under illumination in Fig. 2f and Table 3) with increase in N concentration.[7]

The variation of applied bias photon-to-current efficiency (ABPE) for $\left(\mathrm{Sn}_{0.95} \mathrm{Nb}_{0.05}\right) \mathrm{O}_{2}: \mathrm{N}$ NTs, calculated using Equation (2) with applied potential is shown in Fig. 6c. The maximum ABPE observed for $\left(\mathrm{Sn}_{0.95} \mathrm{Nb}_{0.05}\right) \mathrm{O}_{2}: \mathrm{N}-400 \quad \mathrm{NTs}, \quad\left(\mathrm{Sn}_{0.95} \mathrm{Nb}_{0.05}\right) \mathrm{O}_{2}: \mathrm{N}-500 \quad \mathrm{NTs}$ and $\left(\mathrm{Sn}_{0.95} \mathrm{Nb}_{0.05}\right) \mathrm{O}_{2}: \mathrm{N}-600 \mathrm{NTs}$ is $1.83 \%, 2.29 \%$ and $4.1 \%$ at $0.78 \mathrm{~V}, 0.78 \mathrm{~V}$ and $0.75 \mathrm{~V}$, respectively. These results indicate that the ABPE obtained for $\left(\mathrm{Sn}_{0.95} \mathrm{Nb}_{0.05}\right) \mathrm{O}_{2}: \mathrm{N}$ NTs is 100 1000 order of magnitude higher than that for $\mathrm{SnO}_{2} \mathrm{NTs}(0.008 \%$ at $0.9 \mathrm{~V})$ and $\left(\mathrm{Sn}_{0.95} \mathrm{Nb}_{0.05}\right) \mathrm{O}_{2}$ NTs $(0.088 \%$ at $0.82 \mathrm{~V})$ clearly pointing towards the beneficial role of $\mathrm{Nb}$ and $\mathrm{N}$ co-doping simultaneously leading to significant improvement in the ABPE of $\mathrm{SnO}_{2} \mathrm{NTs}$. The impressive progression seen here can be gauged from the fact that the highest ABPE obtained in this study for $\left(\mathrm{Sn}_{0.95} \mathrm{Nb}_{0.05}\right) \mathrm{O}_{2}: \mathrm{N}-600$ NTs $(4.1 \%$ at $0.75 \mathrm{~V})$ is correspondingly $\sim 124 \%$ and $\sim 79 \%$ higher than that of $\left(\mathrm{Sn}_{0.95} \mathrm{Nb}_{0.05}\right) \mathrm{O}_{2}: \mathrm{N}-400 \mathrm{NTs}(1.83 \%$ at $0.78 \mathrm{~V})$ and $\left(\mathrm{Sn}_{0.95} \mathrm{Nb}_{0.05}\right) \mathrm{O}_{2}: \mathrm{N}-500 \mathrm{NTs}$ $(2.29 \%$ at $0.78 \mathrm{~V})$, respectively. These results therefore validate the implementation of $\mathrm{N}$ as a potential dopant in improving the photoelectrochemical activity of $\left(\mathrm{Sn}_{0.95} \mathrm{Nb}_{0.05}\right) \mathrm{O}_{2} \mathrm{NTs}$.

It is also important to note that the ABPE of $4.1 \%$ obtained in this study for $\left(\mathrm{Sn}_{0.95} \mathrm{Nb}_{0.05}\right) \mathrm{O}_{2}: \mathrm{N}-600 \mathrm{NTs}$ (at $0.75 \mathrm{~V}$ ) is the highest ABPE obtained so far compared to other semiconductor materials studied as photoanode for $\mathrm{PEC}$ water splitting such as $\mathrm{TiO}_{2}, \mathrm{ZnO}$ and $\mathrm{Fe}_{2} \mathrm{O}_{3}$, to the best of our assessment of the widely reported literature to date.[7, 77, 110-112] These excellent and unprecedented results clearly show the potential of $\mathrm{Nb}$ and $\mathrm{N}$ co-doping leading to significantly improving the photoelectrochemical activity and $\mathrm{ABPE}$ of $\mathrm{SnO}_{2} \mathrm{NTs}_{\mathrm{s}}$, as evidenced in above studies. 
It is important that in addition to the excellent photoelectrochemical activity discussed

526 above, the semiconductor materials need to also exhibit adequate and acceptable long term 527 photoelectrochemical stability for use of these systems in PEC water splitting cell. Hence, 528 accordingly, chronoamperometry (CA) test has been carried out for $24 \mathrm{~h}$ to study the long term 529 photoelectrochemical stability of $\left(\mathrm{Sn}_{0.95} \mathrm{Nb}_{0.05}\right) \mathrm{O}_{2}: \mathrm{N}-600$ NTs under illumination in the 530 electrolyte solution. The CA test is carried out at a constant potential of $0.75 \mathrm{~V}$ (at which the 531 max. ABPE is obtained, as shown in Fig. 6c and Table 2) in $0.5 \mathrm{M} \mathrm{H}_{2} \mathrm{SO}_{4}$ solution by 532 illuminating the photoanode for $24 \mathrm{~h}$. The corresponding CA curve of $\left(\mathrm{Sn}_{0.95} \mathrm{Nb}_{0.05}\right) \mathrm{O}_{2}: \mathrm{N}-600$ 533 NTs is shown in Fig. 7a. A very minimal loss in photocurrent density is observed for $534\left(\mathrm{Sn}_{0.95} \mathrm{Nb}_{0.05}\right) \mathrm{O}_{2}: \mathrm{N}-600 \mathrm{NTs}$ indicating excellent photoelectrochemical stability of the co-doped 535 system. In addition, the CA curve obtained under light ON/OFF cycles shows instantaneous 536 photoresponse of $\left(\mathrm{Sn}_{0.95} \mathrm{Nb}_{0.05}\right) \mathrm{O}_{2}: \mathrm{N}-600$ NTs under illumination and also, displays superior 537 photoelectrohcemical stability with negligible loss in photocurrent density (Fig. S1 in 538 Supporting information). After $24 \mathrm{~h}$ CA test, LSV is carried out (Fig. 7b) to study and 539 determine any potential loss in photoelectrochemical activity of $\left(\mathrm{Sn}_{0.95} \mathrm{Nb}_{0.05}\right) \mathrm{O}_{2}: \mathrm{N}-600 \mathrm{NTs}$ and 540 accordingly, ensure that the system undergoes no degradation and exhibits similar 541 photoelectrochemical activity prior to the start of the CA test. Accordingly, LSV collected after $54224 \mathrm{~h}$ CA test shows negligible loss in photoelectrochemical activity of $\left(\mathrm{Sn}_{0.95} \mathrm{Nb}_{0.05}\right) \mathrm{O}_{2}: \mathrm{N}-600$ 543 NTs, suggesting the excellent photoelectrochemical stability of the co-doped system obtained 544 following ammonolysis at $600^{\circ} \mathrm{C}$. The ICP analysis conducted on the electrolyte solution 545 collected after $\mathrm{CA}$ test does not show the presence of $\mathrm{Sn}$ and $\mathrm{Nb}$ for the $\left(\mathrm{Sn}_{0.95} \mathrm{Nb}_{0.05}\right) \mathrm{O}_{2}: \mathrm{N}-600$ 546 NTs. This result is a further testimonial affirming the excellent photoelectrochemical stability of 
$547\left(\mathrm{Sn}_{0.95} \mathrm{Nb}_{0.05}\right) \mathrm{O}_{2}: \mathrm{N}-600 \mathrm{NTs}$ in the electrolyte solution under illumination of $100 \mathrm{~mW} \mathbf{c m}^{-2}$ 548 indicating the ability of the system to be deployed for long term operation in PEC water splitting 549 cell.

550

Measurement of $\mathrm{H}_{2}$ and $\mathrm{O}_{2}$ gases under illumination for $\left(\mathrm{Sn}_{1-x} \mathrm{Nb}_{x}\right) \mathrm{O}_{2}: \mathrm{N}-600 \mathrm{NTS}(x=0.05)$

552

553

554

555

556

557

558

559

560

561

562

563

564

565

566

567

568

569

Measurement of the concentration of $\mathrm{H}_{2}$ and $\mathrm{O}_{2}$ gases generated at the cathode and photoanode, respectively serves as a measure of the efficiency of the system and is thus carried out to ensure that the photocurrent is indeed arising from water splitting. Hence, during CA test of $\left(\mathrm{Sn}_{0.95} \mathrm{Nb}_{0.05}\right) \mathrm{O}_{2}: \mathrm{N}-600 \mathrm{NTs}$ at constant potential of $0.75 \mathrm{~V}$, the concentration of the gases generated were measured after $1 \mathrm{~h}$ intervals by gas chromatography. Additionally, the theoretical concentration of $\mathrm{H}_{2}$ gas is calculated from the measured photocurrent using the Faraday's law as under[108]:

$$
\text { No. of moles of } \mathrm{H}_{2}=\frac{\mathrm{Q}}{2 \mathrm{~F}}=\frac{\mathrm{It}}{2 \mathrm{~F}}=\frac{\int_{0}^{\mathrm{t}} \mathrm{I} \cdot \mathrm{d} \tau}{2 \mathrm{~F}}
$$

where, $\mathrm{I}$ is the photocurrent density, $\mathrm{t}$ is time, $\mathrm{F}$ is the Faraday constant $\left(96484.34 \mathrm{C} \mathrm{mol}^{-1}\right)$ and $\mathrm{Q}$ is the quantity of charge in coulomb. The concentration of $\mathrm{H}_{2}$ and $\mathrm{O}_{2}$ gases evolved is correspondingly shown in Fig. S2 (Supporting information). As shown in Fig. S2, the theoretical amount of evolved $\mathrm{H}_{2}$ gas is closer or comparable to the measured amount of $\mathrm{H}_{2}$, suggesting $\sim 100 \%$ Faradaic efficiency. If the decomposition of water is non-stoichiometric, there will be change in concentration of either $\mathrm{H}^{+}$or $\mathrm{OH}^{-}$ions. However, in this study, the ratio of concentration of generated $\mathrm{H}_{2}$ and $\mathrm{O}_{2}$ gases is $\sim 2$, as seen in Fig. S2 and also, there was no change observed in the $\mathrm{pH}$ of the electrolyte solution $(\sim 0)$ before and after water splitting reaction, an extremely important aspect further confirming the efficiency of the novel system. 
570 This result thus shows the expected stoichiometric decomposition of water into $\mathrm{H}_{2}$ and $\mathrm{O}_{2}$ in the

571 present study for $\left(\mathrm{Sn}_{0.95} \mathrm{Nb}_{0.05}\right) \mathrm{O}_{2}: \mathrm{N}-600 \mathrm{NTs}$ serving to demonstrate the promise of this uniquely

572 engineered system.

573

$574 \quad 2.3$ Results of the computational study

$575 \quad$ Pure $\mathrm{SnO}_{2}$

576 It should be noted that the electronic structure of pure $\mathrm{SnO}_{2}$ is ubiquitously discussed in 577 the literature[113-115] from a theoretical perspective. Nevertheless, in the context of the present 578 work it is logical to describe the electronic structure of $\mathrm{SnO}_{2}$. In addition the electronic structure 579 of pure $\mathrm{SnO}_{2}$ will be used for illustrating the combined $\mathrm{Nb}$ - and $\mathrm{N}$-doping effects on the $\mathrm{SnO}_{2}$ 580 electronic structure.

The total and projected densities of electronic states calculated for pure $\mathrm{SnO}_{2}$ are thus

582 shown in Fig. 8a. The main energy band structure of $\mathrm{SnO}_{2}$ consists of three bands, low energy 583 oxygen 2 s states ( - 18.9 to $-16.4 \mathrm{eV})$, wide valence band $(-7.9$ to $0.0 \mathrm{eV})$ consisting of 584 hybridized O-2p - Sn-5s, -5p states (forming three sub-bands with O-2p - Sn-5s, O-2p - Sn-5p, 585 and the non-hybridized O-2p states, respectively) and the conduction band consisting mainly of 586 Sn-5s states (lower band) and Sn-5p states (upper band) with relatively small admixture of the 587 oxygen $2 \mathrm{~s}$ - and $2 \mathrm{p}$ - states. The energy gap separating the top of the valence band from the 588 bottom of the conduction band of the Sn-5s character, is equal to $1.12 \mathrm{eV}$. Due to the well-known 589 intrinsic characteristic limitation of DFT (on account of self-interaction effects and derivative 590 discontinuities of the exchange correlation energy), the value of the forbidden gap is 591 underestimated substantially in comparison to the experimental measured value of $3.53 \mathrm{eV}$ (see

592 Table 4). Since the goal of the current study is to compare the general trends of the electronic 
593 structure modifications arising from the doping of $\mathrm{SnO}_{2}$ (using $\mathrm{Nb}$ and $\mathrm{N}$ ), a precise calculation

594 of the band gap is however not critical. Hence this noted disadvantage of DFT will not

595 significantly affect the results obtained and discussed in the current manuscript. Furthermore, the

596 main parameters of the electronic structure for $\mathrm{SnO}_{2}$ calculated in the present study agree well

597 with the results obtained from previously published theoretical calculations.[113-115]

598

599

$\underline{\mathrm{SnO}} \underline{2}_{2}$ doped with $\mathrm{Nb}$ and $\mathrm{N}$

600

The calculated total and projected densities of electronic states for $\left(\mathrm{Sn}_{0.94} \mathrm{Nb}_{0.06}\right) \mathrm{O}_{2}$ oxide

601

composition are shown on Fig. 8a. One can see that the main band structure of the Nb-doped

$602 \mathrm{SnO}_{2}$ is similar to the undoped $\mathrm{SnO}_{2}$. However, the main difference between the two is an

603 appearance of the $\mathrm{Nb}-4 \mathrm{~d}$ electronic states slightly hybridized with $\mathrm{Sn}-5 \mathrm{~s}$ and $\mathrm{O}-2 \mathrm{p}$ states located

604 at the bottom of the conduction band within the Fermi level vicinity. The valence band of Nb-

605 doped $\mathrm{SnO}_{2}$ remains virtually the same as that of pure $\mathrm{SnO}_{2}$ and is separated from the hybridized

606 conduction band by the energy gap of $1.08 \mathrm{eV}$. This optical band gap value is quite smaller than

607 the $\mathrm{E}_{\mathrm{BG}}$ calculated for the pure $\mathrm{SnO}_{2}(1.12 \mathrm{eV})$ which agrees well with experimental observations

608 demonstrating narrowing of the optical band gap observed with Nb-doping (Table 4). Of course,

609 both values are significantly underestimated due to the limitation of DFT analysis (mentioned

610 above). However the relative difference between these values is qualitatively the same as that

611 experimentally observed. Since the impurity $\mathrm{Nb}-4 \mathrm{~d}$ states locate at the Fermi level, it clearly

612 indicates that $\mathrm{Nb}$-doped $\mathrm{SnO}_{2}$ is a n-type semiconductor, which is in accordance with the results

613 of Mott-Schottky analysis (Fig. 2c). Also, the calculated electronic structure is very similar to

614 other calculations reported previously.[115] 
To study effect of nitrogen doping on electronic structure of $\mathrm{SnO}_{2}$ the composition $616 \mathrm{SnO}_{1.96875} \mathrm{~N}_{0.03125}$ has been considered. The projected density of electronic states for this 617 composition is shown in Fig. 8a. One can see that the general picture is almost the same as for 618 pure $\mathrm{SnO}_{2}$. The only difference between pure and $\mathrm{N}$-doped $\mathrm{SnO}_{2}$ oxide is the appearance of $\mathrm{N}-2 \mathrm{p}$ 619 impurity states at the top of the valence band. The calculated band gap $\mathrm{E}_{\mathrm{BG}}$ is $0.8 \mathrm{eV}$ (Table 4) 620 which is noticeably narrower than the corresponding calculated band gap of pure $\mathrm{SnO}_{2}$. Thus it 621 can be seen that indeed the incorporation of $\mathrm{N}$ can help decrease the optical band gap and 622 correspondingly extend the absorption of $\mathrm{SnO}_{2}$ into the visible region. Simultaneous co-doping of nitrogen together with niobium into $\mathrm{SnO}_{2}$ significantly 624 influences the electronic structure of the system within the Fermi level vicinity. Fig. 8b show the 625 calculated projected density of electronic states for $\left(\mathrm{Sn}_{0.94} \mathrm{Nb}_{0.06}\right) \mathrm{O}_{1.97} \mathrm{~N}_{0.03}$, $626\left(\mathrm{Sn}_{0.94} \mathrm{Nb}_{0.06}\right) \mathrm{O}_{1.94} \mathrm{~N}_{0.06}$, and $\left(\mathrm{Sn}_{0.94} \mathrm{Nb}_{0.06}\right) \mathrm{O}_{1.875} \mathrm{~N}_{0.125}$, respectively. One can see that the overall 627 electronic structure results from the combination of $\mathrm{Nb}$-doped $\mathrm{SnO}_{2}$ and $\mathrm{N}$-doped $\mathrm{SnO}_{2}$ 628 considered above. Compared to pure $\mathrm{SnO}_{2}$, there are $\mathrm{N}-2 \mathrm{p}$ electronic states located at the top of 629 the valence band and $\mathrm{Nb}-4 \mathrm{~d}$ electronic states located at the bottom of the conduction band, 630 separated by the energy gap $\left(\mathrm{E}_{\mathrm{BG}}\right)$. The value of this optical band gap gradually decreases with 631 increase in the concentration of $\mathrm{N}$ in the compound (from $0.93 \mathrm{eV}$ for 3 at $\%$ to $0.87 \mathrm{eV}$ for 12.5 632 at $\%$ of N). Such a narrowing of the optical band gap originates from widening of the N-2p states 633 at the top of the valence band with the corresponding increase in the N-concentration. Otherwise, 634 the overall electronic structure is virtually the same for all the three different compositions 635 containing 3, 6, and 12.5 at\% of $\mathrm{N}$ shown in Fig. 8b. Thus, the present computational study is in 636 qualitative agreement with the experimental observations reflecting a general trend of narrowing 637 the optical band gap with co-doping of $\mathrm{Nb}$ and $\mathrm{N}$ into $\mathrm{SnO}_{2}$ structure. The calculated and 
638 639 640 641 642 643 644 645 646 647 648 649 650 651 652 653 654 655 656 657 658 659 660

experimentally measured optical band gaps for all the materials considered in the present study are shown in Table 4.

The present experimental and theoretical study clearly demonstrates the excellent photoelectrochemical performance and stability of $\left(\mathrm{Sn}_{0.95} \mathrm{Nb}_{0.05}\right) \mathrm{O}_{2}: \mathrm{N}-600$ NTs with an unprecedented $\mathrm{ABPE}$ of $4.1 \%$ representing in fact, the highest $\mathrm{ABPE}$ obtained so far to the best of our analysis and assessment of the reported data to date compared to other well studied semiconductor materials used widely as photoanodes for PEC water splitting, such as $\mathrm{TiO}_{2}, \mathrm{ZnO}$ and $\mathrm{Fe}_{2} \mathrm{O}_{3} \cdot[7,77,110-112]$ This superior photoelectrochemical performance of $\left(\mathrm{Sn}_{0.95} \mathrm{Nb}_{0.05}\right) \mathrm{O}_{2}: \mathrm{N}-600 \mathrm{NTs}$ can be attributed to significant reduction in the band gap, as also validated by theoretical first principles calculations (Fig. 8a-b) and confirmed from the UV-vis absorption spectra and Tauc analysis (Fig. 5a-b ), resulting in reduction in band gap of pure $\mathrm{SnO}_{2} \mathrm{NTs}$ from $3.53 \mathrm{eV}$ to $1.99 \mathrm{eV}$ for $\left(\mathrm{Sn}_{0.95} \mathrm{Nb}_{0.05}\right) \mathrm{O}_{2}: \mathrm{N}-600 \mathrm{NTs}$. The lowered optical band gap further facilitates excellent light absorption (Fig. 5a-b). In addition to improved light absorption property, excellent photoelectrochemical performance of $\left(\mathrm{Sn}_{0.95} \mathrm{Nb}_{0.05}\right) \mathrm{O}_{2}: \mathrm{N}-600 \mathrm{NTs}$ compared to other materials in this study is observed which can be attributed to the significantly improved carrier density (Fig. 5c and Table 2), improved carrier separation and collection efficiency (Fig. 6a) and improved electrochemical charge transfer kinetics (Fig. 2f). Furthermore, $\left(\mathrm{Sn}_{0.95} \mathrm{Nb}_{0.05}\right) \mathrm{O}_{2}: \mathrm{N}-600$ NTs exhibit excellent long term photoelectrochemical stability as witnessed by the CA test carried out under illumination for $24 \mathrm{~h}$ (Fig. 7a-b). A detailed study of effect of structural and synthesis parameters of nanotubes on fundamental photoelectrochemical properties of $\mathrm{SnO}_{2}$ before and after doping will be reported in the future. All of the above results thus clearly show that $\left(\mathrm{Sn}_{0.95} \mathrm{Nb}_{0.05}\right) \mathrm{O}_{2}: \mathrm{N}-600 \mathrm{NTs}$ is indeed a promising semiconductor material with excellent photoelectrochemical performance and stability and an 
661 outstanding $\mathrm{ABPE}$ of $4.1 \%$ truly demonstrating the outstanding promise of this engineered

662 system. The results discussed herein are thus indeed important and provide a framework for

663 gradually transforming the system further towards achieving efficient hydrogen production by

664 utilizing solar energy in an environmental friendly manner thus solving global energy demand.

665

666 Conclusion

667 The photoelectrochemical activity of a carefully engineered and band gap tailored system

$668\left(\mathrm{Sn}_{0.95} \mathrm{Nb}_{0.05}\right) \mathrm{O}_{2}: \mathrm{N}$ NTs is reported in this study. The nanotubes were synthesized using $\mathrm{ZnO}$

669 NWs as sacrificial template followed by systematic heat treatment in $\mathrm{NH}_{3}$ atmosphere. This work

670 clearly demonstrates the potential of $\mathrm{Nb}$ and $\mathrm{N}$ co-doping to significantly reduce the optical band

671 gap of $\mathrm{SnO}_{2} \mathrm{NTs}$ from $3.53 \mathrm{eV}$ to $1.99 \mathrm{eV}$ for $\left(\mathrm{Sn}_{0.95} \mathrm{Nb}_{0.05}\right) \mathrm{O}_{2}: \mathrm{N}-600 \mathrm{NTs}$ leading to excellent

672 light absorption characteristics. Accordingly, $\mathrm{Nb}$ and $\mathrm{N}$ co-doping results in 4-orders of

673 magnitude improved carrier density, improved carrier separation and transport and collection

674 efficiency as well as outstanding ABPE, along with negative onset potential (-0.02 V to $-0.14 \mathrm{~V})$

675 indicating superior photoelectrochemical activity. The optical band gap of $\left(\mathrm{Sn}_{0.95} \mathrm{Nb}_{0.05}\right) \mathrm{O}_{2}: \mathrm{N}-$

676600 NTs is indeed the lowest reported for $\mathrm{SnO}_{2}$ based materials combined with significantly

677 improved carrier density which together opens up new ground for this material to be explored for

678 different solar energy based applications. The ABPE of $4.1 \%$ obtained for $\left(\mathrm{Sn}_{0.95} \mathrm{Nb}_{0.05}\right) \mathrm{O}_{2}: \mathrm{N}-$

$679600 \mathrm{NTs}$ at $0.75 \mathrm{~V}(v s \mathrm{RHE})$ is indeed the highest ABPE reported so far following careful

680 assessment of the reports available in the literature to date compared to other well-known

681 materials, $\mathrm{ZnO}, \mathrm{Fe}_{2} \mathrm{O}_{3}$ and $\mathrm{TiO}_{2}$. Furthermore, $\left(\mathrm{Sn}_{0.95} \mathrm{Nb}_{0.05}\right) \mathrm{O}_{2}: \mathrm{N}-600$ NTs exhibit excellent

682 long term photoelectrochemical stability in the electrolyte solution under illumination.

683 Theoretical first principles calculations also revealed strong effects of $\mathrm{Nb}$ - and $\mathrm{N}$-doping on 
684 electronic structure of $\mathrm{SnO}_{2}$ in general, and on the optical band gap width in particular. The 685 computational study also sheds light to clearly demonstrate the favorable benefits of 686 simultaneous doping of $\mathrm{Nb}$ and $\mathrm{N}$ to decrease substantially the optical band gap serving to move

687 the absorption of $\mathrm{SnO}_{2}$ into the visible region. Moreover, the theoretical results complement and 688 agree well with the experimental observations conducted in the present study. The $\mathrm{Nb}$ and $\mathrm{N}$ co689 doping strategy for $\mathrm{SnO}_{2}$ thus results in excellent photoelectrochemical performance for $690\left(\mathrm{Sn}_{0.95} \mathrm{Nb}_{0.05}\right) \mathrm{O}_{2}: \mathrm{N}-600$ NTs mainly due to (a) excellent light absorption properties, (b) increased 691 carrier density, and (c) facile electrochemical charge transfer. This work will therefore be 692 important in the pursuit of photoelectrochemically active and stable semiconductor materials for 693 efficient and economical hydrogen generation from PEC water splitting.

694

695 Author contribution

696 P.P.P. and P.N.K. devised the original concept. P.P.P. designed the experiments, 697 synthesized the materials, prepared the electrodes, performed structural and 698 photoelectrochemical characterization and analyzed structural and photoelectrochemical data. 699 O.I.V. conducted the theoretical analyses. J.P. and A.M. collected and analyzed the XPS data. 700 P.P.P. performed SEM/EDAX. B.G. carried out TEM. M.K.D. and P.J made important 701 suggestions in the context of fundamental structural and photoelectochemical characterization. P. 702 P. P., P. J., O.I.V. and P.N.K. wrote the first draft of the paper; and all authors participated in the 703 manuscript revision. The project is conceived and supervised by P.N.K.

704

705 Acknowledgment: 
Research in part supported by the National Science Foundation, CBET - Grant 0933141.

707 P.N.K acknowledges the Edward R. Weidlein Chair Professorship funds and the Center for

708 Complex Engineered Multifunctional Materials (CCEMM), Swanson School of Engineering,

709 University of Pittsburgh for support of this research and also for procurement of the

710 electrochemical equipment and facilities used in this research work. P.N.K also acknowledges

711 Mr. Matt Detzel (Chemical Engineering Undergraduate Laboratory Technician/Instructor,

712 University of Pittsburgh) for allowing to use UV-vis spectrophotometer and gas chromatography

713 (GC) system. Finally, P.N.K and O.I.V gratefully acknowledge the support of the Pittsburgh

714 Supercomputing Center for allocating the computational units needed to complete the theoretical 715 component of the present study.

716

717 References

718 [1] B.K. Bose, Industrial Electronics, IEEE Transactions on, 60 (2013) 2638-2651.

719 [2] G.P. Peters, R.M. Andrew, T. Boden, J.G. Canadell, P. Ciais, C. Le Quere, G. Marland, M.R.

720 Raupach, C. Wilson, Nature Clim. Change, 3 (2013) 4-6.

721 [3] T. Stocker, D. Qin, G. Plattner, M. Tignor, S. Allen, J. Boschung, A. Nauels, Y. Xia, V. Bex,

722 P. Midgley, IPCC Localised, 9 (2013) 2013.

723 [4] J.R. Miller, Science, 335 (2012) 1312-1313.

724 [5] M.G. Walter, E.L. Warren, J.R. McKone, S.W. Boettcher, Q. Mi, E.A. Santori, N.S. Lewis, 725 Chemical reviews, 110 (2010) 6446-6473.

726 [6] P.P. Patel, P.H. Jampani, M.K. Datta, O.I. Velikokhatnyi, D. Hong, J.A. Poston, A. 727 Manivannan, P.N. Kumta, Journal of Materials Chemistry A, 3 (2015) 18296-18309. 
728 [7] P.P. Patel, P.J. Hanumantha, O.I. Velikokhatnyi, M.K. Datta, D. Hong, B. Gattu, J.A. Poston, 729 A. Manivannan, P.N. Kumta, Journal of Power Sources, 299 (2015) 11-24.

730 [8] P.P. Patel, M.K. Datta, O.I. Velikokhatnyi, P. Jampani, D. Hong, J.A. Poston, A. 731 Manivannan, P.N. Kumta, Journal of Materials Chemistry A, 3 (2015) 14015-14032.

732 [9] P.P. Patel, M.K. Datta, P.H. Jampani, D. Hong, J.A. Poston, A. Manivannan, P.N. Kumta, 733 Journal of Power Sources, 293 (2015) 437-446.

734 [10] A.J. Bard, M.A. Fox, Accounts of Chemical Research, 28 (1995) 141-145.

735 [11] M. Balat, M. Balat, International journal of hydrogen energy, 34 (2009) 3589-3603.

736 [12] T. Bak, J. Nowotny, M. Rekas, C. Sorrell, International journal of hydrogen energy, 27 737 (2002) 991-1022.

738 [13] X. Chen, S. Shen, L. Guo, S.S. Mao, Chemical Reviews, 110 (2010) 6503-6570.

739 [14] G.W. Crabtree, M.S. Dresselhaus, M.V. Buchanan, Physics Today, 57 (2004) 39-44.

740 [15] Z. Zou, J. Ye, K. Sayama, H. Arakawa, Nature, 414 (2001) 625-627.

741 [16] J.A. Turner, Science, 285 (1999) 687-689.

742 [17] K. Maeda, Physical Chemistry Chemical Physics, 15 (2013) 10537-10548.

743 [18] M. Sener, J.E. Stone, A. Barragan, A. Singharoy, I. Teo, K.L. Vandivort, B. Isralewitz, B. 744 Liu, B.C. Goh, J.C. Phillips, Proceedings of the International Conference on High Performance 745 Computing, Networking, Storage and Analysis, SC '14, IEEE Press (2014).

746 [19] X. Peng, C. He, X. Fan, Q. Liu, J. Zhang, H. Wang, International Journal of Hydrogen 747 Energy, 39 (2014) 14166-14171.

748 [20] A. Fujishima, nature, 238 (1972) 37-38.

749 [21] A. Kushwaha, M. Aslam, Electrochimica Acta, 130 (2014) 222-231.

750 [22] X. Zhang, Y. Liu, Z. Kang, ACS applied materials \& interfaces, 6 (2014) 4480-4489. 
751 [23] C.X. Kronawitter, L. Vayssieres, S. Shen, L. Guo, D.A. Wheeler, J.Z. Zhang, B.R. Antoun, 752 S.S. Mao, Energy \& Environmental Science, 4 (2011) 3889-3899.

753 [24] H.M. Chen, C.K. Chen, R.-S. Liu, L. Zhang, J. Zhang, D.P. Wilkinson, Chemical Society $754 \quad$ Reviews, 41 (2012) 5654-5671.

755 [25] F.E. Osterloh, Chemical Society Reviews, 42 (2013) 2294-2320.

756 [26] M.M. Momeni, Y. Ghayeb, M. Davarzadeh, Journal of Electroanalytical Chemistry, 739 757 (2015) 149-155.

758 [27] M.M. Momeni, Y. Ghayeb, Z. Ghonchegi, J Solid State Electrochem, 19 (2015) 1359-1366.

759 [28] M.M. Momeni, Y. Ghayeb, Z. Ghonchegi, Ceramics International, 41 (2015) 8735-8741.

760 [29] M.M. Momeni, Y. Ghayeb, Journal of Alloys and Compounds, 637 (2015) 393-400.

761 [30] M.M. Momeni, Y. Ghayeb, J Appl Electrochem, 45 (2015) 557-566.

762 [31] M.M. Momeni, Y. Ghayeb, Journal of Electroanalytical Chemistry, 751 (2015) 43-48.

763 [32] M.M. Momeni, Y. Ghayeb, F. Mohammadi, Journal of Materials Science: Materials in 764 Electronics, 26 (2015) 685-692.

765 [33] M. Ni, M.K. Leung, D.Y. Leung, K. Sumathy, Renewable and Sustainable Energy Reviews, $76611(2007) 401-425$.

767 [34] X. Yang, A. Wolcott, G. Wang, A. Sobo, R.C. Fitzmorris, F. Qian, J.Z. Zhang, Y. Li, Nano $768 \quad$ Letters, 9 (2009) 2331-2336.

769 [35] A. Tacca, L. Meda, G. Marra, A. Savoini, S. Caramori, V. Cristino, C.A. Bignozzi, V.G. 770 Pedro, P.P. Boix, S. Gimenez, J. Bisquert, ChemPhysChem, 13 (2012) 3025-3034.

771 [36] M. Kitano, M. Matsuoka, M. Ueshima, M. Anpo, Applied Catalysis A: General, 325 (2007) $772 \quad 1-14$.

773 [37] K. Sivula, F. Le Formal, M. Grätzel, ChemSusChem, 4 (2011) 432-449. 
774 [38] F.E. Osterloh, B.A. Parkinson, MRS bulletin, 36 (2011) 17-22.

775 [39] M.A. Mayer, K.M. Yu, D.T. Speaks, J.D. Denlinger, L.A. Reichertz, J.W. Beeman, E.E.

776 Haller, W. Walukiewicz, Journal of Physical Chemistry C, 116 (2012) 15281-15289.

777 [40] M.K. Datta, K. Kadakia, O.I. Velikokhatnyi, P.H. Jampani, S.J. Chung, J.A. Poston, A. 778 Manivannan, P.N. Kumta, Journal of Materials Chemistry A, 1 (2013) 4026-4037.

779 [41] K. Kadakia, M.K. Datta, O.I. Velikokhatnyi, P.H. Jampani, P.N. Kumta, International 780 Journal of Hydrogen Energy, 39 (2014) 664-674.

781 [42] M. Pourbaix, Atlas of electrochemical equilibria in aqueous solutions, Pergamon Press, 782 Oxford, 1974.

783 [43] Y. Tamaki, K. Hara, R. Katoh, M. Tachiya, A. Furube, The Journal of Physical Chemistry $784 \quad$ C, $113(2009)$ 11741-11746.

785 [44] E. Ramasamy, J. Lee, The Journal of Physical Chemistry C, 114 (2010) 22032-22037.

786 [45] Y. Wang, Q. Wang, X. Zhan, F. Wang, M. Safdar, J. He, Nanoscale, 5 (2013) 8326-8339.

787 [46] C. Cheng, Y.Y. Tay, H.H. Hng, H.J. Fan, Journal of Materials Research, 26 (2011) 22547882260.

789 [47] C. Cheng, W. Ren, H. Zhang, Nano Energy, 5 (2014) 132-138.

790 [48] C. Gao, Z. Zhang, X. Li, L. Chen, Y. Wang, Y. He, F. Teng, J. Zhou, W. Han, E. Xie, Solar 791 Energy Materials and Solar Cells, 141 (2015) 101-107.

792 [49] Z. Zhang, C. Gao, Z. Wu, W. Han, Y. Wang, W. Fu, X. Li, E. Xie, Nano Energy, 19 (2016) $793 \quad 318-327$.

794 [50] Y. Wang, T. Brezesinski, M. Antonietti, B. Smarsly, ACS nano, 3 (2009) 1373-1378.

795 [51] V. Gokulakrishnan, S. Parthiban, K. Jeganathan, K. Ramamurthi, J Mater Sci, 46 (2011) $796 \quad 5553-5558$. 
797 [52] M. Stefik, M. Cornuz, N. Mathews, T. Hisatomi, S. Mhaisalkar, M. Grätzel, Nano letters, 12 798 (2012) 5431-5435.

799 [53] G. Turgut, E. Keskenler, S. Aydın, M. Yılmaz, S. Doğan, B. Düzgün, Physica Scripta, 87 $800 \quad$ (2013) 035602.

801 [54] S.-i. Shamoto, T. Nakano, Y. Nozue, T. Kajitani, Journal of Physics and Chemistry of 802 Solids, 63 (2002) 1047-1050.

803 [55] R. Katiyar, P. Dawson, M. Hargreave, G. Wilkinson, Journal of Physics C: Solid State 804 Physics, 4 (1971) 2421-2431.

805 [56] R. Asahi, T. Morikawa, T. Ohwaki, K. Aoki, Y. Taga, Science, 293 (2001) 269-271.

806 [57] C. Burda, Y. Lou, X. Chen, A.C.S. Samia, J. Stout, J.L. Gole, Nano Letters, 3 (2003) 10498071051.

808 [58] R. Beranek, B. Neumann, S. Sakthivel, M. Janczarek, T. Dittrich, H. Tributsch, H. Kisch, 809 Chemical Physics, 339 (2007) 11-19.

810 [59] S. Hoang, S. Guo, N.T. Hahn, A.J. Bard, C.B. Mullins, Nano Letters, 12 (2011) 26-32.

811 [60] M. Law, L.E. Greene, J.C. Johnson, R. Saykally, P. Yang, Nature materials, 4 (2005) 455812459.

813 [61] A. Kushwaha, M. Aslam, Journal of Applied Physics, 112 (2012) 054316.

814 [62] L. Mai, X. Tian, X. Xu, L. Chang, L. Xu, Chemical reviews, 114 (2014) 11828-11862.

815 [63] Q. Xiao, J. Zhang, C. Xiao, X. Tan, Materials Science and Engineering: B, 142 (2007) 121816125.

817 [64] S. Deki, S. Iizuka, A. Horie, M. Mizuhata, A. Kajinami, Chemistry of Materials, 16 (2004) $818 \quad 1747-1750$. 
819 [65] J.-H. Lee, I.-C. Leu, M.-C. Hsu, Y.-W. Chung, M.-H. Hon, The Journal of Physical 820 Chemistry B, 109 (2005) 13056-13059.

821 [66] J. Wang, D.N. Tafen, J.P. Lewis, Z. Hong, A. Manivannan, M. Zhi, M. Li, N. Wu, Journal 822 of the American Chemical Society, 131 (2009) 12290-12297.

823 [67] J. Huang, Z. Ye, H. Chen, B. Zhao, L. Wang, Journal of materials science letters, 22 (2003) $824 \quad 249-251$.

825 [68] M.S. Park, G.X. Wang, Y.M. Kang, D. Wexler, S.X. Dou, H.K. Liu, Angewandte Chemie, $826119(2007) 764-767$.

827 [69] I. Bedja, P.V. Kamat, The Journal of Physical Chemistry, 99 (1995) 9182-9188.

828 [70] S. Luo, J. Fan, W. Liu, M. Zhang, Z. Song, C. Lin, X. Wu, P.K. Chu, Nanotechnology, 17 829 (2006) 1695-1699.

830 [71] B. Canava, D. Lincot, J Appl Electrochem, 30 (2000) 711-716.

831 [72] C.-M. Fan, Y. Peng, Q. Zhu, L. Lin, R.-X. Wang, A.-W. Xu, The Journal of Physical 832 Chemistry C, 117 (2013) 24157-24166.

833 [73] T. Nishino, Y. Hamakawa, Japanese Journal of Applied Physics, 9 (1970) 1085-1090.

834 [74] D.M. Roessler, W.A. Albers Jr, Journal of Physics and Chemistry of Solids, 33 (1972) 293835296.

836 [75] J.M.D. Coey, A.P. Douvalis, C.B. Fitzgerald, M. Venkatesan, Appl. Phys. Lett., 84 (2004) $837 \quad 1332-1334$.

838 [76] J.M. Bolts, M.S. Wrighton, The Journal of Physical Chemistry, 80 (1976) 2641-2645.

839 [77] G. Wang, H. Wang, Y. Ling, Y. Tang, X. Yang, R.C. Fitzmorris, C. Wang, J.Z. Zhang, Y. 840 Li, Nano letters, 11 (2011) 3026-3033. 
841 [78] S. Hernández, V. Cauda, A. Chiodoni, S. Dallorto, A. Sacco, D. Hidalgo, E. Celasco, C.F. 842 Pirri, ACS Applied Materials \& Interfaces, 6 (2014) 12153-12167.

843 [79] Y. Qiu, K. Yan, H. Deng, S. Yang, Nano letters, 12 (2011) 407-413.

844 [80] Q. Liu, H. Lu, Z. Shi, F. Wu, J. Guo, K. Deng, L. Li, ACS Applied Materials \& Interfaces, 6 845 (2014) 17200-17207.

846 [81] F. Su, T. Wang, R. Lv, J. Zhang, P. Zhang, J. Lu, J. Gong, Nanoscale, 5 (2013) 9001-9009.

847 [82] Y. Yang, X.-j. Li, J.-t. Chen, L.-y. Wang, Journal of Photochemistry and Photobiology A: 848 Chemistry, 163 (2004) 517-522.

849 [83] R.H. Coridan, A.C. Nielander, S.A. Francis, M.T. McDowell, V. Dix, S.M. Chatman, N.S. 850 Lewis, Energy \& Environmental Science, 8 (2015) 2886-2901.

851 [84] J. Luo, J. Chen, H. Wang, H. Liu, Journal of Power Sources, 303 (2016) 287-293.

852 [85] Y. Mi, L. Wen, R. Xu, Z. Wang, D. Cao, Y. Fang, Y. Lei, Advanced Energy Materials, 6 $853 \quad$ (2016) 1501496.

854 [86] B.D. James, G.N. Baum, J. Perez, K.N. Baum, O.V. Square, Directed Technologies Inc., 855 Department of Energy contract GS-10F-009J technical report, (2009).

856 [87] J. Liu, T. Hisatomi, G. Ma, A. Iwanaga, T. Minegishi, Y. Moriya, M. Katayama, J. Kubota, 857 K. Domen, Energy \& Environmental Science, 7 (2014) 2239-2242.

858 [88] R. van de Krol, M. Grätzel, Photoelectrochemical hydrogen production, Springer, 2011.

859 [89] M.F. Weber, M.J. Dignam, Journal of The Electrochemical Society, 131 (1984) 1258-1265.

860 [90] J. Li, N. Wu, Catalysis Science \& Technology, 5 (2015) 1360-1384.

861 [91] B. Yao, L.X. Guan, G.Z. Xing, Z.Z. Zhang, B.H. Li, Z.P. Wei, X.H. Wang, C.X. Cong, Y.P. 862 Xie, Y.M. Lu, D.Z. Shen, Journal of Luminescence, 122-123 (2007) 191-194.

863 [92] H. Wu, Z. Zhang, International Journal of Hydrogen Energy, 36 (2011) 13481-13487. 
864 [93] J. Xu, Y. Ao, M. Chen, D. Fu, Applied Surface Science, 256 (2010) 4397-4401.

865 [94] W.K. Choi, H.J. Jung, S.K. Koh, Journal of Vacuum Science \& Technology A, 14 (1996)

$866 \quad 359-366$.

867 [95] M. Sathish, B. Viswanathan, R.P. Viswanath, C.S. Gopinath, Chemistry of Materials, 17 868 (2005) 6349-6353.

869 [96] R. Ohnishi, M. Katayama, K. Takanabe, J. Kubota, K. Domen, Electrochimica Acta, 55 870 (2010) 5393-5400.

871 [97] M. Himmerlich, M. Koufaki, G. Ecke, C. Mauder, V. Cimalla, J.A. Schaefer, A. Kondilis, 872 N.T. Pelekanos, M. Modreanu, S. Krischok, ACS applied materials \& interfaces, 1 (2009) 14518731456.

874 [98] D.D. Sarma, C.N.R. Rao, Journal of Electron Spectroscopy and Related Phenomena, 20 875 (1980) 25-45.

876 [99] J. Jouve, Y. Belkacem, C. Severac, Thin Solid Films, 139 (1986) 67-75.

877 [100] M. Chen, R.E. Blankenship, Trends in Plant Science, 16 (2011) 427-431.

878 [101] W. Li, J. Li, X. Wang, J. Ma, Q. Chen, International Journal of Hydrogen Energy, 35 879 (2010) 13137-13145.

880 [102] M. Yagi, S. Maruyama, K. Sone, K. Nagai, T. Norimatsu, Journal of Solid State 881 Chemistry, 181 (2008) 175-182.

882 [103] S. Xie, X. Lu, T. Zhai, W. Li, M. Yu, C. Liang, Y. Tong, Journal of Materials Chemistry, $88322(2012) 14272-14275$.

884 [104] Y.-Z. Zheng, H. Ding, X. Tao, J.-F. Chen, Materials Research Bulletin, 55 (2014) 182-189.

885 [105] G. Wang, Y. Ling, Y. Li, Nanoscale, 4 (2012) 6682-6691. 
886 [106] C. Yang, Z. Wang, T. Lin, H. Yin, X. Lü, D. Wan, T. Xu, C. Zheng, J. Lin, F. Huang, 887 Journal of the American Chemical Society, 135 (2013) 17831-17838.

888 [107] H. Cui, W. Zhao, C. Yang, H. Yin, T. Lin, Y. Shan, Y. Xie, H. Gu, F. Huang, J. Mater. 889 Chem. A, 2 (2014) 8612-8616.

890 [108] B. AlOtaibi, H.P.T. Nguyen, S. Zhao, M.G. Kibria, S. Fan, Z. Mi, Nano Letters, 13 (2013) $891 \quad 4356-4361$.

892 [109] Z. Zhang, L. Zhang, M.N. Hedhili, H. Zhang, P. Wang, Nano Letters, 13 (2012) 14-20.

893 [110] I.S. Cho, Z. Chen, A.J. Forman, D.R. Kim, P.M. Rao, T.F. Jaramillo, X. Zheng, Nano 894 Letters, 11 (2011) 4978-4984.

895 [111] H. Dotan, K. Sivula, M. Gratzel, A. Rothschild, S.C. Warren, Energy \& Environmental 896 Science, 4 (2011) 958-964.

897 [112] Q. Liu, D. Ding, C. Ning, X. Wang, International Journal of Hydrogen Energy, 40 (2015) $898 \quad 2107-2114$.

899 [113] Y. Duan, Physical Review B, 77 (2008) 045332.

900 [114] M.A. Mäki-Jaskari, T.T. Rantala, Physical Review B, 64 (2001) 075407.

901 [115] J. Xu, S. Huang, Z. Wang, Solid State Communications, 149 (2009) 527-531.

902

903

904

905

906

907

908 
Table 1. The lattice parameter and molar volume for $\mathrm{SnO}_{2},\left(\mathrm{Sn}_{1-\mathrm{x}} \mathrm{Nb}_{\mathrm{x}}\right) \mathrm{O}_{2}(\mathrm{x}=\mathbf{0 , 0 . 0 5 , 0 . 1 )}$

911 (obtained from EDAX analysis)

\begin{tabular}{|c|c|c|c|}
\hline Composition & $\begin{array}{c}\text { Lattice } \\
\text { parameter } \\
\text { (nm) }\end{array}$ & $\begin{array}{c}\text { Molar } \\
\text { volume } \\
\left(\mathrm{cm}^{3} \mathrm{~mol}^{-1}\right)\end{array}$ & $\begin{array}{c}\text { N concentration } \\
\text { from } E D A X \\
\text { analysis } \\
(\text { at. } \%)\end{array}$ \\
\hline $\mathrm{SnO}_{2}$ & $\begin{array}{c}a=b=0.4738 \\
c=0.3187\end{array}$ & 21.54 & - \\
\hline$\left(\mathrm{Sn}_{0.95} \mathrm{Nb}_{0.05}\right) \mathrm{O}_{2}$ & $\begin{array}{c}\mathrm{a}=\mathrm{b}=0.4735 \\
\mathrm{c}=0.3184\end{array}$ & 21.49 & - \\
\hline$\left(\mathrm{Sn}_{0.9} \mathrm{Nb}_{0.1}\right) \mathrm{O}_{2}$ & $\begin{array}{c}\mathrm{a}=\mathrm{b}=0.4732 \\
\mathrm{c}=0.3180\end{array}$ & 21.44 & - \\
\hline $\begin{array}{c}\left(\mathrm{Sn}_{0.95} \mathrm{Nb}_{0.05}\right) \mathrm{O}_{2}: \mathrm{N}- \\
400 \mathrm{NTs}\end{array}$ & $\begin{array}{c}a=b=0.4741 \\
c=0.3190\end{array}$ & 21.58 & 3.02 \\
\hline $\begin{array}{c}\left(\mathrm{Sn}_{0.95} \mathrm{Nb}_{0.05}\right) \mathrm{O}_{2}: \mathrm{N}- \\
500 \mathrm{NTs}\end{array}$ & $\begin{array}{c}a=b=0.4743 \\
c=0.3193\end{array}$ & 21.62 & 7.1 \\
\hline $\begin{array}{c}\left(\mathrm{Sn}_{0.95} \mathrm{Nb}_{0.05}\right) \mathrm{O}_{2}: \mathrm{N}- \\
600 \mathrm{NTs}\end{array}$ & $\begin{array}{c}\mathrm{a}=\mathrm{b}=0.4748 \\
\mathrm{c}=0.3196\end{array}$ & 21.69 & 14.01 \\
\hline
\end{tabular}


Table 2. Results of Tauc analysis, Mott-Schottky analysis and photoelectrochemical

914 characterization of $\mathrm{SnO}_{2},\left(\mathrm{Sn}_{1-\mathrm{x}} \mathrm{Nb}_{\mathrm{x}}\right) \mathrm{O}_{2}(\mathrm{x}=\mathbf{0 . 0 5}, \mathbf{0 . 1})$ and $\left(\mathrm{Sn}_{0.95} \mathrm{Nb}_{0.05}\right) \mathrm{O}_{2}: \mathrm{N}$ NTs $($ performed

915

in $0.5 \mathrm{M} \mathrm{H}_{2} \mathrm{SO}_{4}$ electrolyte solution under illumination of $100 \mathrm{~mW} \mathrm{~cm} \mathrm{ct}^{-2}$ at $26^{\circ} \mathrm{C}$ )

\begin{tabular}{|c|c|c|c|c|c|c|c|}
\hline Composition & $\begin{array}{c}\text { Band } \\
\text { gap } \\
(\mathrm{eV})\end{array}$ & $\begin{array}{c}\text { Carrier } \\
\text { density } \\
\left(\mathbf{c m}^{-3}\right)\end{array}$ & $\begin{array}{c}\text { Onset } \\
\text { potential } \\
\text { (V, } \\
\text { RHE) }\end{array}$ & $\begin{array}{c}\text { Photocurrent } \\
\text { density at } \\
0.75 \mathrm{~V}(v s \\
\text { RHE) } \\
\left.(\mathrm{mA} \mathrm{cm})^{-2}\right)\end{array}$ & $\begin{array}{c}\text { Max. } \\
\text { applied } \\
\text { bias } \\
\text { photon- } \\
\text { to- } \\
\text { current } \\
\text { efficiency } \\
\text { (ABPE) } \\
\text { (\%) }\end{array}$ & $\begin{array}{l}\text { Potential } \\
\text { corresponding } \\
\text { to max. ABPE } \\
\text { (V vs RHE) }\end{array}$ & $\begin{array}{c}\mathrm{N} \\
\text { concentration } \\
\text { (from EDAX } \\
\text { analysis) } \\
\text { (at. \%) }\end{array}$ \\
\hline $\mathrm{SnO}_{2}$ & 3.53 & $2.42 \times\left(10^{18}\right)$ & 0.28 & $\sim 0$ & 0.008 & 0.9 & - \\
\hline$\left(\mathrm{Sn}_{0.95} \mathrm{Nb}_{0.05}\right) \mathrm{O}_{2}$ & 3.1 & $4.2 \times\left(10^{19}\right)$ & 0.17 & 0.17 & 0.088 & 0.82 & - \\
\hline$\left(\mathrm{Sn}_{0.9} \mathrm{Nb}_{0.1}\right) \mathrm{O}_{2}$ & 2.99 & $5.52 \times\left(10^{19}\right)$ & 0.17 & 0.1 & 0.051 & 0.82 & - \\
\hline $\begin{array}{c}\left(\mathrm{Sn}_{0.95} \mathrm{Nb}_{0.05}\right) \mathrm{O}_{2}: \mathrm{N}- \\
400 \mathrm{NTs}\end{array}$ & 2.58 & $3.3 \times\left(10^{22}\right)$ & $(-0.02)$ & 6.76 & 1.83 & 0.78 & 3.02 \\
\hline $\begin{array}{c}\left(\mathrm{Sn}_{0.95} \mathrm{Nb}_{0.05}\right) \mathrm{O}_{2}: \mathrm{N}- \\
500 \mathrm{NTs}\end{array}$ & 2.38 & $4.05 \times\left(10^{22}\right)$ & $(-0.02)$ & 11.74 & 2.29 & 0.78 & 7.1 \\
\hline $\begin{array}{c}\left(\mathrm{Sn}_{0.95} \mathrm{Nb}_{0.05}\right) \mathrm{O}_{2}: \mathrm{N}- \\
600 \mathrm{NTs}\end{array}$ & 1.99 & $4.7 \times\left(10^{22}\right)$ & $(-0.14)$ & 25.39 & 4.1 & 0.75 & 14.01 \\
\hline
\end{tabular}

916 
Table 3. Results of EIS analysis of $\mathrm{SnO}_{2},\left(\mathrm{Sn}_{1-\mathrm{x}} \mathrm{Nb}_{\mathrm{x}}\right) \mathrm{O}_{2}(\mathrm{x}=\mathbf{0 . 0 5}, \mathbf{0 . 1})$ and $\left(\mathrm{Sn}_{0.95} \mathrm{Nb}_{0.05}\right) \mathrm{O}_{2}: \mathrm{N}$

919 NTs performed at $0.75 \mathrm{~V}(\mathrm{RHE})$ in $0.5 \mathrm{M} \mathrm{H}_{2} \mathrm{SO}_{4}$ electrolyte solution in frequency range of $100 \mathrm{mHz}-100 \mathrm{kHz}$ under illumination $\left(100 \mathrm{~mW} \mathrm{~cm}^{-2}\right)$ at $26^{0} \mathrm{C}$

\begin{tabular}{|c|c|c|c|}
\hline Composition & $R_{\mathrm{s}}\left(\Omega . \mathrm{cm}^{2}\right)$ & $R_{e}\left(\Omega . c^{2}\right)$ & $\mathbf{R}_{\mathrm{ct}}\left(\Omega . \mathrm{cm}^{2}\right)$ \\
\hline$\overline{\mathrm{SnO}_{2}}$ & 15.16 & 6.49 & 92 \\
\hline$\left(\mathrm{Sn}_{0.95} \mathrm{Nb}_{0.05}\right) \mathrm{O}_{2}$ & 15.18 & 6.47 & 68.2 \\
\hline$\left(\mathrm{Sn}_{0.9} \mathrm{Nb}_{0.1}\right) \mathrm{O}_{2}$ & 15.18 & 6.45 & 84.2 \\
\hline $\begin{array}{c}\left(\mathrm{Sn}_{0.95} \mathrm{Nb}_{0.05}\right) \mathrm{O}_{2}: \mathrm{N}- \\
400 \mathrm{NTs}\end{array}$ & 15.17 & 6.43 & 24.6 \\
\hline $\begin{array}{c}\left(\mathrm{Sn}_{0.95} \mathrm{Nb}_{0.05}\right) \mathrm{O}_{2}: \mathrm{N}- \\
500 \mathrm{NTs}\end{array}$ & 15.16 & 6.41 & 19.2 \\
\hline $\begin{array}{c}\left(\mathrm{Sn}_{0.95} \mathrm{Nb}_{0.05}\right) \mathrm{O}_{2}: \mathrm{N}- \\
600 \mathrm{NTs}\end{array}$ & 15.17 & 6.38 & 15.3 \\
\hline
\end{tabular}

Table 4. Calculated and experimental values of optical band gap $\left(E_{B G}\right)$ of pure and doped $\mathrm{SnO}_{2}$

\begin{tabular}{|c|c|c|}
\hline Composition & $\begin{array}{c}\text { Calculated E } \\
\mathbf{B G} \\
(\mathbf{e V})\end{array}$ & $\begin{array}{c}\text { Experimental } \\
\mathbf{E}_{\mathbf{B G}}(\mathbf{e V})\end{array}$ \\
\hline $\mathbf{S n O}_{\mathbf{2}}$ & 1.12 & 3.53 \\
\hline$\left(\mathbf{S n}_{\mathbf{0 . 9 4}} \mathbf{N b}_{\mathbf{0 . 0 6}}\right) \mathbf{O}_{\mathbf{2}}$ & 1.08 & 3.1 \\
\hline $\mathbf{S n}\left(\mathbf{O}_{\mathbf{1 . 9 7}} \mathbf{N}_{\mathbf{0 . 0 3}}\right)$ & 0.80 & - \\
\hline$\left(\mathbf{S n}_{\mathbf{0 . 9 4}} \mathbf{N b}_{\mathbf{0 . 0 6}}\right)\left(\mathbf{O}_{\mathbf{1 . 9 7}} \mathbf{N}_{\mathbf{0 . 0 3}}\right)$ & 0.93 & 2.58 \\
\hline$\left(\mathbf{S n}_{\mathbf{0 . 9 4}} \mathbf{N b}_{\mathbf{0 . 0 6}}\right)\left(\mathbf{O}_{\mathbf{1 . 9 4}} \mathbf{N}_{\mathbf{0 . 0 6}}\right)$ & 0.91 & 2.38 \\
\hline$\left(\mathbf{S n}_{\mathbf{0 . 9 4}} \mathbf{N b}_{\mathbf{0 . 0 6}}\right)\left(\mathbf{O}_{\mathbf{1 . 8 7 5}} \mathbf{N}_{\mathbf{0 . 1 2 5}}\right)$ & 0.87 & 1.99 \\
\hline
\end{tabular}


925 Figure 1. The XRD patterns of pure $\mathrm{SnO}_{2} \mathrm{NTs}$ and $\left(\mathrm{Sn}_{1-\mathrm{x}} \mathrm{Nb}_{\mathrm{x}}\right) \mathrm{O}_{2} \mathrm{NTs}(\mathrm{x}=0.05,0.1)$ in wide 926 angle $2 \theta$ scan

Figure 2. (a) UV-vis absorption spectra of $\mathrm{SnO}_{2} \mathrm{NTs}$ and $\left(\mathrm{Sn}_{1-\mathrm{x}} \mathrm{Nb}_{\mathrm{x}}\right) \mathrm{O}_{2} \mathrm{NTs}(\mathrm{x}=0.05,0.1)$, (b)

928 Tauc analysis of $\mathrm{SnO}_{2} \mathrm{NTs}$ and $\left(\mathrm{Sn}_{1-\mathrm{x}} \mathrm{Nb}_{\mathrm{x}}\right) \mathrm{O}_{2}$ NTs $(\mathrm{x}=0.05,0.1)$, (c) Mott-Schottky plot of $\mathrm{SnO}_{2}$ 929 NTs and $\left(\mathrm{Sn}_{1-\mathrm{x}} \mathrm{Nb}_{\mathrm{x}}\right) \mathrm{O}_{2} \mathrm{NTs}(\mathrm{x}=0.05,0.1)$, (d) The linear scan voltammogram (LSV) curves for $930 \mathrm{SnO}_{2}$ NTs and $\left(\mathrm{Sn}_{1-\mathrm{x}} \mathrm{Nb}_{\mathrm{x}}\right) \mathrm{O}_{2} \mathrm{NTs}(\mathrm{x}=0.05,0.1)$ in dark and under illumination of $100 \mathrm{~mW}_{\mathbf{~ c m}}^{-2}$ 931 in $0.5 \mathrm{M} \mathrm{H}_{2} \mathrm{SO}_{4}$ at $26^{\circ} \mathrm{C}$, before and after $\mathrm{iR}_{\Omega}$ correction, (e) Applied bias photon-to-current 932 efficiency (ABPE) as a function of applied potential for $\mathrm{SnO}_{2} \mathrm{NTs}$ and $\left(\mathrm{Sn}_{1-\mathrm{x}} \mathrm{Nb}_{\mathrm{x}}\right) \mathrm{O}_{2} \mathrm{NTs}$ $933(\mathrm{x}=0.05,0.1), \quad(\mathrm{f}) \quad \mathrm{EIS}$ spectra of $\mathrm{SnO}_{2} \quad \mathrm{NTs}, \quad\left(\mathrm{Sn}_{1-\mathrm{x}} \mathrm{Nb}_{\mathrm{x}}\right) \mathrm{O}_{2}$ NTs $(\mathrm{x}=0.05,0.1)$ and $934\left(\mathrm{Sn}_{0.95} \mathrm{Nb}_{0.05}\right) \mathrm{O}_{2}: \mathrm{N}$ NTs of different $\mathrm{N}$ concentration obtained at $0.75 \mathrm{~V}$ (vs RHE) in $0.5 \mathrm{M} \mathrm{H}_{2} \mathrm{SO}_{4}$ 935 at $26^{\circ} \mathrm{C}$ in the frequency range of $100 \mathrm{mHz}$ to $100 \mathrm{kHz}$ under illumination $\left(100 \mathrm{~mW} \mathbf{c m}^{-2}\right)$ with 936 the circuit used for fitting experimental data

937 Figure 3. (a) The XRD patterns of pure $\mathrm{SnO}_{2} \mathrm{NTs}$ and $\left(\mathrm{Sn}_{0.95} \mathrm{Nb}_{0.05}\right) \mathrm{O}_{2}: \mathrm{N}$ NTs of different $\mathrm{N}$ 938 concentration in wide angle $2 \theta$ scan, (b) The magnified view of XRD patterns of pure $\mathrm{SnO}_{2} \mathrm{NTs}$ 939 and $\left(\mathrm{Sn}_{0.95} \mathrm{Nb}_{0.05}\right) \mathrm{O}_{2}: \mathrm{N}$ NTs of different $\mathrm{N}$ concentration, (c) SEM micrograph showing top 940 image, cross-sectional image and EDAX spectrum of $\left(\mathrm{Sn}_{0.95} \mathrm{Nb}_{0.05}\right) \mathrm{O}_{2}: \mathrm{N}-600 \mathrm{NTs}$, (d) The bright 941 field TEM images of $\left(\mathrm{Sn}_{0.95} \mathrm{Nb}_{0.05}\right) \mathrm{O}_{2}: \mathrm{N}-600$ NTs showing hollow nanotubes of diameter $~ 180$ $942 \quad 220 \mathrm{~nm}$

943 Figure 4. The XPS spectra of $\left(\mathrm{Sn}_{0.95} \mathrm{Nb}_{0.05}\right) \mathrm{O}_{2}: \mathrm{N}$ NTs showing (a) Sn $3 \mathrm{~d}_{3 / 2}$ and $3 \mathrm{~d}_{5 / 2}$ doublet, (b) $944 \mathrm{~N} 1 \mathrm{~s}$ peak and (c) $\mathrm{Nb} 3 \mathrm{~d}_{3 / 2}$ and $3 \mathrm{~d}_{5 / 2}$ doublet 
945 Figure 5. (a) UV-vis absorption spectra of $\left(\mathrm{Sn}_{1-\mathrm{x}} \mathrm{Nb}_{\mathrm{x}}\right) \mathrm{O}_{2} \mathrm{NTs}(\mathrm{x}=0.05)$ and $\left(\mathrm{Sn}_{0.95} \mathrm{Nb}_{0.05}\right) \mathrm{O}_{2}: \mathrm{N}$

946 NTs of different $\mathrm{N}$ concentration, (b) Tauc analysis of $\left(\mathrm{Sn}_{0.95} \mathrm{Nb}_{0.05}\right) \mathrm{O}_{2}: \mathrm{N}$ NTs of different $\mathrm{N}$

947 concentration, (c) Mott-Schottky plots of $\left(\mathrm{Sn}_{0.95} \mathrm{Nb}_{0.05}\right) \mathrm{O}_{2}: \mathrm{N}$ NTs of different $\mathrm{N}$ concentration

948 Figure 6. (a) IPCE spectra of $\left(\mathrm{Sn}_{0.95} \mathrm{Nb}_{0.05}\right) \mathrm{O}_{2}: \mathrm{N}$ NTs of different $\mathrm{N}$ concentration measured at 949 potential of $\sim 0 \mathrm{~V}$ ( $v s$ RHE), (b) The linear scan voltammogram (LSV) curves for $950\left(\mathrm{Sn}_{0.95} \mathrm{Nb}_{0.05}\right) \mathrm{O}_{2}: \mathrm{N}$ NTs of different $\mathrm{N}$ concentration in dark and illumination of $100 \mathrm{~mW} \mathbf{c m}^{\mathbf{- 2}}$ 951 measured in $0.5 \mathrm{M} \mathrm{H}_{2} \mathrm{SO}_{4}$ at $26^{\circ} \mathrm{C}$, before and after $\mathrm{iR}_{\Omega}$ correction, (c) Applied bias photon-to952 current efficiency $(\mathrm{ABPE})$ as a function of applied potential for $\left(\mathrm{Sn}_{0.95} \mathrm{Nb}_{0.05}\right) \mathrm{O}_{2}: \mathrm{N}$ NTs of 953 different $\mathrm{N}$ concentration

954 Figure 7. (a) The variation of photocurrent density vs time in the chronoamperometry test of $955\left(\mathrm{Sn}_{0.95} \mathrm{Nb}_{0.05}\right) \mathrm{O}_{2}: \mathrm{N}-600 \mathrm{NTs}$, performed in $0.5 \mathrm{M} \mathrm{H}_{2} \mathrm{SO}_{4}$ solution under a constant potential of $9560.75 \mathrm{~V}$ (vs RHE) at $26^{0} \mathrm{C}$ for $24 \mathrm{~h}$ under illumination $\left(100 \mathrm{~mW} \mathrm{~cm}^{-2}\right)$, (b) The linear scan 957 voltammogram (LSV) curve for $\left(\mathrm{Sn}_{0.95} \mathrm{Nb}_{0.05}\right) \mathrm{O}_{2}: \mathrm{N}-600 \mathrm{NTs}$ in dark and under illumination of $958100 \mathrm{~mW} \mathbf{c m}^{-2}$ measured in $0.5 \mathrm{M} \mathrm{H}_{2} \mathrm{SO}_{4}$ at $26^{0} \mathrm{C}$, obtained before and after $24 \mathrm{~h}$ 959 chronoamperometry test

960

961

962 963 for zero

Figure 8. (a) Projected density of states for pure $\mathrm{SnO}_{2}, \mathrm{SnO}_{2}$ doped with 6.25 at $\%$ of $\mathrm{Nb}, \mathrm{SnO}_{2}$ doped with 3.125 at\% of N. Fermi level is set for zero, (b) Projected density of states for $\left(\mathrm{Sn}_{0.94} \mathrm{Nb}_{0.06}\right)\left(\mathrm{O}_{1.97} \mathrm{~N}_{0.03}\right),\left(\mathrm{Sn}_{0.94} \mathrm{Nb}_{0.06}\right)\left(\mathrm{O}_{1.94} \mathrm{~N}_{0.06}\right),\left(\mathrm{Sn}_{0.94} \mathrm{Nb}_{0.06}\right)\left(\mathrm{O}_{1.875} \mathrm{~N}_{0.125}\right)$. Fermi level is set 


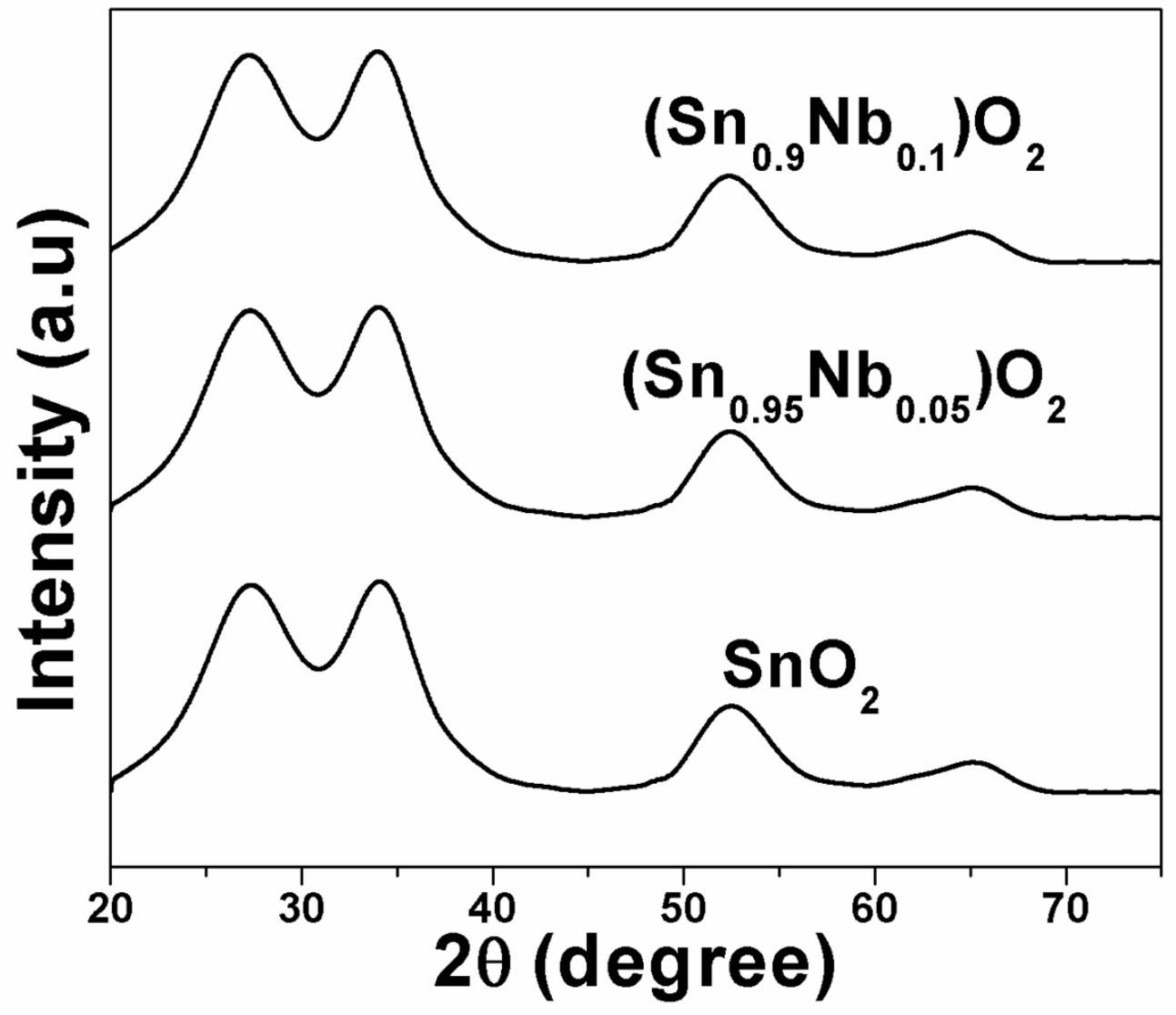

968

970

971 


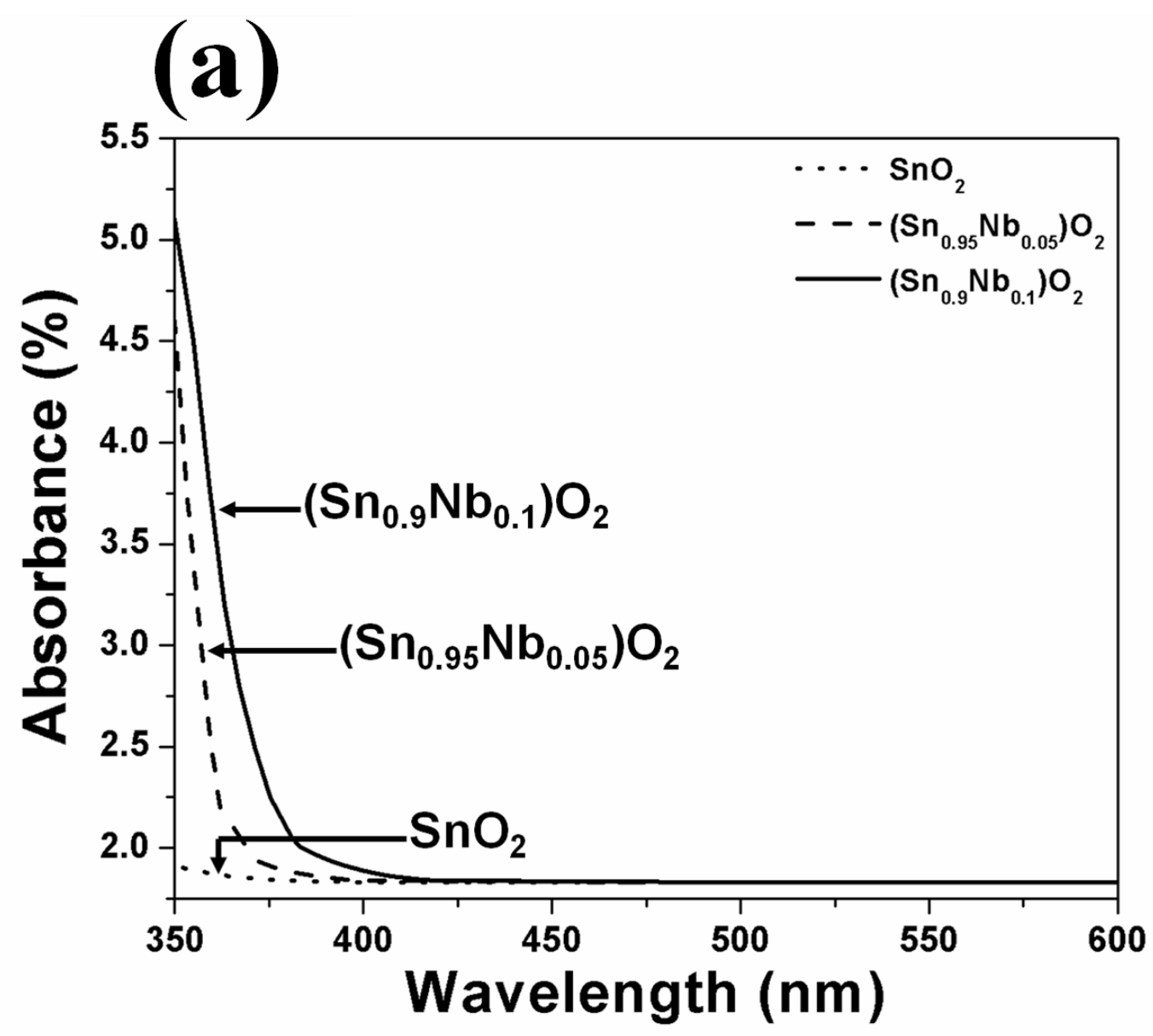

972

973

Figure 2a

974

975

976

977 


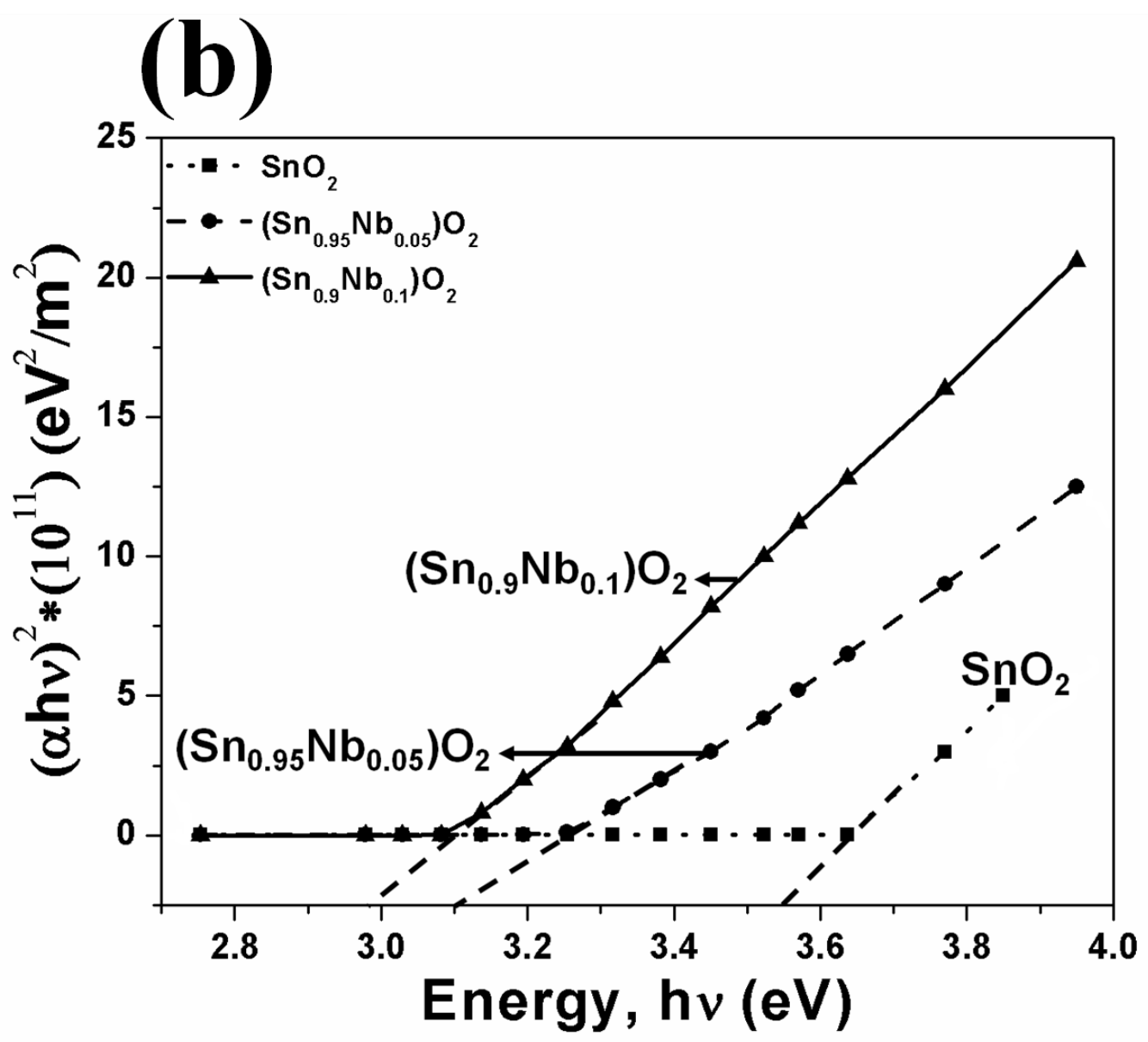

978

979

Figure 2b 


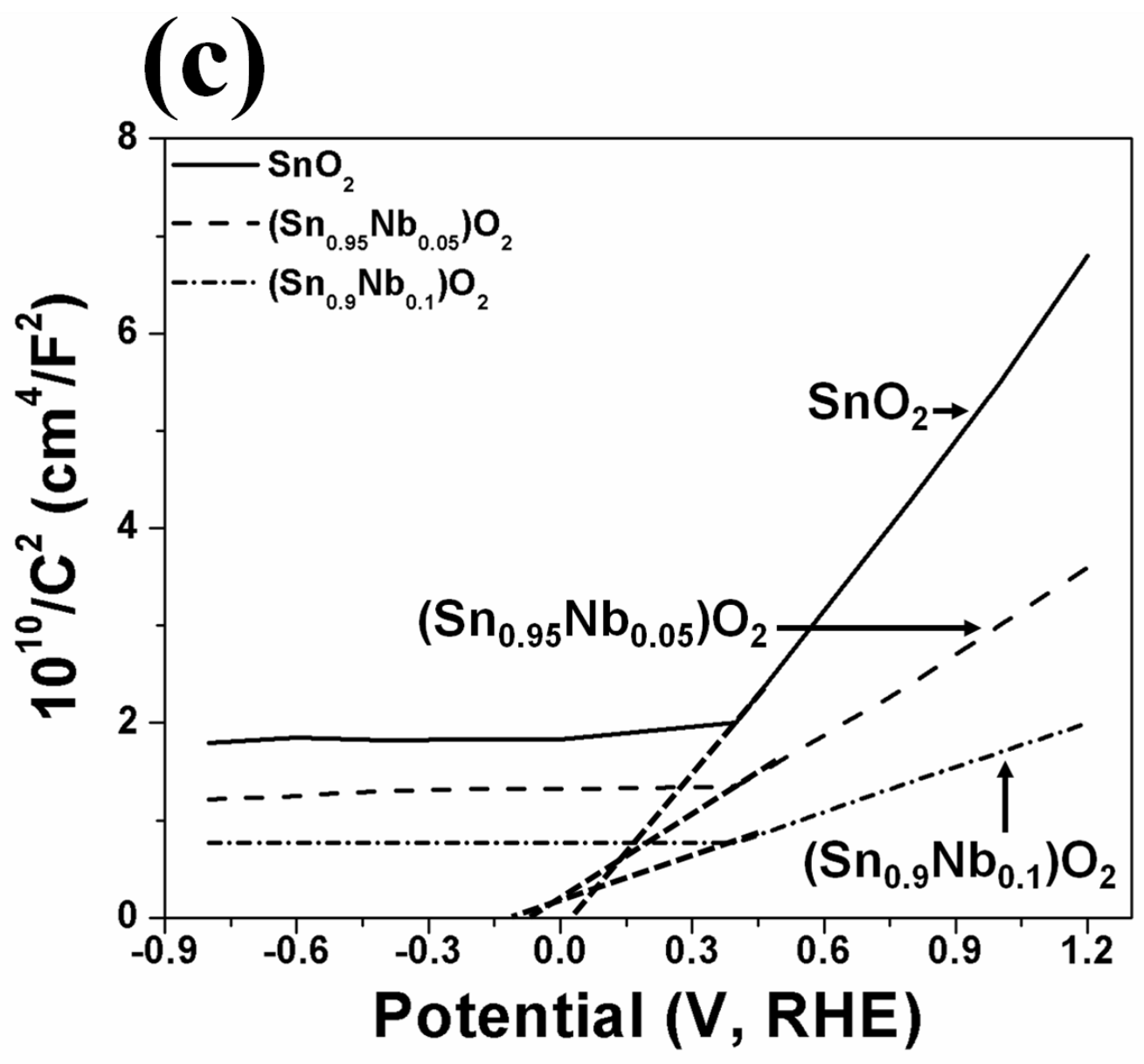

980

Figure 2c

982

983

984

985 


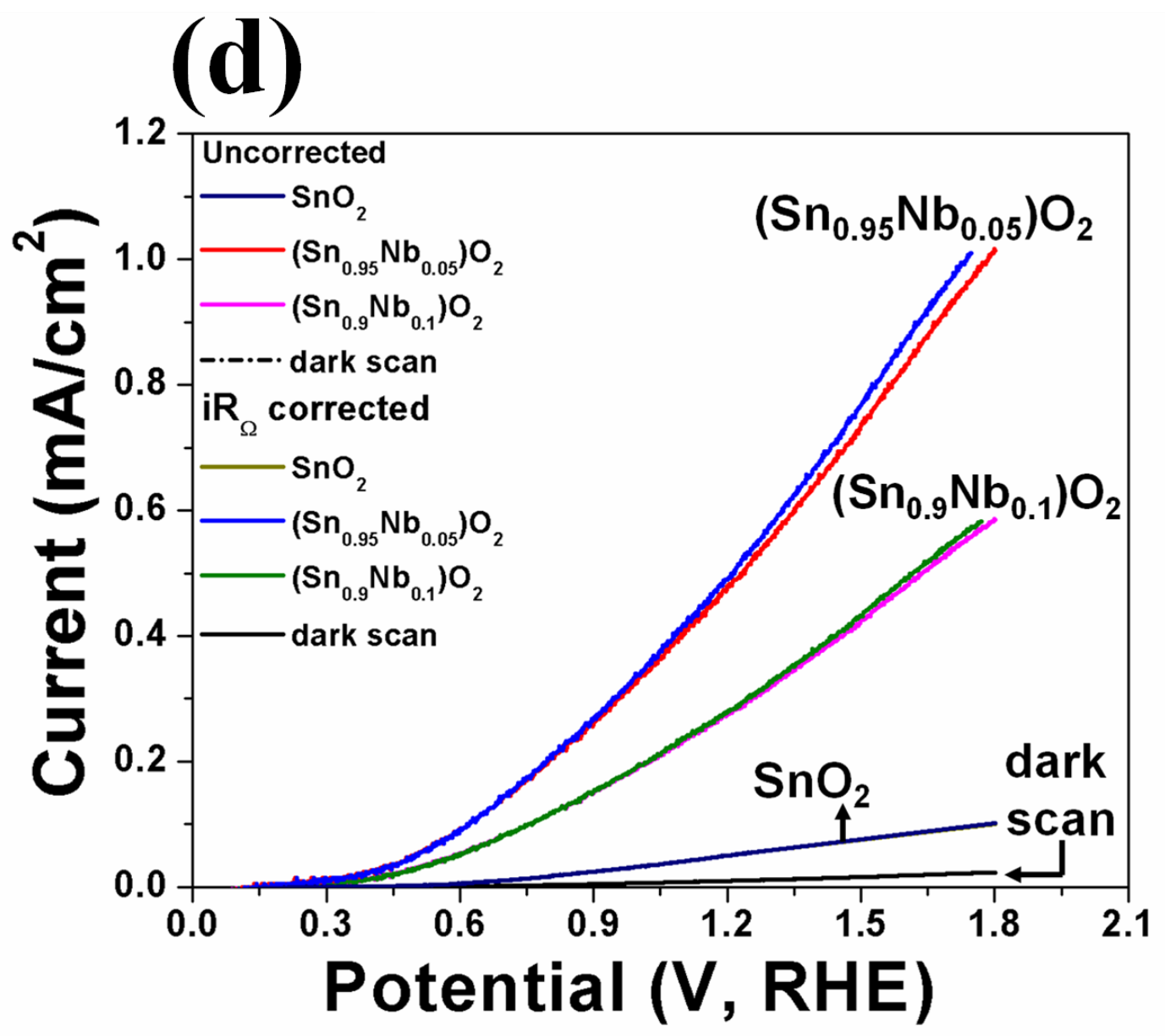




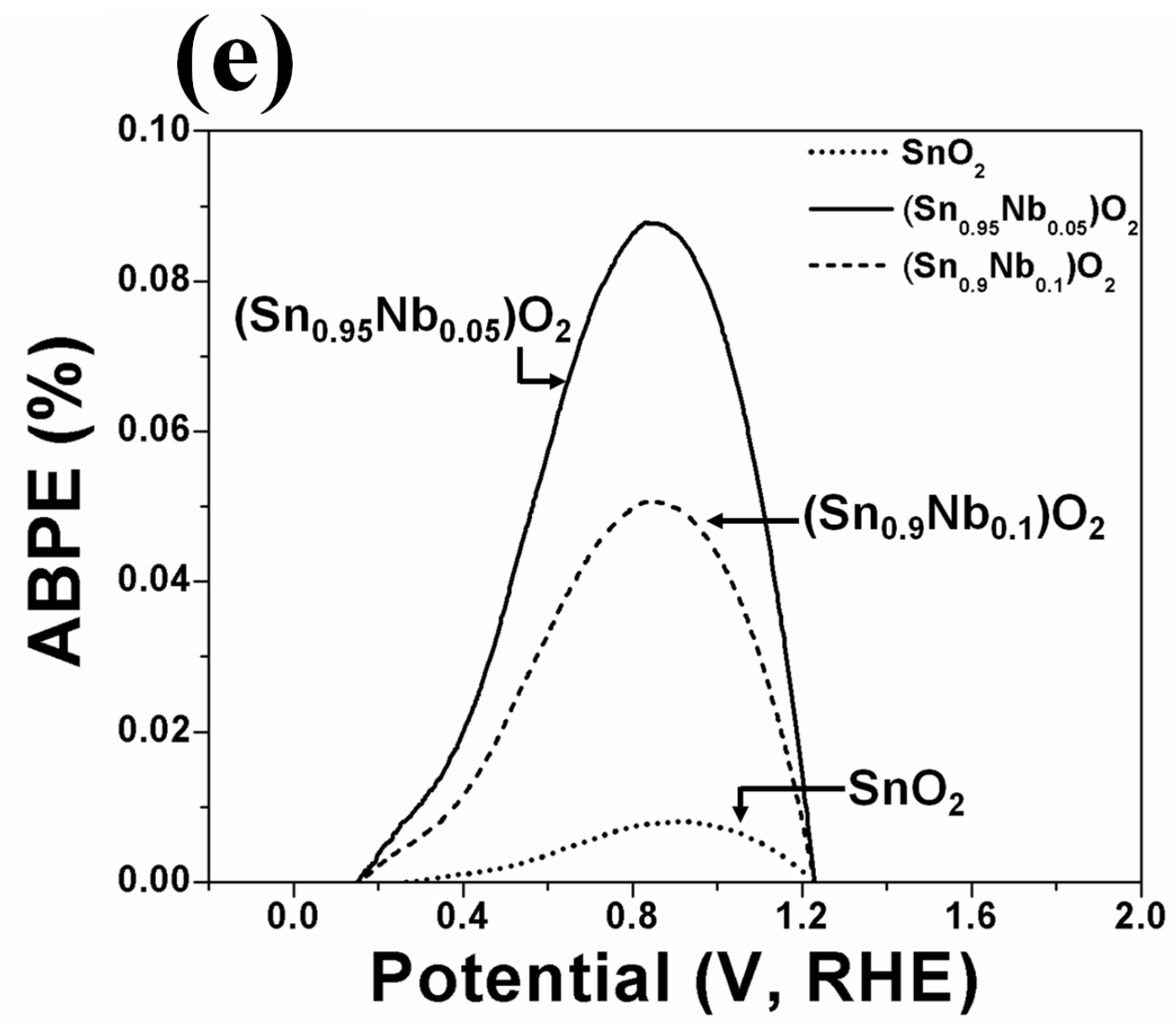

Figure 2e

992 


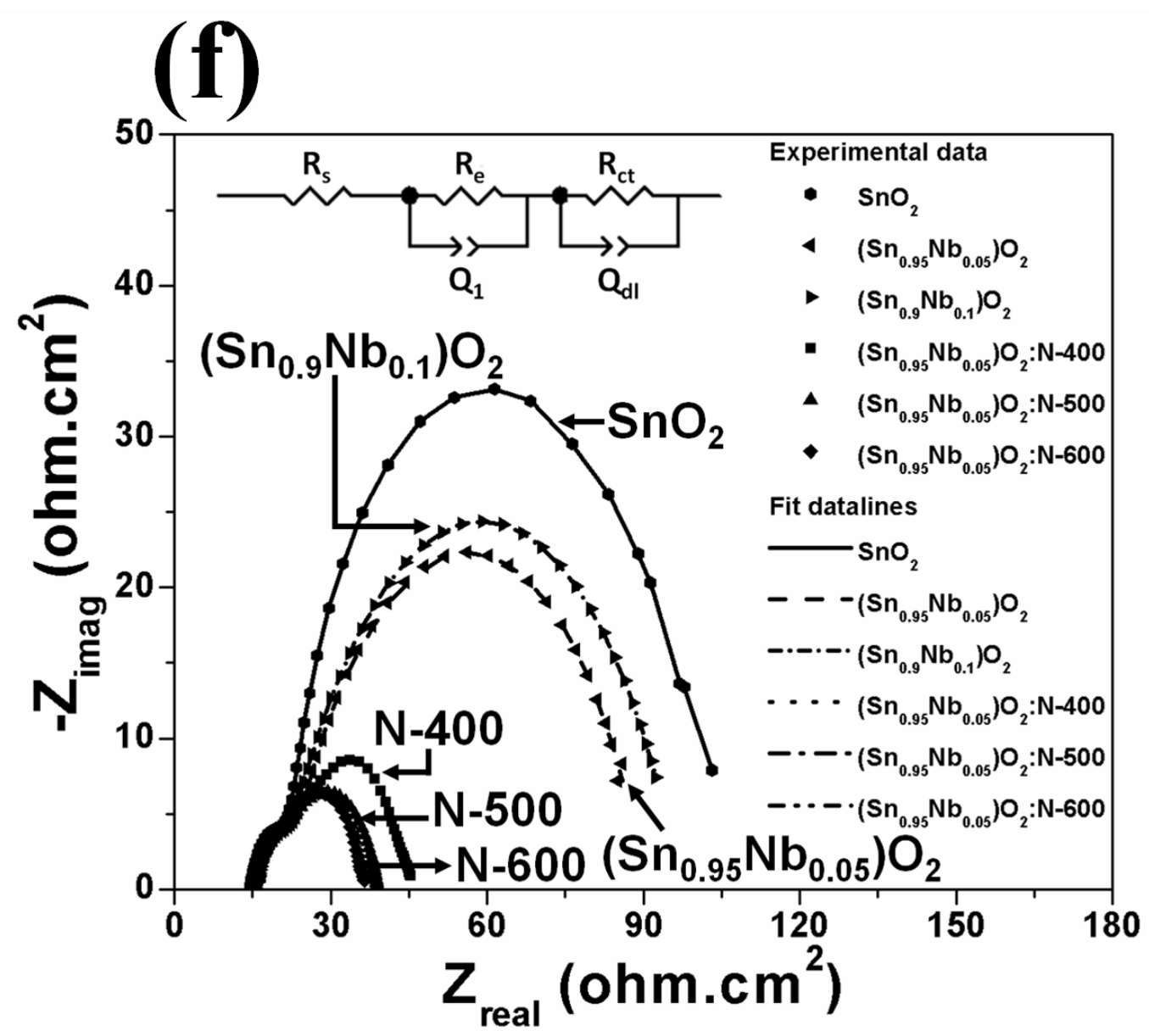




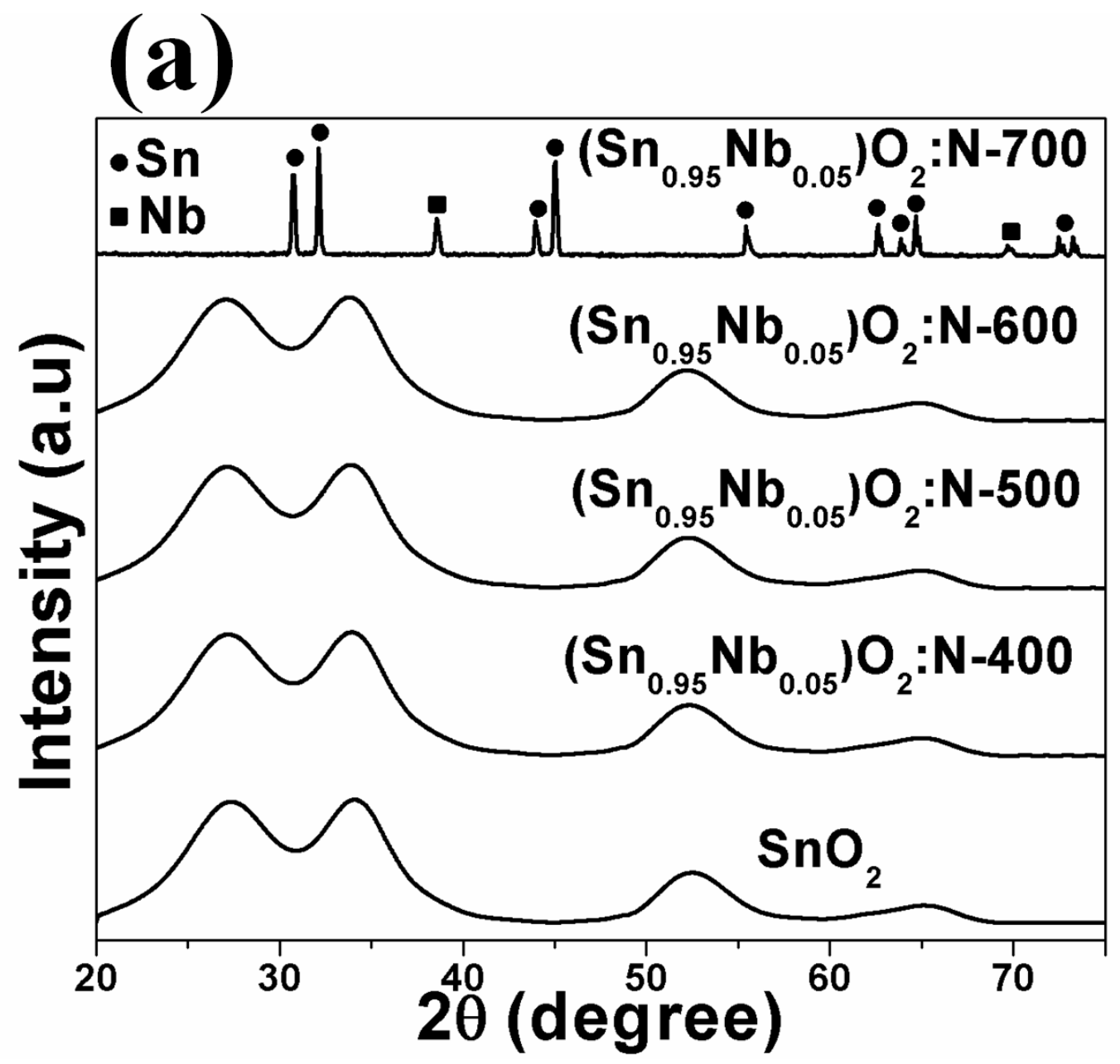

997

Figure 3a

998

999 


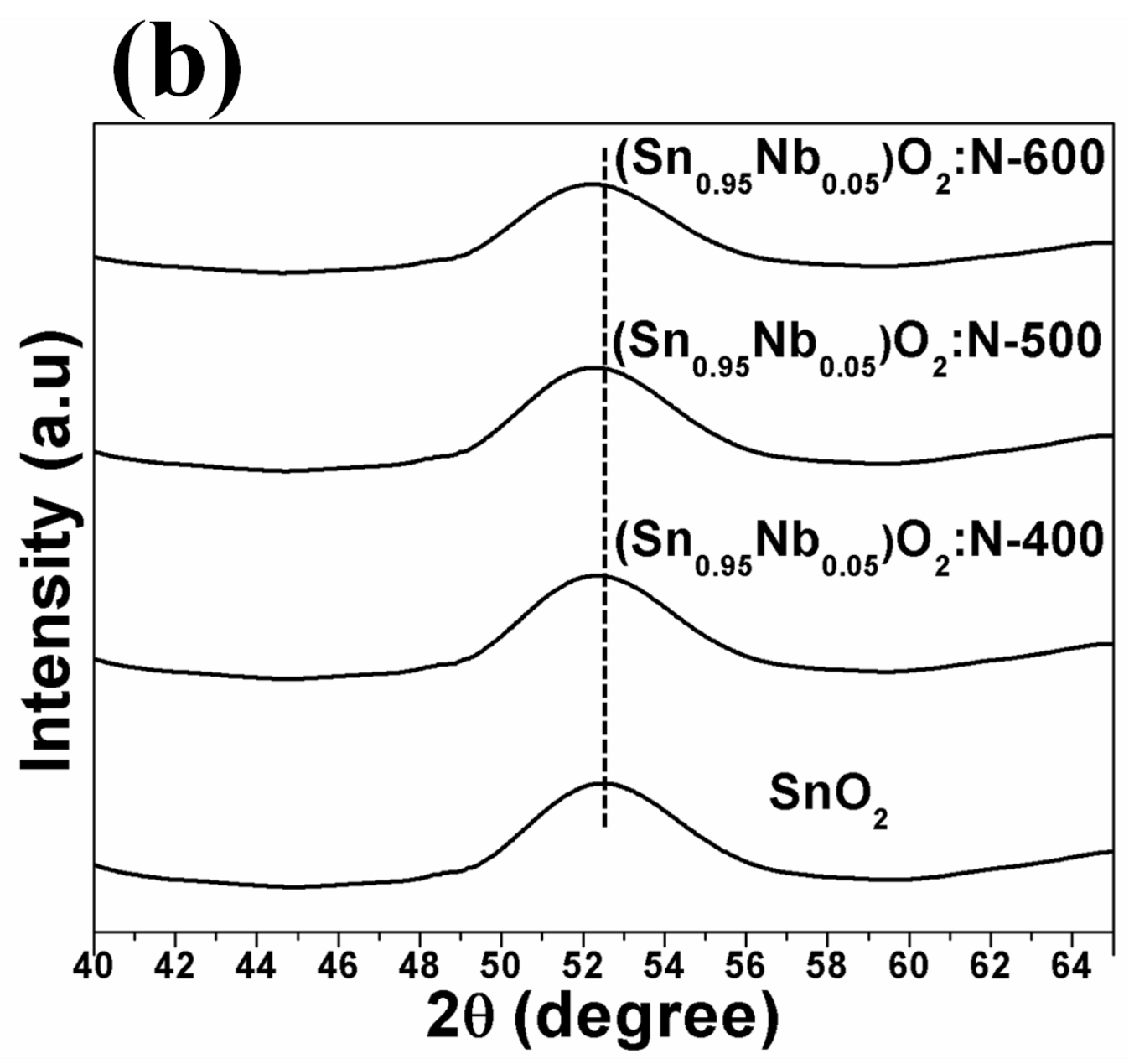

1001

Figure 3b

1002

1003

1004 

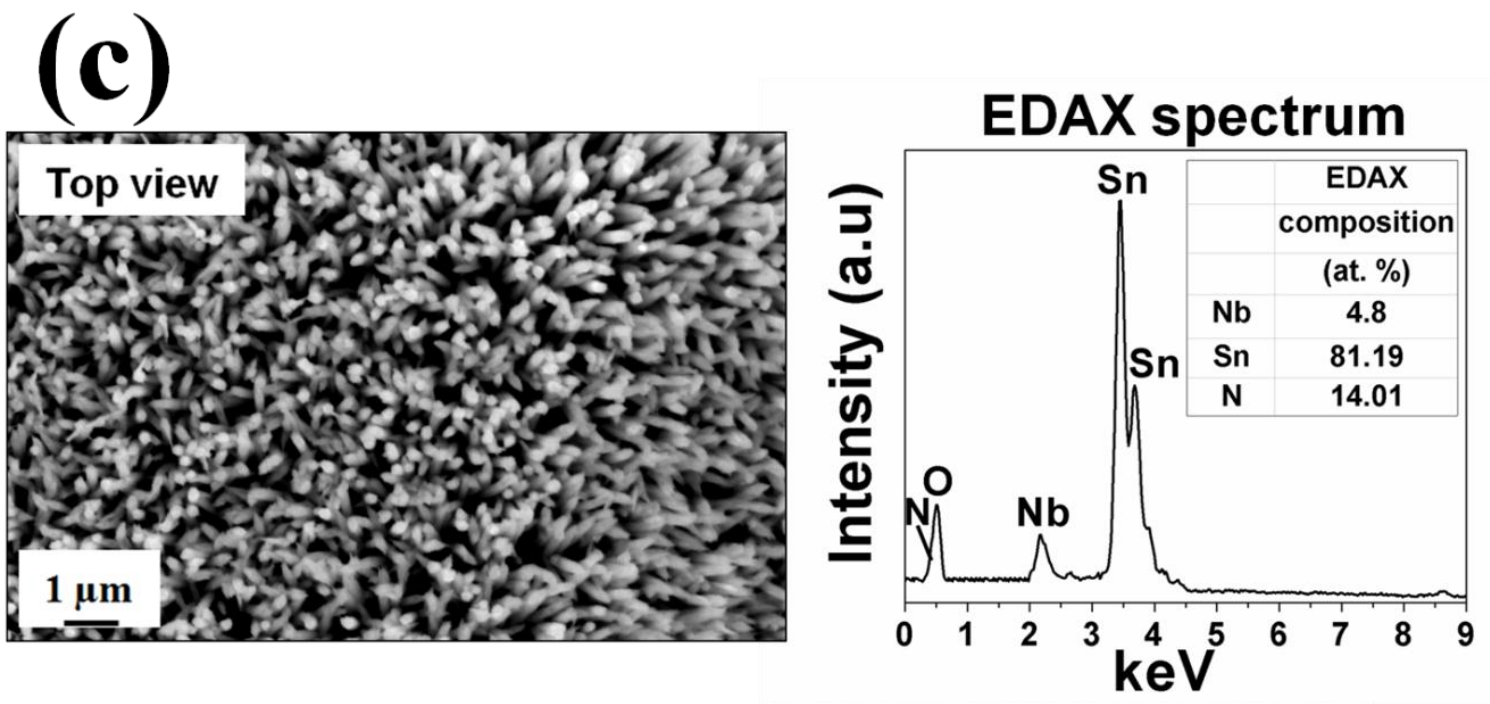

1005

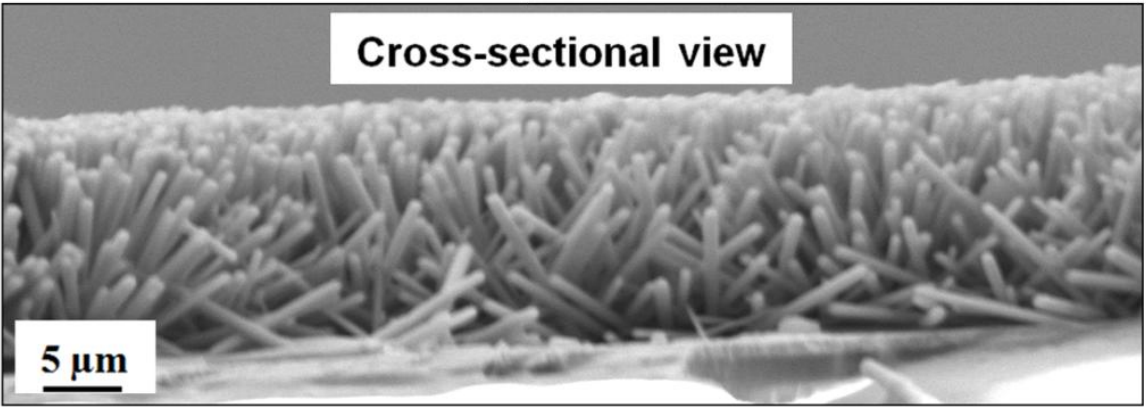

1006

Figure 3c

1007

1008

1009 


\section{(d)}

1010

1011

1012

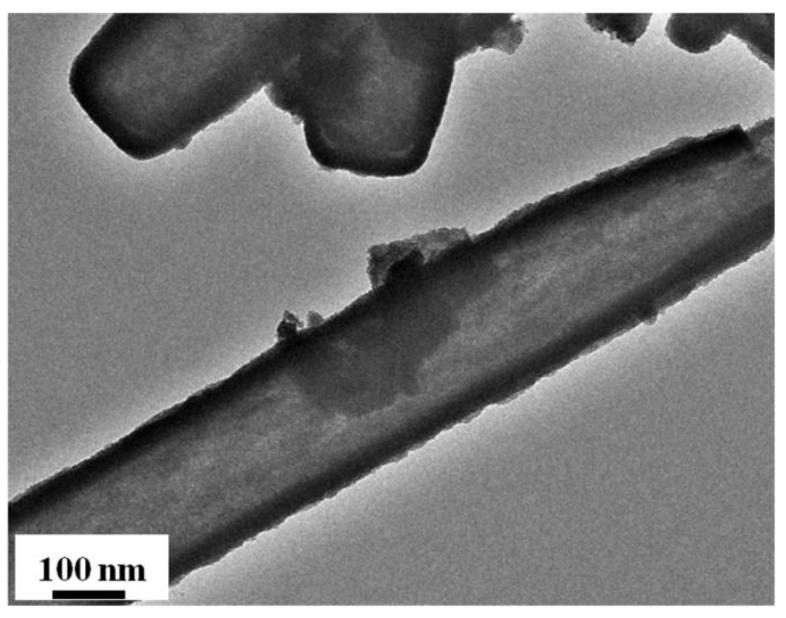

Figure 3d 
1013

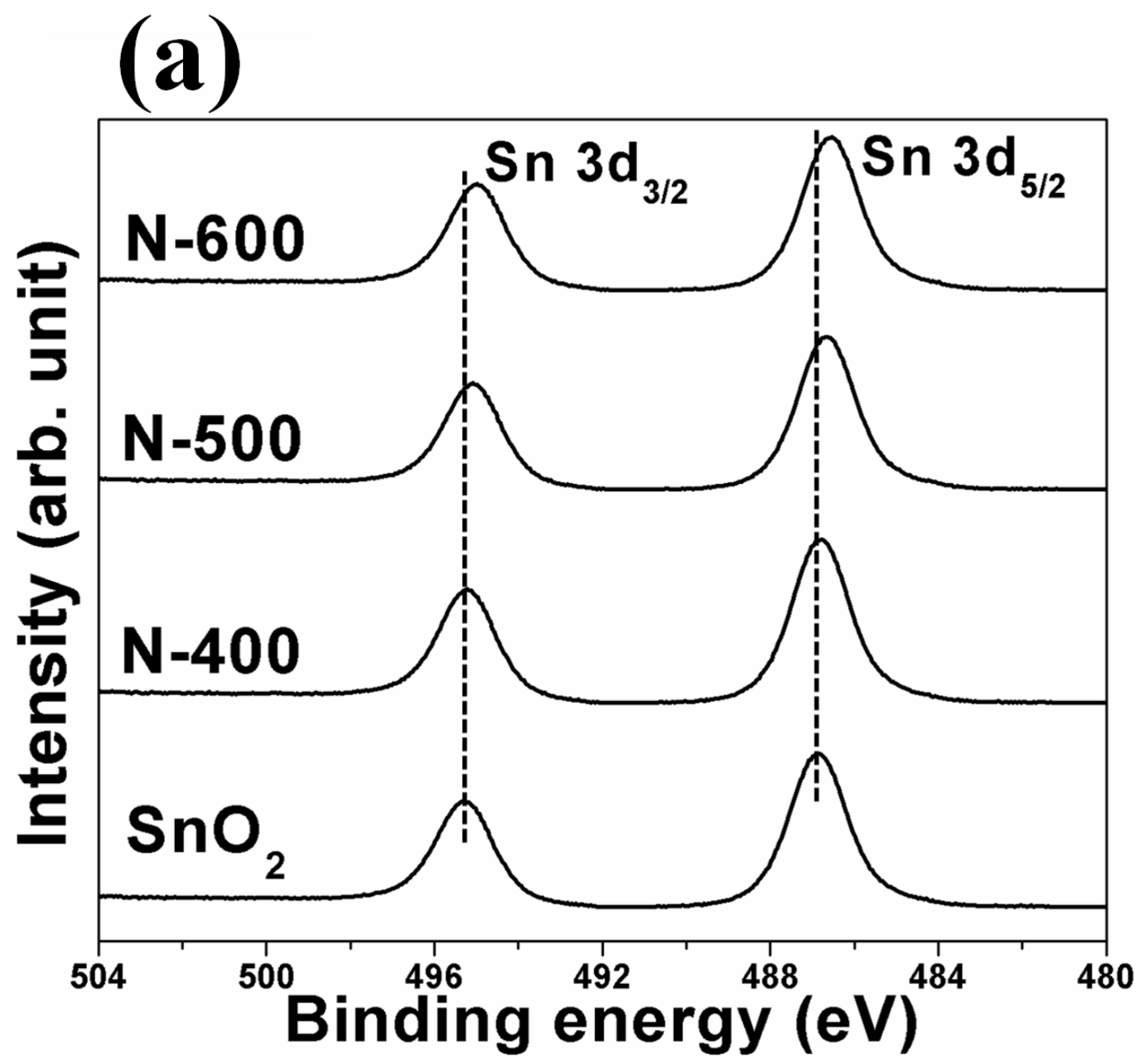

1014

1015

Figure 4a

1016

1017 


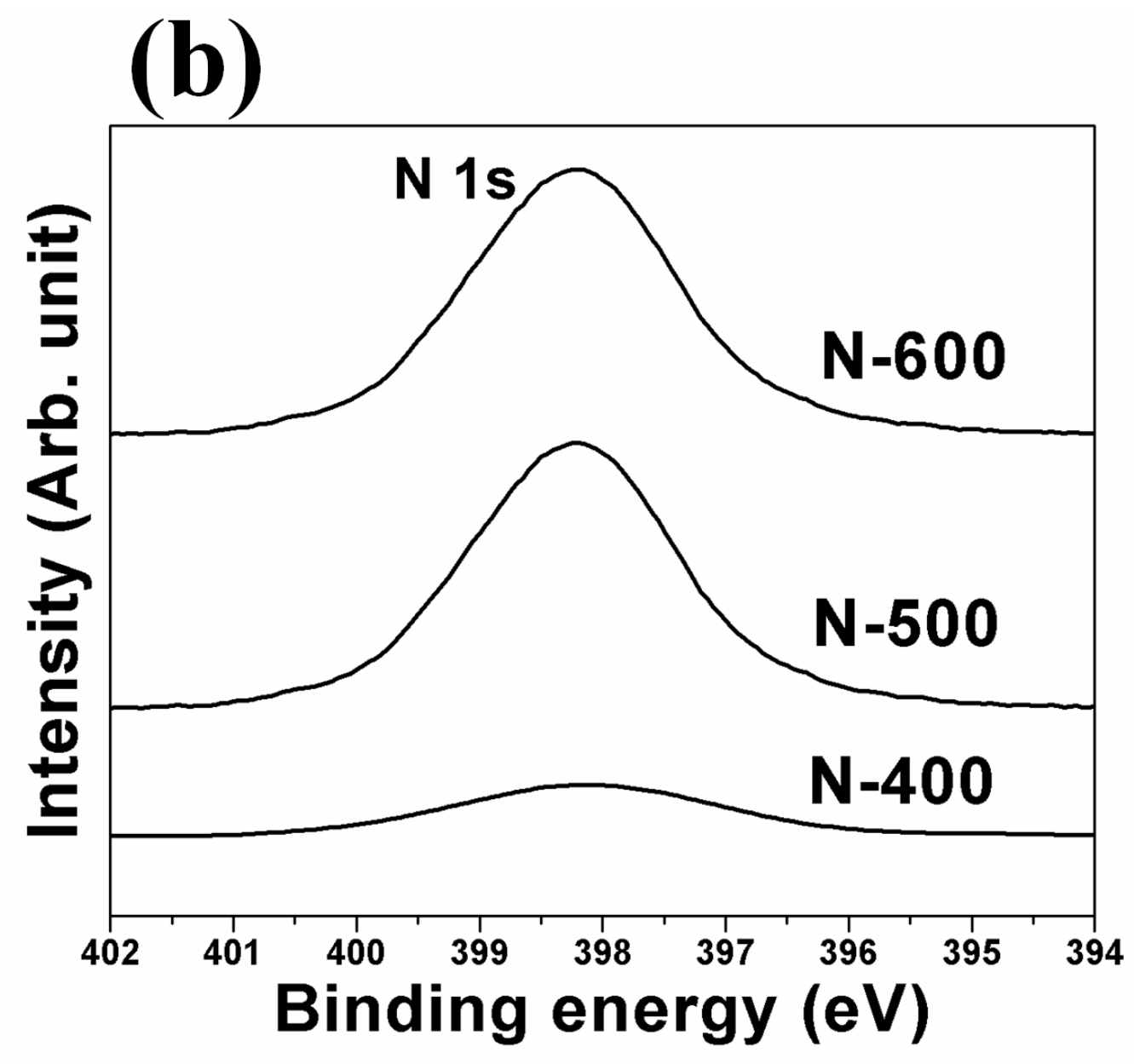

1018

1019

Figure 4b

1020

1021 


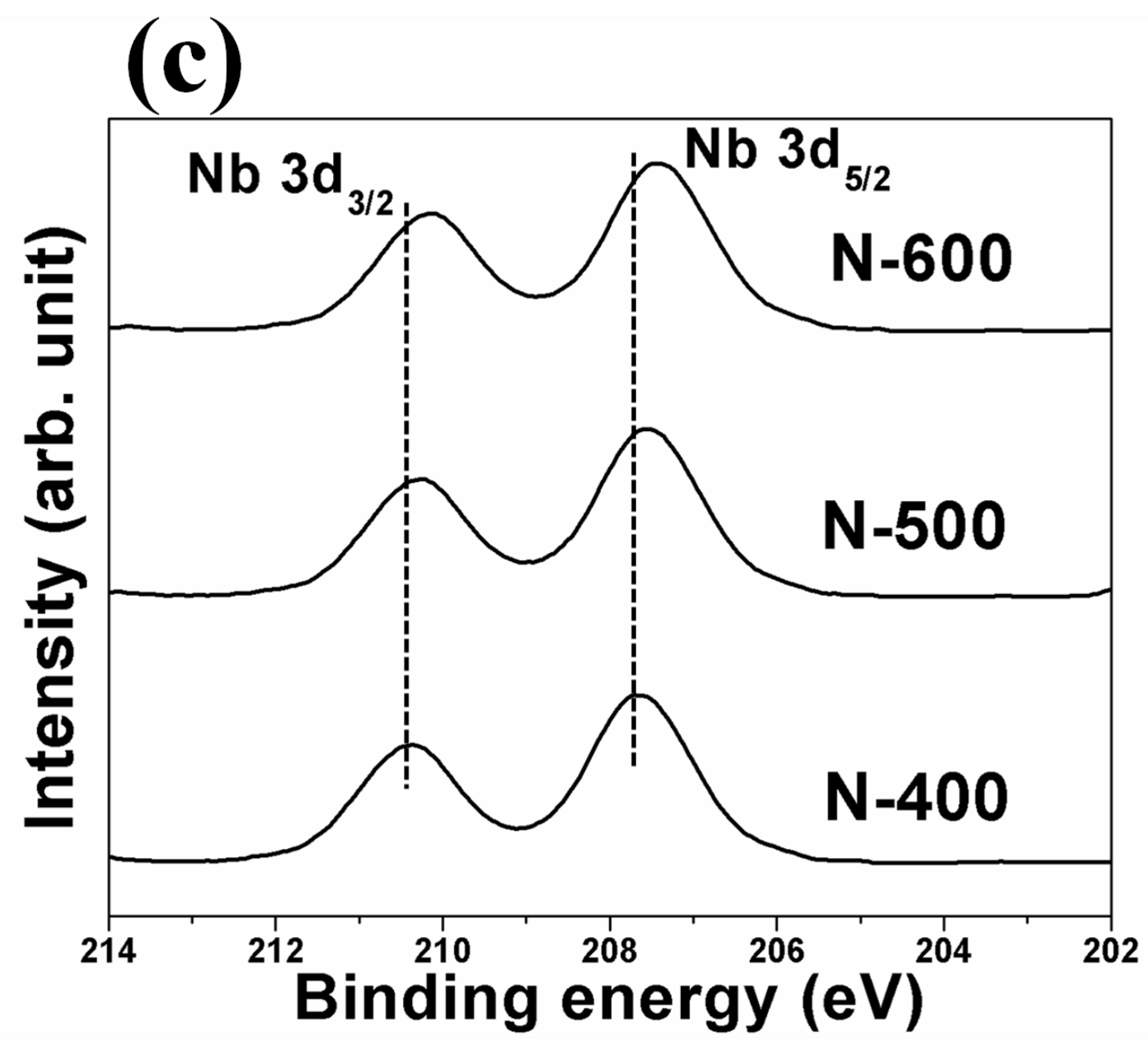

1023

Figure 4c

1024

1025

1026

1027 


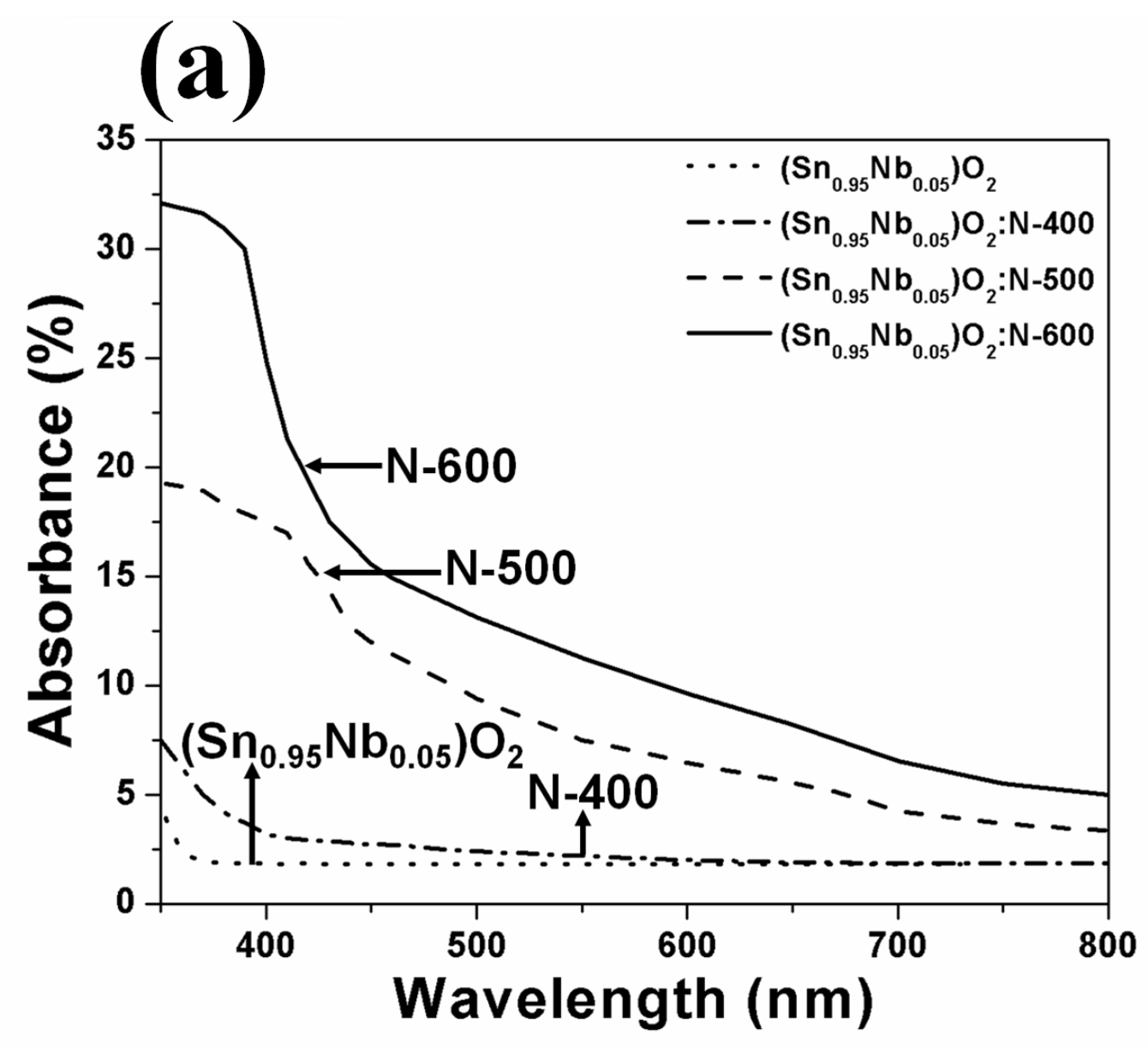

1028

1029

Figure 5a

1030

1031 


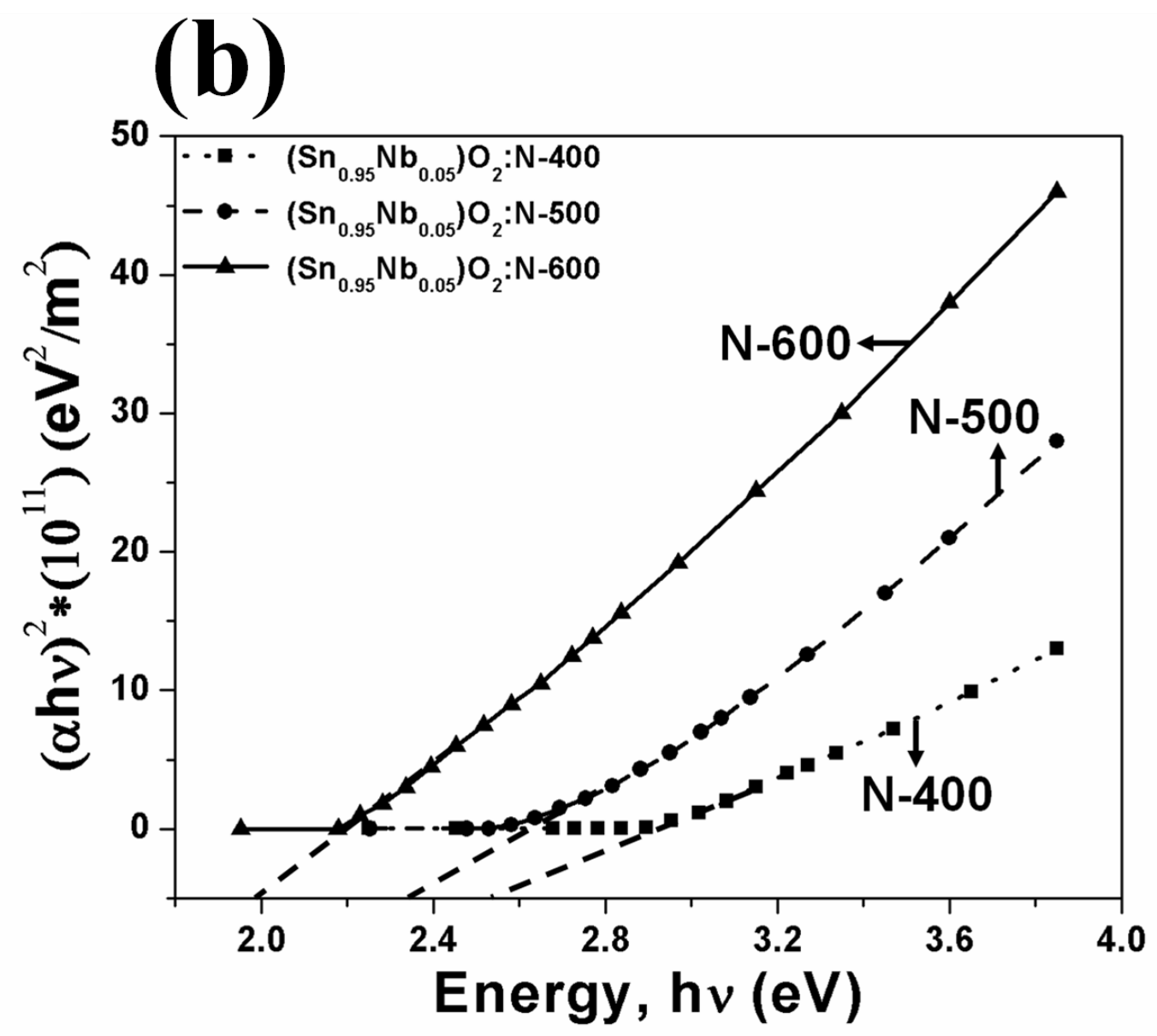

1032 


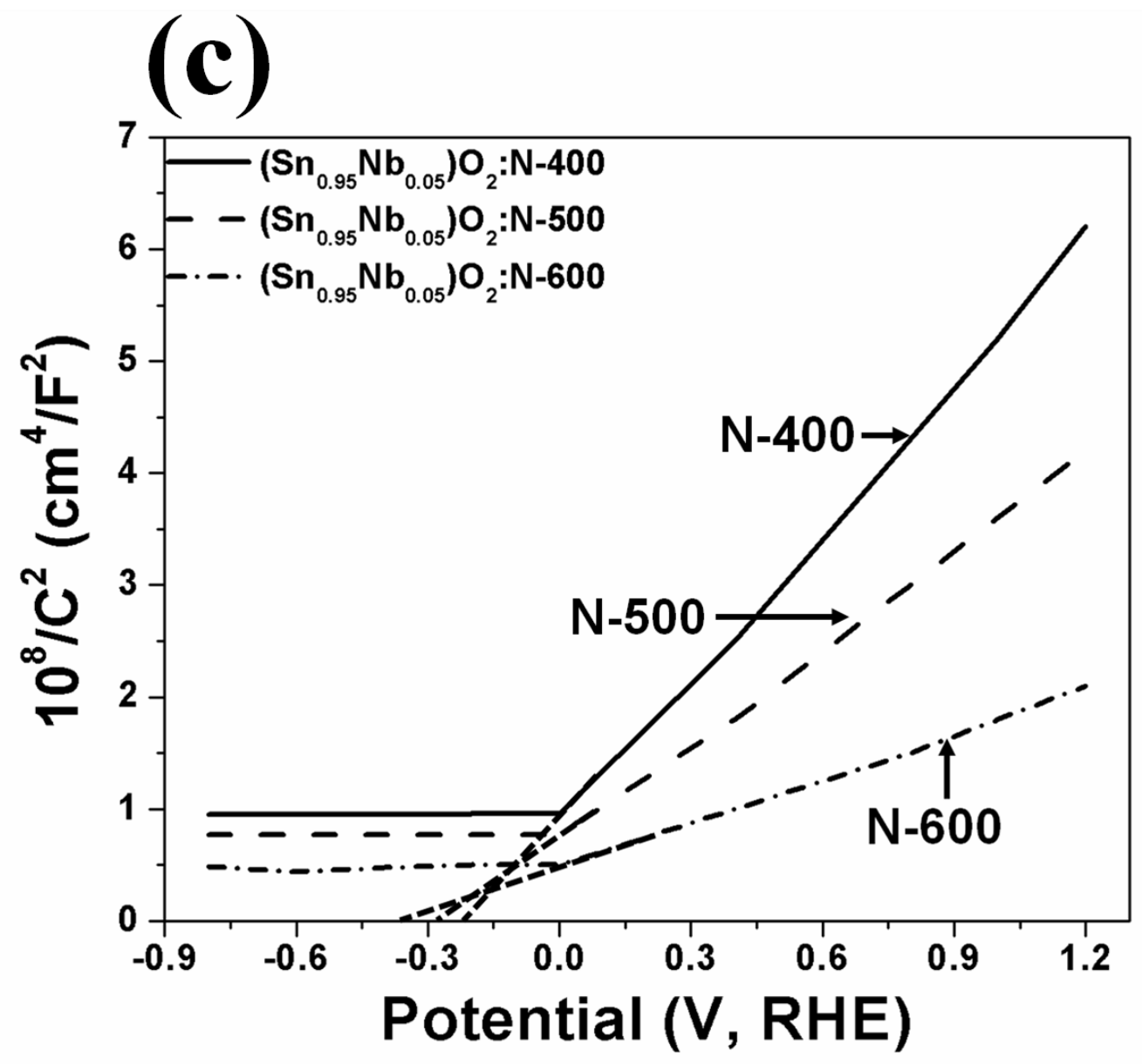

1036

1037

Figure 5c

1038

1039 


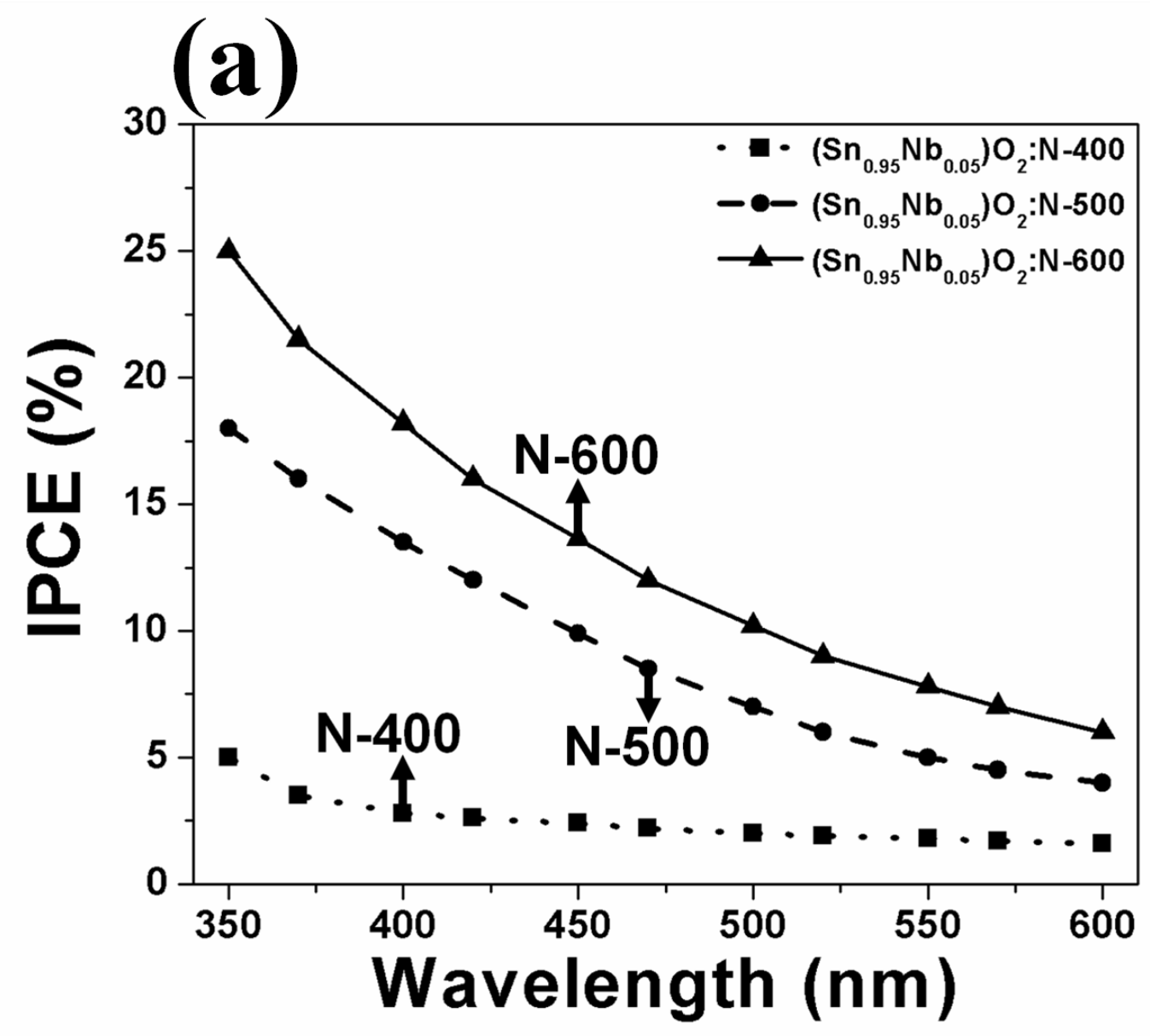

1040

1041

Figure 6a

1042

1043 


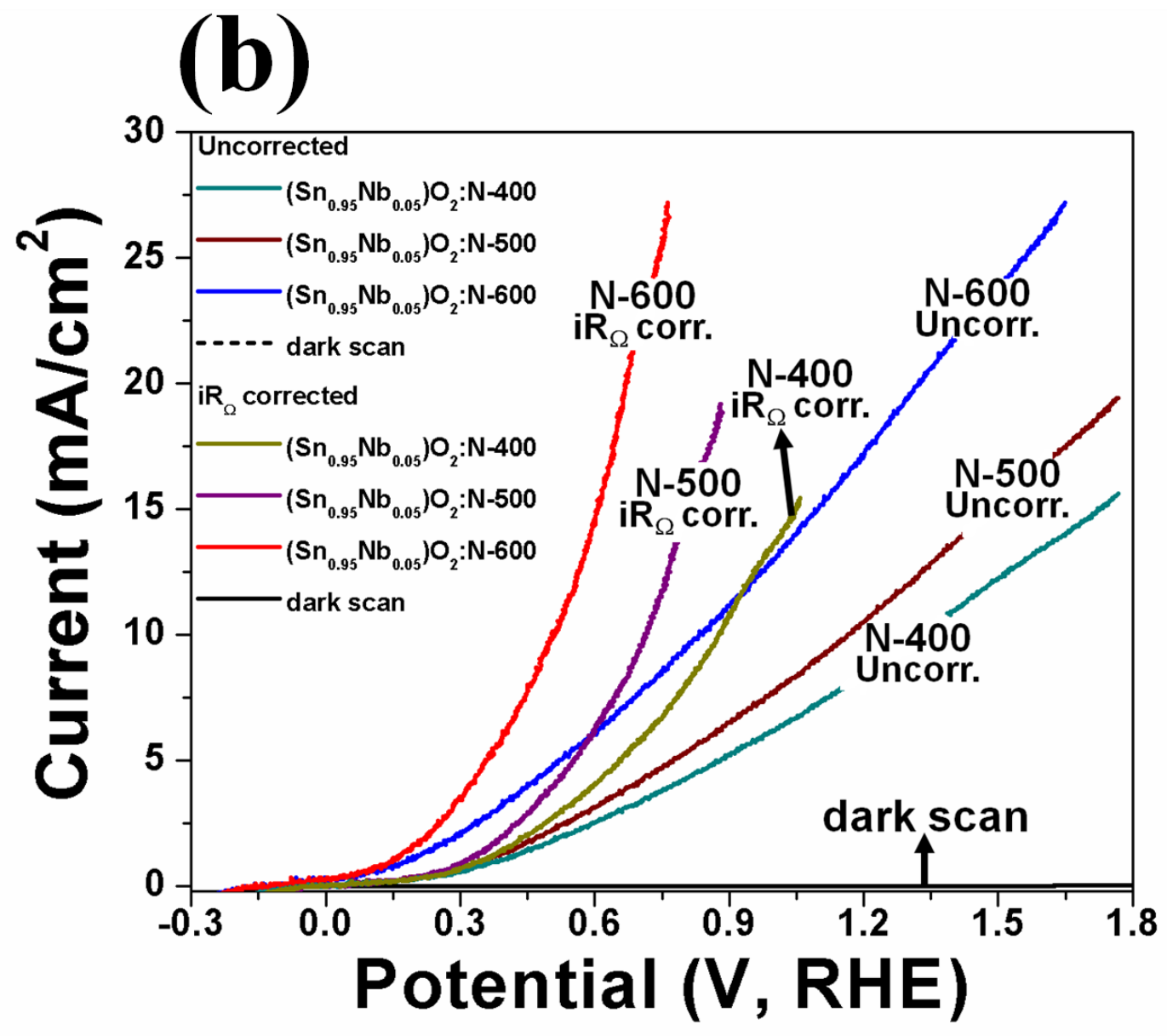

1044

1045

Figure 6b

1046

1047 


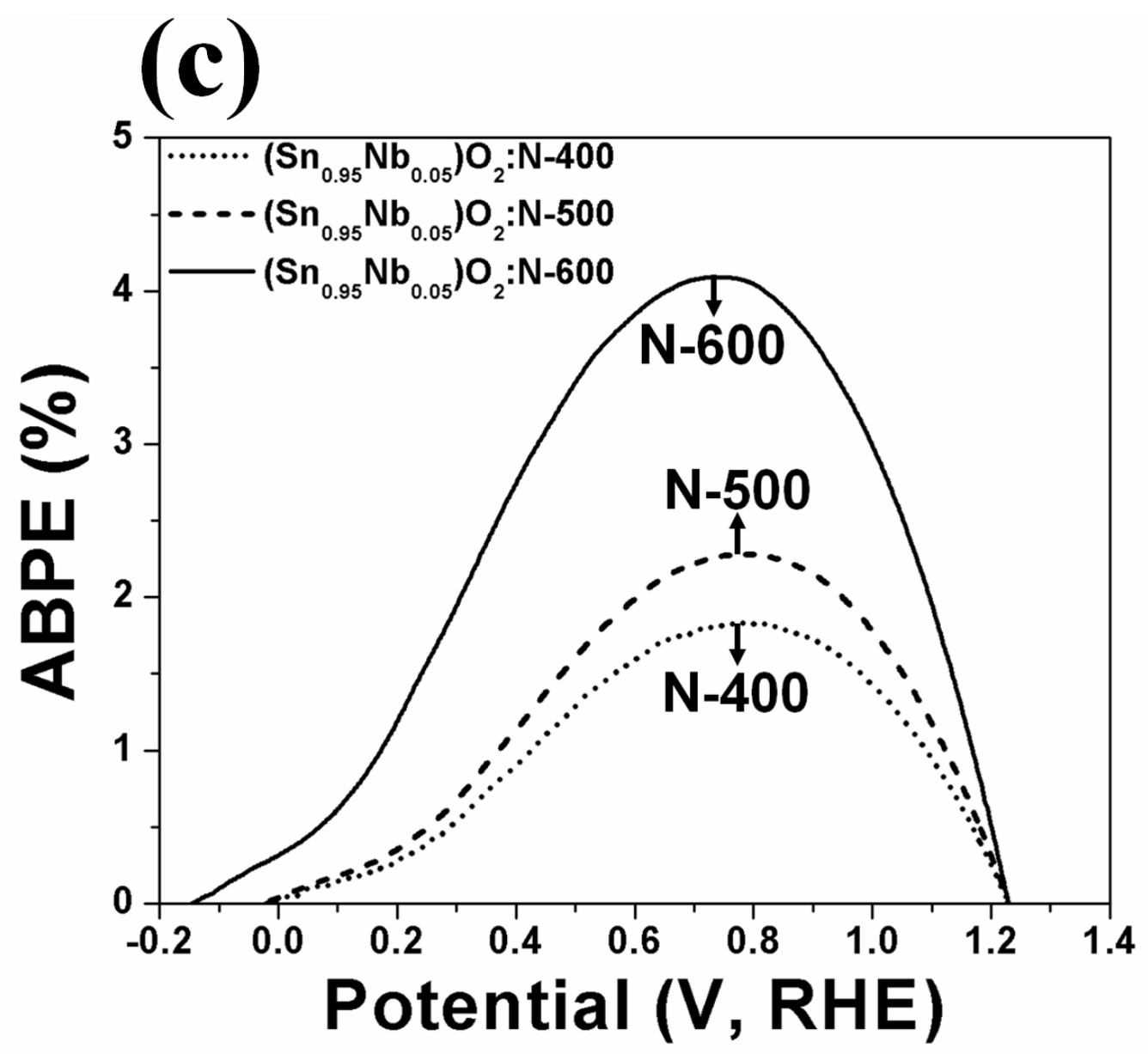

1048

1049

1050

Figure 6c

1051

1052 


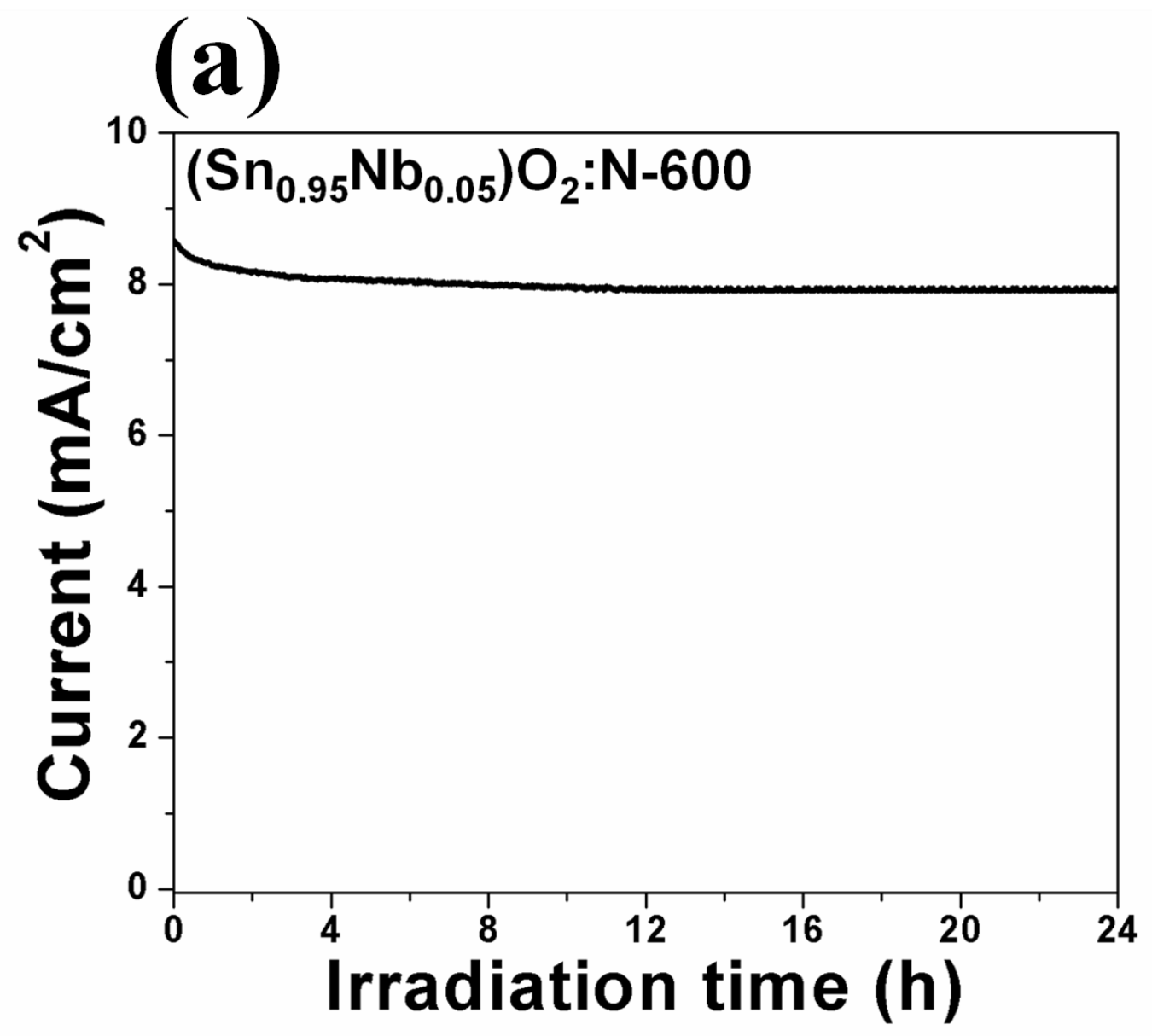

1053

1055

1056 


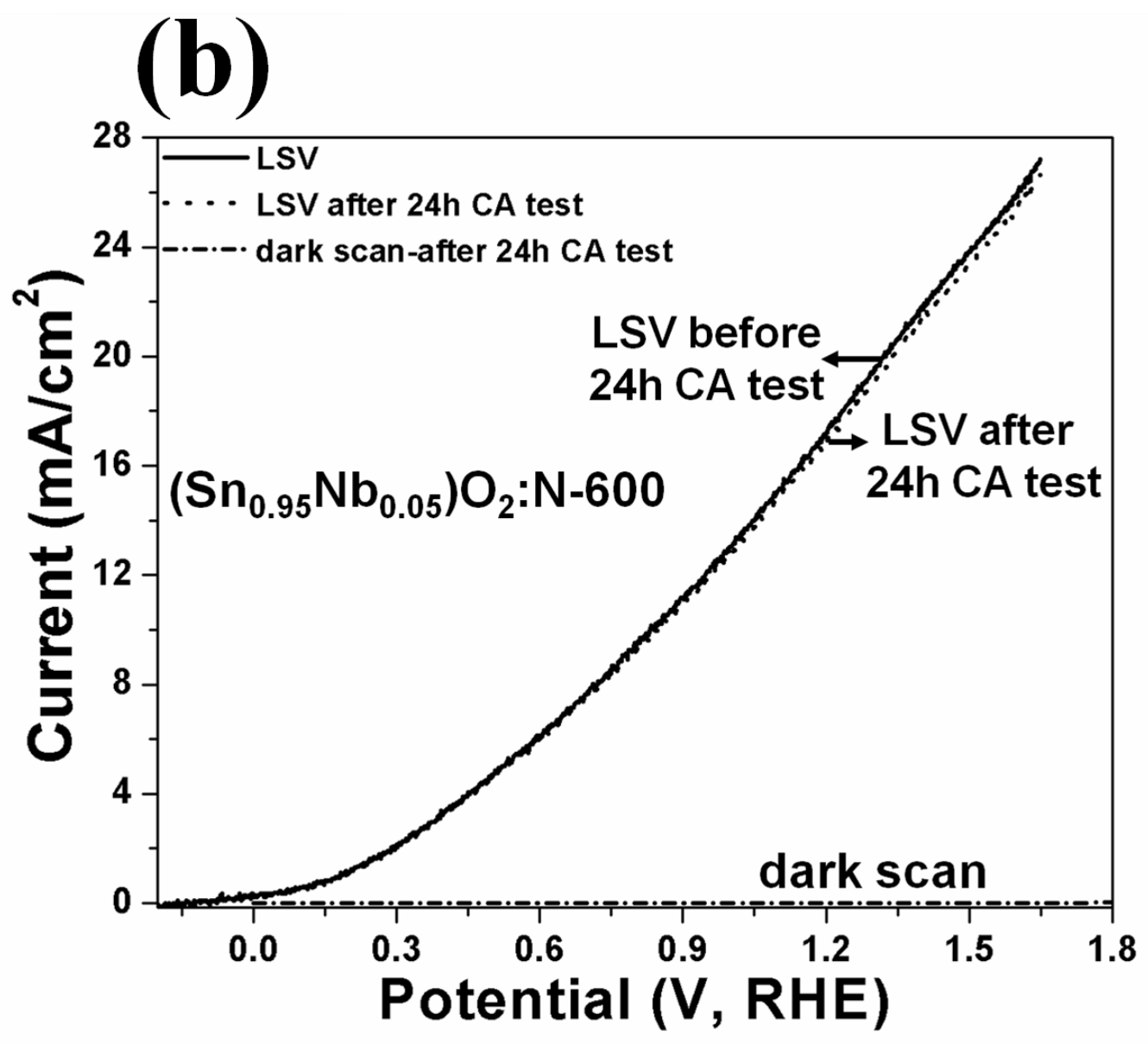

1057

1058

Figure 7b

1059

1060 

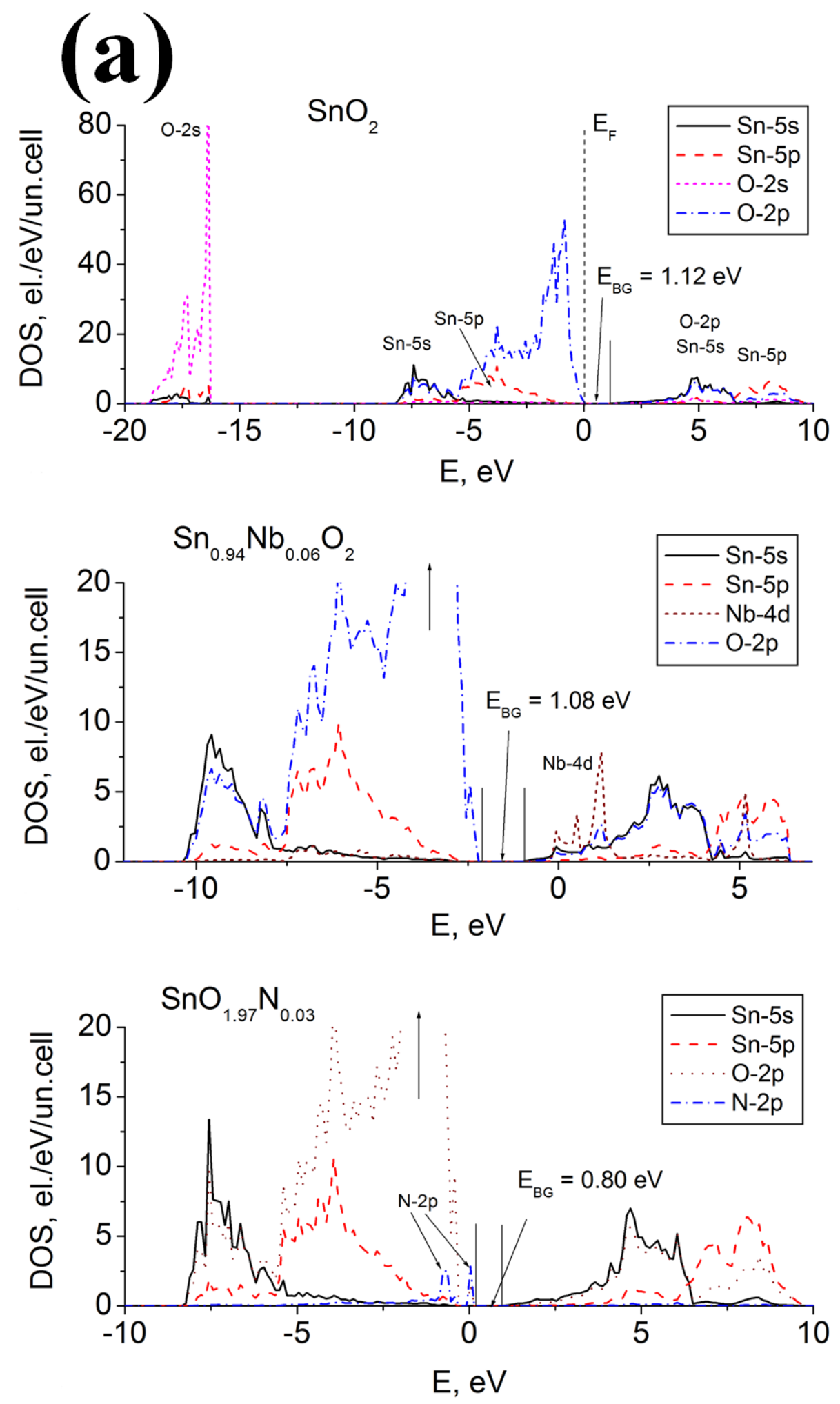

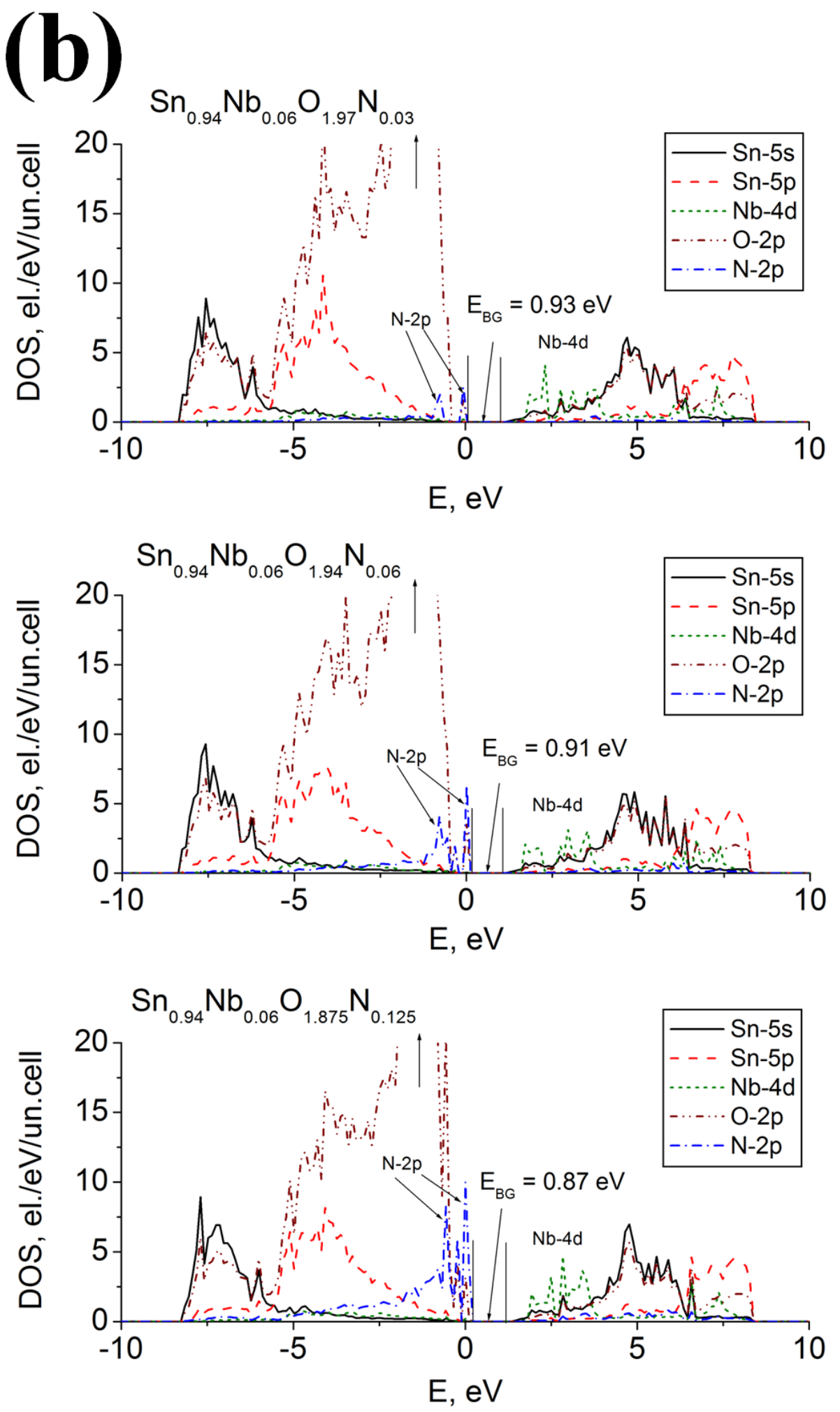


\section{Graphical abstract}

1067

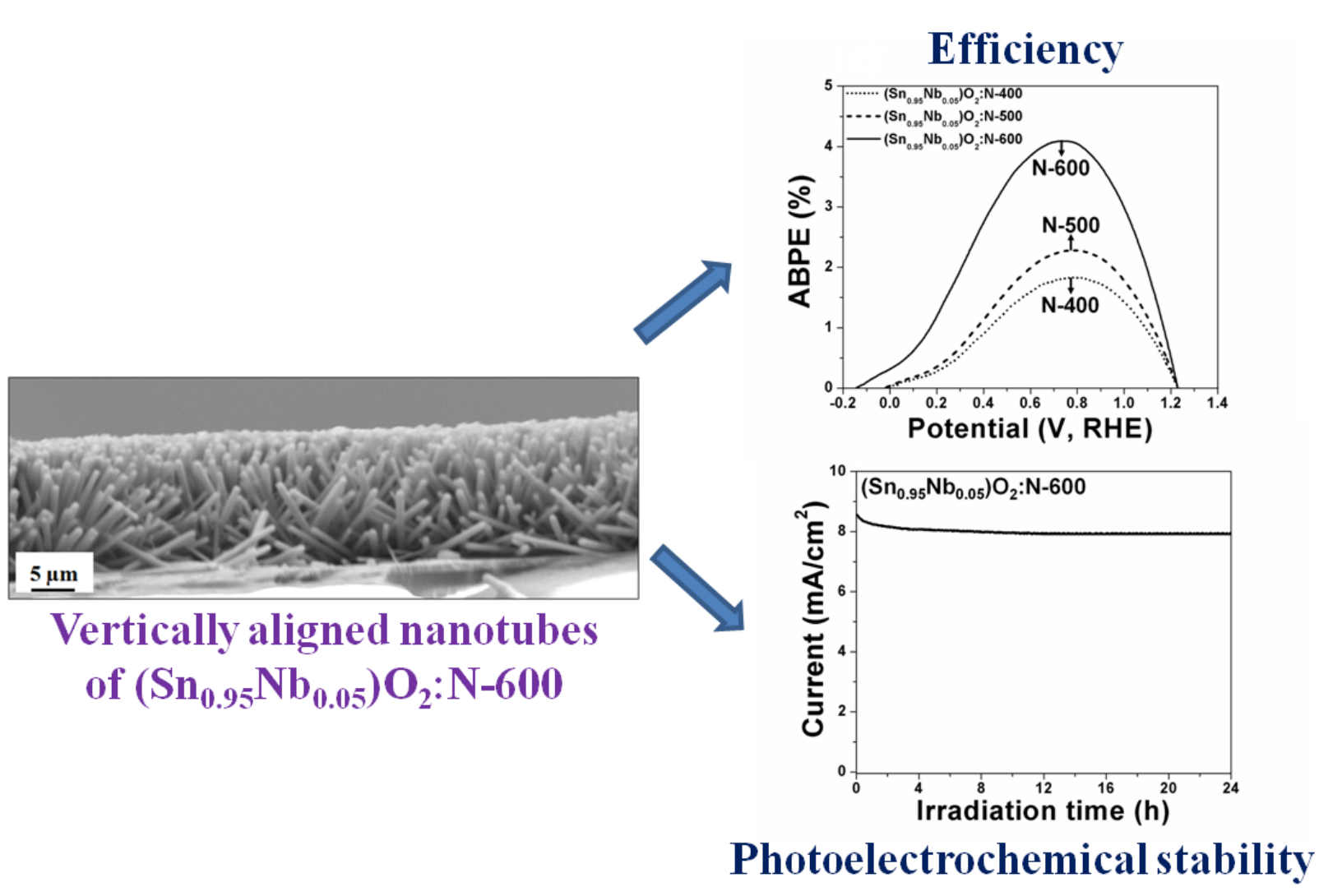

